\title{
Impactos socioeconômicos do sistema de aposentadorias rurais no Brasil e na Amazônia
}

\author{
Helmut Schwarzer \\ Doutor em Economia pela Universidade Livre de \\ Berlim e Técnico do Instituto de Pesquisa \\ Econômica e Social Aplicada (IPEA)
}

\section{Resumo}

Baseado em resultados de pesquisa de campo feita no Município de Igarapé-Açu, no Estado do Pará, Amazônia, o presente estudo agrega elementos à compreensão dos impactos do sistema brasileiro de aposentadorias rurais, verificando o peso que possuem as transferências monetárias da previdência rural no orçamento das famílias e o impacto sobre as economias locais e regionais. Ademais, analisa outras funções, além da de provisão de renda na velhice, que as aposentadorias rurais estão assumindo no seio da família e da sociedade. Procura entender que conseqüências a presença de um sistema de transferências monetárias de grande magnitude possui para a reorganização dos interesses pessoais e para a criação de comportamentos econômicos maximizadores entre os participantes da previdência rural.

\section{Palavras-Chave}

Amazônia - Aposentadorias - Seguridade
- Brasil

\section{Abstract}

Based on field research done in Igarapé-Açu, State of Pará, Amazônia, the present study joins elements to the understanding of the impacts of the rural retirement system of Brazil, verifying the weight it has in the family budget and in the local and regional economies. It analyzes other functions, besides the one of provision of income in the old age, that the rural retirements are assuming in the family and in the local society. It tries also to understand the consequences of a great system of monetary transfers for the reorganization of the personal interests and for the creation of economical maximizing behaviors among the participants of the mentioned system.

\section{Keywords}

$$
\begin{aligned}
& \text { Amazon - Retirement - Social } \\
& \text { Security - Brazil - Old Age Income }
\end{aligned}
$$




\section{Introdução}

O subsistema rural da Previdência Social brasileira parece ser, entre os casos conhecidos em países em desenvolvimento, uma exceção quanto ao significativo grau de cobertura e à alta precisão do targeting embora a focalização nos mais pobres não seja intencional, uma vez que as regras referentes ao plano de benefícios e ao modo de contribuição são universalizantes. Parece constituir assim um programa que tem uma efetividade inédita no combate à pobreza no meio rural brasileiro.

Quando se fala de impactos socioeconômicos de programas de previdência, cabe lembrar que um sistema previdenciário possui duas funções principais: 1) repor os rendimentos do segurado no período de inatividade; 2) combater a pobreza, ao evitar que idosos permaneçam sem rendimento no momento do seu ciclo de vida em que, por razões físicas e convenção social, eles já não mais devem ser expostos ao fardo do trabalho.

Para tanto, as sociedades, em todas as épocas e em todas as regiões do mundo, organizam sistemas formais ou informais, públicos, privados ou intrafamiliais, de transferência de renda intergeracionais - sempre da geração ativa para a inativa. Os sistemas formais, públicos ou privados, podem ser financiados por meio de contribuições dos segurados ativos, de impostos arrecadados junto a toda a sociedade, de rendimentos de estoques de capital investidos em nome dos segurados ou de formas mistas das alternativas anteriores. Note-se que nunca um sistema formal é introduzido em um espaço de relações "previdenciárias" vazio, sempre havendo pelo menos um sistema de proteção baseado na solidariedade intrafamilial. Da mesma forma, cabe chamar a atenção para o fato de que o encerramento de um programa previdenciário não implica o desaparecimento das transferências subjacentes, mas, em geral, acarreta mudanças em sua forma e em sua fonte de financiamento.

Ao organizar-se tais transferências intergeracionais desejadas, podem ocorrer também outras transferências não previstas, se eventualmente os financiadores das transferências estiverem localizados em uma região geográfica e os beneficiários em outra - ou se os receptores e os pagadores forem de camadas sociais diferenciadas. No caso do sistema de previdência brasileiro (tanto o rural, quanto o geral), há, conforme estudos já divulgados, uma forte transferência inter-regional de renda com significativos impactos sobre a dinâmica econômica dos municípios beneficiados. Também parece haver elementos de redistribuição progressiva interpessoal de renda por meio do sistema previdenciário rural. Cumpre chamar a atenção para o fato de que essa redistribuição, com efeito positivo, vai em sentido contrário à amplamente conhecida redistribuição interpessoal de renda regressiva engendrada nos planos de benefícios urbanos, em que as aposentadorias por tempo de serviço têm representado uma transferência dos mais aos relativamente menos necessitados. 
O problema fundamental enfrentado pelos mais diversos países, quando se trata de previdência social para o setor rural, reside no fato de que o modelo tradicional de previdência - o bismarckiano, baseado em contribuições do segurado sobre seu rendimento para o financiamento do esquema e para a determinação do acesso aos benefícios - foi desenhado em primeira linha para trabalhadores urbanos, primordialmente industriais, com emprego assalariado formal e rendimentos regulares. A realidade rural, no entanto, apresenta rendimentos em periodicidades diferentes daquelas exigidas pelos esquemas tradicionais de previdência, com irregularidade de fluxos monetários, formas diferenciadas de ocupação (posse, pequena propriedade com agricultura familiar, assalariamento, trabalho volante, parceria, arrendamento, etc. $)^{1}$ e, em especial no caso da América Latina, uma subordinação da dinâmica agrícola ao restante da dinâmica urbano-industrial dentro do modelo de desenvolvimento adotado nas décadas passadas, que, além de financiar investimentos com transferências de recursos do setor agropecuário ao industrial, deixou uma vasta extensão de agricultores familiares excluídos, desvinculados da ou apenas parcialmente integrados à economia monetária. Desta forma, a capacidade contributiva do setor rural para um sistema de previdência baseada no modelo bismarckiano é extremamente limitada - o que se reflete em um histórico de baixíssimas taxas de cobertura previdenciária entre a população ocupada na agricultura na média latinoamericana (vide Mesa-Lago, 1994). A experiência internacional e mesmo a experiência brasileira parecem indicar, a necessidade de estruturas de financiamento mistas e alternativas à contribuição, a fim de universalizar a cobertura e oferecer, em geral, benefícios em um patamar básico, dentro da capacidade de financiamento de cada país, uma vez que subsídios são necessários.

O presente estudo tem como finalidade agregar elementos à compreensão dos impactos do sistema de previdência rural brasileiro, organizado em princípios distintos daqueles do modelo bismarckiano, sobre a sociedade e a economia regional e local no Brasil. Pretende-se verificar que peso possuem as transferências monetárias via previdência rural no orçamento das famílias e obter indícios quanto a impactos sobre as economias locais e regionais no Estado do Pará. Quer-se estudar que funções, além da de provisão de renda na velhice, as aposentadorias rurais porventura estão assumindo no tecido familiar e social. Procura-se entender que conseqüências a presença de um sistema de transferências monetárias de grande magnitude possui para a reorganização dos interesses pessoais e para a criação de comportamentos econômicos maximizadores de determinados agentes participantes da arena da previdência rural. É preciso ressaltar, entretanto, que as conclusões extraídas dos dados a serem apresentados neste trabalho referem-se

\footnotetext{
No Brasil em geral e nos Estados da Região Norte em particular, predominam amplamente as formas de ocupação "propriedade" e "posse", conforme os Censos Agropecuários do IBGE.
} 
basicamente ao Estado do Pará e ao Município de Igarapé-Açu (PA), onde foi feita a pesquisa de campo. Elas somente poderiam ser generalizadas após cuidadosa comparação com resultados de pesquisas similares realizadas em outras regiões do país.

O trabalho estrutura-se em sete partes. Após a introdução, há uma breve resenha de algumas experiências internacionais com sistemas de previdência rural. A seguir, na terceira parte, relata-se a evolução históricolegal do sistema brasileiro de Previdência para os trabalhadores do campo. A próxima parte contém, primeiro, uma breve descrição quantitativa do sistema previdenciário rural no Brasil e no Pará, para, num segundo segmento, discutir impactos diferenciados das transferências por meio de benefícios rurais por município no Estado do Pará. No quinto capítulo do texto, relatase a pesquisa de campo, efetuada no município de Igarapé-Açu (PA), com a realização de entrevistas com beneficiários da Previdência rural, versando sobre os impactos da percepção do benefício no microcosmo da unidade familiar e/ou domiciliar. Por fim, na sexta parte, levantam-se, a partir de declarações e entrevistas realizadas também em Igarapé-Açu, Castanhal e Belém (todos no Estado do Pará), assim como em Brasília, ao longo de 1998, alguns elementos para uma economia política das aposentadorias rurais, ou seja: um princípio de mapeamento de teias de interesses pessoais e institucionais desenvolvidos pelos vários atores participantes da arena da Previdência Rural. Logo a seguir, conclui-se com algumas considerações relativas às aposentadorias rurais e reforma da Previdência Social, em curso no Brasil de 1995-98 (fase I), e sua regulamentação (fase II, em planejamento em 1999).

\section{Sistemas de aposentadorias ou benefícios rurais na Alemanha, Polônia, Equador, México, Costa Rica e Argentina}

Na Europa e, em especial, na Alemanha, sistemas de aposentadorias rurais têm sido classicamente defendidos e subsidiados com base no argumento de que, por seu intermédio, facilita-se o traspasso da responsabilidade da unidade produtiva rural aos jovens, criando-se fortes incentivos para a modernização tecnológica do agro. Na Seguridade Social da Alemanha ${ }^{2}$ há, desde 1995, um subsistema de "Seguro Social Rural" (Alterssicherung der Landwirte), que substituiu o antigo "Sistema de Auxílio Social Rural" (Altershilfe für Landwirte) existente desde 1957. O novo sistema rural oferece prestações mais limitadas que o seguro social geral, partindo do pressuposto de que o agricultor é um pequeno empresário autônomo, que fará um planejamento de formas complementares de renda na velhice, mais adequadas ao seu estilo de vida rural (via propriedade, filhos, poupança, etc.). Na Alemanha, existe a possibilidade de ser afiliado dos dois seguros sociais - rural e geral se houver dupla atividade profissional (uma rural, outra urbana). Não há, no

2 Vide BMELF (1998) para maiores informações sobre o sistema previdenciário rural na Alemanha. 
entanto, a possibilidade de somar tempos de contribuição dos dois sistemas para a obtenção de um único benefício, nem existe, em função disso, a necessidade de compensação financeira entre ambos os módulos. Ao participar de um subsistema, o assegurado tem suas contribuições registradas em seu nome e, mesmo que ele não mais contribua para o sistema rural por algum tempo, a volta ao subsistema sempre é permitida. Da mesma forma, o conjunto mínimo de contribuições exigido para a qualificação às aposentadorias e demais benefícios não precisa necessariamente ser contíguo no tempo, podendo haver tempos de não-contribuição de duração variável. A perda da condição de segurado no subsistema rural nunca é definitiva, ao contrário de certas situações de desligamento de segurados do seguro social geral.

Contribuintes obrigatórios do sistema são o agricultor proprietário de estabelecimento rural, seu cônjuge e outros membros trabalhadores nãoremunerados da família, que trabalhem principalmente no estabelecimento rural. A faixa de idade de filiação compulsória ao seguro rural vai de 18 a 65 anos. Todos são tratados como se fossem segurados autônomos. A contribuição mensal pessoal é de valor unitário e estava em DM 328 em 19973. Para famílias de agricultores mais pobres há um "desconto" de até 80\% do valor da contribuição, conforme faixas de renda preestabelecidas. Cerca de 2/3 dos agricultores segurados usufruía de algum desconto sobre a contribuição mensal em 1997.

O elenco de benefícios monetários básicos oferecidos consiste em aposentadoria por idade, por invalidez ou incapacidade profissional, bem como pensão de sobrevivente. Além disso, há todo um leque de outros benefícios monetários e não-monetários (seguro-saúde, licença-maternidade, auxílio-doença, seguro-acidente, etc.), que não serão analisados aqui.

A idade para aposentar-se é de 65 anos, com 15 anos de contribuição, para o chefe de estabelecimento. O cônjuge de um agricultor aposentado pode aposentar-se com pelo menos 55 anos de idade e 15 de contribuição, sofrendo, no entanto, abatimentos no valor do benefício de acordo com os anos de antecipação à idade regular de 65 anos. O valor do benefício é obtido de acordo com uma fórmula de cálculo, que contém, entre outros, o número de contribuições efetuadas. O valor médio dos benefícios, no entanto, é inferior ao do seguro social geral.

O financiamento do subsistema de seguro social rural na Alemanha depende crucialmente de subvenções do Estado. Em 1997, de um gasto total de cerca de DM 6 bilhões em benefícios, DM 4,2 bilhões (76\%) correspondiam a contribuições do Estado e apenas DM 1,8 bilhão (24\%) era resultado de contribuições dos segurados. O sistema é deficitário desde 1962, com o que a idéia original, dos anos 50, de que um subsistema previdenciário rural poderia ser autofinanciável, revelou-se ilusória.

3 A taxa de câmbio era de aproximadamente US\$ 1,00 (um dólar norte-americano) para DM 1,70 (um marco alemão e setenta pfennig) em 1997. 
Na Polônia ${ }^{4}$ também existe, desde 1990, um subsistema específico de proteção social aos agricultores, conhecido pela sigla KRUS. No subsistema KRUS, oferecem-se aposentadorias por idade, invalidez e pensões, bem como prestações por acidente de trabalho, doença e maternidade. Agricultores que cultivem uma área muito reduzida não são segurados compulsórios. Para ter acesso a uma aposentadoria por idade aos 65 (homens) e 60 anos (mulheres), há a necessidade de ter contribuído por 25 anos. A contribuição é trimestral e igual a 30\% da aposentadoria mínima polonesa. A idade de acesso ao benefício pode ser reduzida em até 5 anos com abatimento correspondente no valor do benefício.

O benefício de aposentadoria por idade é calculado com base em uma fórmula, que inclui os anos de contribuição efetuados, os quais, ponderados, são multiplicados pelo valor da aposentadoria mínima. Com isso, os benefícios ficam em um nível mais reduzido que no seguro social comum ZUS, mas são indexados aos benefícios dos demais aposentados do país. O sistema KRUS, administrado pelo Ministério da Agricultura, pagava benefícios a aproximadamente 2 milhões de agricultores em meados dos anos 90. Quando da criação do subsistema KRUS, em princípios da atual década, planejava-se que o subsídio do Estado ao subsistema fosse da ordem de cerca de $75 \%$. Esse valor, no entanto, revelou-se insuficiente e chegou-se na metade da década a 93\% do total de gastos com benefícios financiados por meio de impostos. Sabe-se que recentemente foi decidida uma reforma estrutural do sistema previdenciário polonês, cujos impactos sobre a estrutura futura do sistema de aposentadorias rurais não são conhecidos aqui.

Na América Latina também há vários países, além do Brasil, que apresentam programas de proteção social voltados especificamente para o setor rural, mas cujo escopo é mais restrito que as duas experiências relatadas e que o programa em execução no Brasil (vide Mesa-Lago, 1993 e 1994). Por exemplo, no Equador, há o Programa del Seguro Social Campesino que, iniciado em 1973, cobre apenas trabalhadores associados em cooperativas e comunidades agrícolas, que têm que cumprir determinados critérios de estruturação institucional para serem aceitos como intermediários do programa pelo IESS. Em 1990, estavam cobertos apenas 14\% da população rural. O Programa financia-se basicamente com transferências dos segurados urbanos para os serviços prestados à população rural. O México possuía desde 1973 programa semelhante, chamado COPLAMAR, o qual oferecia principalmente serviços de saúde e apresentava ainda critérios de focalização sobre a população rural mais pobre e exigia envolvimento comunitário. No final dos anos 80, após uma fase de desmantelamento sob o ajuste estrutural póscrise da dívida externa, o programa foi transferido parcialmente aos Estados e Municípios e em parte integrado ao IMSS, com o nome de IMSS-Solidaridad. Esse último programa, de porte significativo, possui um mix de financi-

${ }_{4}^{4}$ Como fontes vide Benio/Mlynarczyk-Misiuda 1997 e Golinowska et. al. 1997. 
amento na proporção estimada de 60\%-40\% entre recursos fiscais e transferências de arrecadação de segurados urbanos. Já na Costa Rica conseguiu-se uma cobertura mais extensa da população rural, principalmente na área de serviços de saúde do seguro social, por meio de convênios da CCSS com cooperativas e outras instituições rurais. Os programas rurais da Costa Rica são financiados basicamente por meio de recursos tributários gerais. Além desses países, outros há na América Latina que estenderam de alguma forma a cobertura previdenciária ao campo. Entre eles está a Argentina, cujos primeiros passos na proteção do segmento rural datam da década de 40 e que apresenta uma aposentadoria por idade avançada para trabalhadores rurais aos 67 anos de idade (homens/mulheres) em seu plano de benefícios (vide ANSeS, s.d.-a e s.d.-b). O requisito básico para ter acesso ao benefício é comprovar que, durante no mínimo 10 anos, tenha trabalhado em atividades rurais em relação de dependência e que essa ocupação era o principal meio de vida do candidato ao benefício.

Uma lição possível de ser extraída das tentativas bem-sucedidas de expandir a cobertura ao setor rural aponta o fato de que uma relação atuarial estrita em um "Modelo Bismarckiano" é impossível de se obter caso não se queira inviabilizar a cobertura, seja em que país - "periférico" ou "desenvolvido" - for. Parece haver a necessidade geral de um significativo subsídio por recursos tributários e/ou pronunciadas transferências de recursos arrecadados de contribuintes urbanos para beneficiários rurais. Obter, portanto, em reformas efetuadas em momentos de crise fiscal, um equilíbrio entre a viabilidade financeira do subsistema rural, com o asseguramento de um subsídio suficiente originado em recursos tributários, e a manutenção do objetivo da universalização da proteção, com modos de contribuição adequados às circunstâncias e capacidades dos produtores rurais, evitando-se além do mais a assistencialização do sistema e sua apropriação pelo clientelismo, é um desafio central que se projeta na agenda de debate sobre a reforma da previdência social brasileira no final dos anos 90.

\section{Evolução histórica e marco legal das aposentadorias rurais no Brasil}

\section{Antecedentes}

Sabe-se que os antecedentes do sistema previdenciário brasileiro remontam ao final do século XVIII e ao início do século XIX, quando os primeiros planos de benefícios para oficiais da Marinha e do Exército, bem como seus dependentes, foram criados. Posteriormente, no bojo do modelo liberalexportador, ao final do século XIX e início do século XX, foram consolidados programas atendendo grupos estratégicos de funcionários públicos, bem como aqueles grupos sociais organizados fundamentais para o funcionamento regular da economia (por exemplo: ferroviários, portuários).

O marco oficial de criação de um modelo previdenciário nos moldes atuais no Brasil geralmente é considerado como sendo o ano de 1923, quando 
a Lei Elói Chaves permitiu a criação das Caixas de Aposentadorias e Pensões (CAPs), as quais foram reestruturadas ao longo dos anos 30, formando os Institutos de Aposentadorias e Pensões (Malloy, 1979). Os IAPs, já dentro de uma fase de desenvolvimento conhecida como modelo de industrialização por substituição de importações, cobriam os trabalhadores por setores de atividade (bancos, transportes, indústria, etc.). No entanto, embora a Constituição de 1934 estabelecesse que todo trabalhador brasileiro possuía direito à proteção da Previdência Social (Malloy, 1976), não houve a extensão da proteção social aos trabalhadores rurais. Embora a população rural constituísse a maioria da população brasileira até a década de 60 (vide Tabela 1), entre os vários motivos que poderiam ser suscitados para explicar o fato, o principal parece ser que os trabalhadores rurais, não representavam grupo de pressão com capacidade de articulação política e vocalização suficiente para que o Estado populista-paternalista neles visse um grupo social a ser integrado por meio da expansão significativa da cobertura de programas sociais. Esse padrão de expansão da cobertura previdenciária, em círculos concêntricos desde o núcleo funcionalmente estratégico aos respectivos modelos de desenvolvimento, relegando os pouco articulados setores rurais e de serviços urbanos informais, é uma característica geral da expansão histórica da Previdência social em praticamente todos os países da América Latina (Mesa-Lago, 1978).

Tabela 1- Brasil: População urbana e rural - 1940-1996

\begin{tabular}{|rrr|}
\hline & População urbana & População rural \\
\hline 1940 & 12.880 .182 & 28.356 .133 \\
1950 & 18.782 .891 & 33.161 .506 \\
1960 & 31.303 .034 & 38.767 .423 \\
1970 & 52.084 .984 & 41.054 .053 \\
1980 & 80.436 .409 & 38.566 .297 \\
1991 & 110.990 .990 & 35.834 .485 \\
1996 & 123.082 .167 & 33.997 .406 \\
\hline
\end{tabular}

Fonte: Anuário Estatístico do Brasil 1996 e Contagem Populacional 1996.

Esse cenário começa a mudar, no caso brasileiro, a partir do início dos anos 60, quando no setor rural surgiram as "Ligas Camponesas" e foram manifestadas reivindicações socioeconômicas, entre as quais a de uma reforma agrária. O governo João Goulart reagiu a essas pressões, entre outras formas, por meio do sancionamento da Lei 4214, em 1963, que ficou conhecida como o Estatuto do Trabalhador Rural. Uma das medidas previstas foi a criação do Fundo de Assistência e Previdência do Trabalhador Rural (FUNRURAL), apresentando-se um plano de benefícios bastante amplo. No entanto, os autores são unânimes em afirmar que o plano de custeio, baseado princi- 
palmente em uma contribuição de 1\% sobre o valor da primeira comercialização do produto rural e com recolhimento de obrigação legal do próprio produtor agrícola, não forneceu uma base financeira suficiente à execução do programa, tornando, ademais, a fiscalização e o recolhimento das contribuições absolutamente inviáveis (Malloy, 1976; Oliveira, Bevilaqua s.d.). Afora isso, a administração dos benefícios e a arrecadação das contribuições do FUNRURAL foram repassadas ao IAP dos Industriários (IAPI), o qual, embora eficiente quanto ao cumprimento do seu papel em relação aos trabalhadores industriais, certamente não possuía o mesmo conjunto de incentivos para a gestão do programa rural. Desse modo, a legislação de 1963 foi, na realidade, uma medida de efeitos meramente demonstrativos, sem impacto relevante na estruturação de um sistema de proteção social na área rural.

\section{O PRORURAL/FUNRURAL (1967-1971)}

Curiosamente foi o regime militar brasileiro, conservador e autoritário (1964-1984), quem expandiu, de forma inédita na América Latina, a cobertura do sistema previdenciário ao setor rural. Malloy (1976) enumera cinco razões principais para esse comportamento aparentemente paradoxal. Primeiro, os tecnocratas encarregados da administração do sistema previdenciário identificavam-se em larga medida com o mainstream da discussão previdenciária internacional à época, o qual, orientado por princípios da OIT, via na universalização da cobertura um objetivo a ser atingido. Segundo, o temor do regime autoritário em relação a perturbações sociais na área rural - ainda mais que os anos 60 e 70 viram uma política de modernização do setor rural, marcada pela mecanização e quimificação das técnicas de cultivo, expansão da grande propriedade e produção de commodities exportáveis, uma reestruturação que significou um alto custo social para a pequena produção rural. Terceiro, a possibilidade de, por meio de um programa social de cunho paternalista e centralmente administrado, aumentar a dependência individual em relação ao Estado e cooptar organizações sociais tais como os sindicatos de trabalhadores ou empregadores rurais ${ }^{6}$. Quarto, há a menção em Malloy a declarações de técnicos governamentais da época, que desejavam evitar a intensificação da migração rural-urbana ao disponibilizar no campo uma infra-estrutura de assistência médica e benefícios monetários, mesmo que precariamente. Por último, o motivo considerado mais importante por Malloy é o papel desempenhado pela doutrina de segurança nacional do governo militar, o qual intencionava, com um programa de integração do setor rural ao projeto de desenvolvimento nacional, manter a "paz social" com a criação de "justiça social".

\footnotetext{
Este segmento do trabalho utiliza como fontes principais Oliveira G Bevilaqua (s.d)., Malloy (1976, 1979), Malloy/Parodi (1993) e MPAS/INSS/DATAPREV (1998) (SISLEX).

${ }^{6}$ Conforme Malloy G Parodi 1993: "The horizontal expansion of previdencia social [in the 1960s and 1970s] happened in the context of an authoritarian regime with a decided predisposition to emphasizing a top-down flow, not of ,social rights ' of citizenship, but of economic privileges to offset or contain effective articulation of civil and political rights of citizenship".
} 
Concretamente, o regime militar fez uma primeira alteração significativa da legislação por meio do Decreto-Lei 276/1967, o qual reduziu os benefícios previstos basicamente à assistência médica, responsabilizou o adquirente pelo recolhimento da contribuição e repassou a administração do sistema ao Instituto Nacional de Previdência Social (INPS), criado em 1966. Posteriormente, o Decreto-Lei 564/1969 criou o Plano Básico da Previdência Social, restabelecendo um elenco de benefícios monetários, no entanto, ainda não sustentável financeiramente. Por fim, o passo que marca a viabilização do sistema rural é a Lei Complementar $n^{\circ} 11$, de 1971, que criou, no lugar dos programas anteriores, o Programa de Assistência ao Trabalhador Rural (PRORURAL), cuja administração ficou ao encargo do FUNRURAL.

O PRORURAL/FUNRURAL cobriu os trabalhadores rurais, pescadores (a partir de 1972) e garimpeiros (a partir de 1975), bem como seus dependentes, oferecendo como benefícios a aposentadoria por idade aos 65 anos, a aposentadoria por invalidez, a pensão para viúvas e órfãos, o auxílio-funeral e a assistência médica. A percepção de aposentadoria por idade ou invalidez era devida apenas ao chefe de família e perfazia um valor de meio salário mínimo; a pensão equivalia a 30\%. A partir de 1974/75, foi incluída no plano de benefícios a Renda Mensal Vitalícia para idosos a partir dos 70 anos de idade ou por invalidez para os que não completassem os requisitos estabelecidos para a aposentadoria/pensão, também no valor de meio salário mínimo, bem como o seguro de acidentes de trabalho rural. A assistência médica era administrada via convênios com organizações locais, em especial via sindicatos rurais, os quais estavam explicitamente previstos como parceiros do FUNRURAL na Lei $n^{\circ} 11 / 1971$ (Art. 28) ${ }^{7}$.

O financiamento dos benefícios era feito com uma contribuição de 2,0\% sobre o valor de comercialização da produção rural, a cargo do adquirente. Além disso, uma alíquota de 2,4\% sobre a folha de salários urbana complementava a estrutura de custeio do FUNRURAL. Em 1973, um ano após a vigência da legislação, já havia mais de 800.000 benefícios mensais sendo prestados. Em fins dos anos 70, esse número já havia praticamente triplicado. A administração financeira do programa foi marcada por extrema cautela, com a geração de superávits nos anos iniciais e, ainda que no início dos anos 80 tenham sido verificados déficits, estes eram de proporção compara-

\footnotetext{
Principalmente os Sindicatos dos Trabalhadores Rurais, os quais recebiam repasses de recursos para o fornecimento de assistência médica, acabaram por se tornar agências de prestação de serviços mais que entidades representativas clássicas de interesses. Como o regulamento do FUNRURAL previa que os repasses seriam de recursos de montante fixo, ao passo que o atendimento era direcionado sem mecanismos de racionamento dos serviços para uma população carente, o programa de atendimento médico do FUNRURAL não interessou ao setor empresarial médico, pois as possibilidades de lucro eram extremamente reduzidas. Ao proibir o próprio FUNRURAL de produzir os serviços médicos, obrigando-o a fazer convênios, pode-se dizer que o regulamento do FUNRURAL estava destinado desde o início a cooptar os STRs. A fundação de um STR tornou-se, por outro lado, extremamente atrativa. No período 1971-1980 houve o maior número de novas fundações de Sindicatos de Trabalhadores Rurais na história brasileira: 1.209 novos STRs; (IBGE, 1996).
} 
tivamente pequena. Em 1977, com a criação do Sistema Nacional de Previdência e Assistência Social (SINPAS), o programa de benefícios monetários passou a ser administrado novamente pelo INPS, os benefícios médicos, pelo recém-criado Instituto Nacional de Assistência Médica da Previdência Social (INAMPS) e a instituição administrativa FUNRURAL foi extinta, embora a denominação continue sendo coloquialmente usada até hoje na área rural do Brasil para caracterizar o sistema de aposentadorias no campo, o que pode ser tomado como um indicador da grande popularidade que o programa alcançou.

Salienta-se, conforme Malloy (1976), como elemento inovador do PRORURAL/FUNRURAL, que ele representou um duplo rompimento com os princípios do seguro social de padrão contributivo bismarckiano, que caracterizaram a história da Previdência Social na América Latina no século XX. Em primeiro lugar, houve a ruptura com a noção de que a um benefício deve corresponder uma contribuição e, segundo, rompeu-se com a nação de que o benefício resultante deve estar vinculado ao padrão de rendimentos pregressos do segurado. Outro elemento diferenciador consiste no fato de que há, no programa, uma redistribuição de renda no sentido urbano-rural, contra-arrestando, ao menos parcialmente, o subsídio rural-urbano implícito na forma de financiamento dos sistemas urbanos via contribuição sobre a folha salarial, cuja parcela patronal geralmente é repassada para os preços dos bens consumidos também na área rural (Oliveira, Bevilaqua, s.d.; Malloy, 1976).

\section{A Constituição de 1988 e a legislação complementar dos anos 90}

A promulgação da Constituição de 1988, em um contexto de transição do regime autoritário para a democracia, e sua regulamentação pelas Leis 8.212 e 8.213, em 1991, significaram uma alteração conceitual profunda para o programa previdenciário rural no Brasil ${ }^{8}$. Extinguiu-se o tratamento administrativo-institucional separado dado ao setor rural na Previdência Social, com a inclusão dos trabalhadores rurais e dos segurados em regime de produção familiar, chamados de "segurados especiais", no plano de benefícios normal do Regime Geral de Previdência Social. A primeira especificidade continuou residindo na forma de contribuição do segurado especial, em que, em vez de contribuições sobre a remuneração percebida, manteve-se a contribuição sobre a produção comercializada, cujo recolhimento é encargo do comprador (em 1998, de 2,2\% sobre o valor de venda, sendo 0,1\% destinado ao seguro de acidentes de trabalho e outro 0,1\% ao Serviço Nacional de Aprendizagem Rural-SENAR). Essa equiparação dos segurados em termos de plano de benefícios significou que, tal qual para os segurados normais do

Quanto ao contexto no qual ocorreu a Assembléia Nacional Constituinte (1987-88) e as reformas na política social vis-à-vis reformas na área econômico-fiscal, vide Dain (1988), Melo (1993) e Oliveira (1995). 
INSS, de 1992 em diante, o piso de benefícios para aposentadorias e pensões passou a ser de um salário mínimo (aplicável também aos benefícios concedidos antes de 1988) e as mulheres vieram a ter acesso à aposentadoria independentemente de ser o cônjuge já beneficiário ou não. Uma segunda especificidade de tratamento reside na redução da idade de acesso à aposentadoria por idade, que ficou fixada em 60 anos para homens e 55 anos para mulheres no meio rural (65/60 para homens/mulheres entre segurados normais). Uma terceira diferença de tratamento corresponde às formas de comprovação do tempo de atividade rural, a ser documentada na mesma extensão que o período de contribuição mínimo previsto para os segurados urbanos. A comprovação da atividade rural pode ser feita, além das possibilidades listadas para os trabalhadores urbanos, por meio da documentação comprobatória do uso da terra (contrato de parceria ou arrendamento, termo de propriedade do terreno, etc.), notas de venda da produção rural (bloco de notas do produtor rural) ou declaração expedida pelo sindicato rural, homologada pelo INSS.

Outra modificação de impacto sobre o elenco de benefícios do setor rural adveio com a Lei 8.742, de 1993, a "Lei Orgânica da Assistência Social" (LOAS). Na qual regulamentou-se a substituição da Renda Mensal Vitalícia, para a qual havia, como um dos requisitos, a realização de 12 contribuições mensais à Previdência Social, pelo Benefício de Prestação Continuada (BPC) ou amparo assistencial, de valor correspondente a um salário mínimo mensal. O BPC, nas suas modalidades idoso e pessoa portadora de deficiência (PPD), não mais distingue a clientela rural da urbana e também não prevê mais o requisito de contribuição prévia, mas a renda familiar mensal per capita do candidato ao benefício deve ser menor que 1/4 do salário mínimo. Na modalidade BPC-Idoso, a idade de acesso é de 67 anos (para homens e mulheres, caindo para 65 anos em 2000) e, na modalidade PPD, incluem-se, além da invalidez já contemplada pela RMV, também as deficiências congênitas. O BPC passou a ser concedido a partir de janeiro de 1996, é financiado por recursos orçamentários e seu pagamento é efetuado pelo INSS. O seu rápido crescimento quantitativo deu-se principalmente na modalidade PPD (vide Tabela 2), em que o fato de os critérios de concessão permitirem a inclusão na cobertura do benefício daqueles deficientes físicos e mentais congênitos, sem necessidade de contribuição prévia, incluiu um novo grupo populacional entre os beneficiários do INSS, do qual somente aos poucos o país vem tendo um retrato mais definido. 
Helmut Schwarzer

Tabela 2 - Brasil: Quantidade de benefícios de prestação continuada/ LOAS (BPC-Idoso e BPC-PPD) mantidos, 1996-1999

\begin{tabular}{|lcr|}
\hline & BPC-Idoso & BPC-PPD \\
\hline 1996 (dez.) & 40.262 & 288.443 \\
1997 (dez.) & 92.042 & 576.876 \\
1998 (dez.) & 207.031 & 641.268 \\
1999 (mar.) & 228.129 & 657.998 \\
\hline
\end{tabular}

Fonte: AEPS, Boletim Estatístico da Previdência Social. PPD: Pessoa Portadora de Deficiência.

3. Aposentadorias rurais no Brasil e no Pará - Evolução recente e papel redistributivo inter-regional e intermunicipal

Evolução recente da quantidade de aposentadorias rurais no Brasil e no Pará

Com a implementação da nova legislação referente à Previdência Rural a partir de 1992, verificou-se um pronunciado aumento do número de benefícios mantidos. Isso se deu pois as novas regras universalizaram o acesso feminino ao subsistema, além de ter sido reduzida a idade para a aposentadoria por idade de 65 (homens e mulheres) para 60/55 (homens/ mulheres).

Gráfico 1 - Brasil: Quantidade de benefícios rurais mantidos, 1980-1999

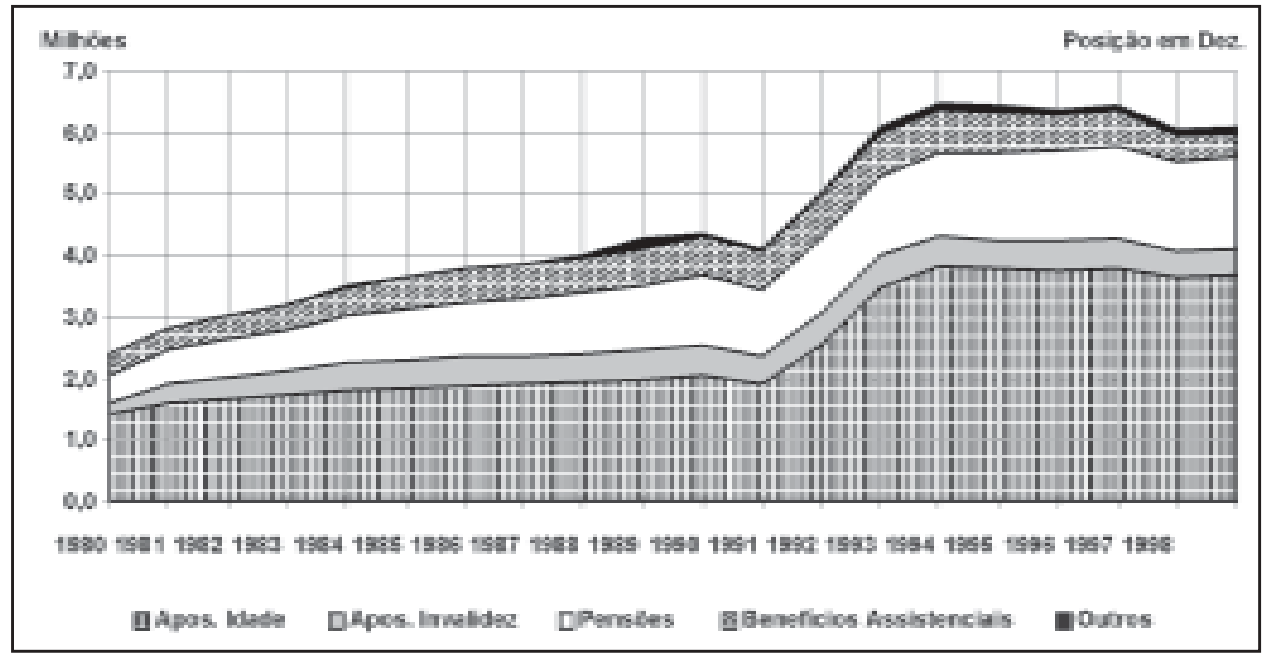

Fonte: AEPS e MPAS/CGEA, Março 1999. Nota: inclui Apos. Tempo de Serviço, Benef. Acidentários e Auxílios.

Esse salto de um total de 4,11 milhões de benefícios em 1991 para um pico de 6,48 milhões em 1994, devido basicamente ao incremento do estoque de aposentadorias por idade, pode ser claramente visualizado no Gráfi- 
co 1. A quantidade de 6,48 milhões de benefícios mensais representava mais que $1 / 3$ do total de benefícios previdenciários mantidos no INSS. Desde 1994, o estoque de benefícios tem-se mantido em patamar constante, em que a maturação demográfica da população potencialmente beneficiária pareceu estar determinando um leve aumento do número de benefícios por idade e de pensões mantidas até 1997, contrabalançado pelo gradual arrefecimento do número de benefícios assistenciais rurais não mais concedidos desde 1995 (nesse caso a estatística capta apenas Rendas Mensais Vitalícias, uma vez que os amparos assistenciais da LOAS estão contabilizados fora do subsistema rural).

A distribuição inter-regional dos benefícios rurais no Brasil está apresentada detalhadamente na Tabela 3 e no Gráfico 2. O dado sobre a população rural por Unidade da Federação, extraído da Contagem Populacional de 1996, consta para efeito de comparação, uma vez que o fato de residir em área rural (conceito censitário de rural, utilizado na Contagem) não implica necessariamente que a pessoa trabalhe em ocupação coberta pela Previdência Rural ou, vice-versa, estar ocupado em atividade coberta pela Previdência Rural não necessariamente significa que a pessoa possua sua residência em local definido pelo IBGE como sendo da área rural. Destaca-se que a Região Nordeste, que possuía 45,8 \% da população rural brasileira em 1996, é responsável por igual proporção de 45,5 \% dos benefícios. Outra região aproximadamente "equilibrada" quanto à comparação entre sua participação no total de beneficiários rurais brasileiro e na população rural total, com, respectivamente, 22,5 \% e 21,1 \%, era o Sudeste. Enquanto isso, as Regiões Norte e Sul são as que apresentam desproporções. O Sul possuía 3,6 pontos percentuais a mais de participação no total de beneficiários do que de população rural, ao passo que a Região Norte, nesse critério, era a região proporcionalmente menos beneficiada do Brasil, com uma desvantagem de quase 5,3 pontos percentuais entre ambas variáveis.

Dentro da Região Norte, o Estado do Pará tem praticamente a metade dos respectivos beneficiários rurais ou 3,6\% do total de benefícios rurais do Brasil, comparado a 7,5\% da população rural total de 1996, o que faz do Pará o Estado proporcionalmente menos beneficiado pelo subsistema rural na Região Norte e no Brasil - possivelmente devido à estrutura etária mais jovem do que a média brasileira (vide Gráfico 14 adiante). É interessante mencionar, ainda, que o número de benefícios rurais pagos a residentes no Pará (220.587) superava em 34,0 \% o de benefícios urbanos (164.582) em março de 1999. Os dispêndios totais com benefícios da clientela urbana, no entanto, eram 36,3\% mais elevados que os com beneficiários rurais no Pará no mesmo mês. Isso deve-se ao fato de que o benefício médio urbano (R\$ 237,46), principalmente em virtude do acesso mais freqüente do segurado urbano à aposentadoria por tempo de serviço, é superior ao benefício médio rural ( $\mathrm{R} \$$ 129,98; valor do salário mínimo em março de 1999: R\$ 130,00). 
Tabela 3 - Brasil: População Rural Residente, 1996, e Benefícios Rurais Emitidos, 1999, segundo as grandes regióes e as Unidades da Federação

\begin{tabular}{|c|c|c|c|c|c|c|}
\hline & \multicolumn{2}{|c|}{$\begin{array}{c}\text { População rural } \\
\text { (1996) }\end{array}$} & \multicolumn{2}{|c|}{$\begin{array}{l}\text { Benefícios rurais emitidos } \\
\text { (março 1999) }\end{array}$} & \multirow{2}{*}{$\begin{array}{l}\text { Diferencial } \\
E=D-B\end{array}$} & \multirow{2}{*}{$\begin{array}{l}\text { Proporção } \\
F=C / A^{*} 100\end{array}$} \\
\hline & $\begin{array}{c}\text { Absoluto } \\
\text { A }\end{array}$ & \begin{tabular}{l|}
$\%$ \\
$B$
\end{tabular} & $\begin{array}{c}\text { Absoluto } \\
C\end{array}$ & $\begin{array}{l}\% \\
D\end{array}$ & & \\
\hline Região Norte & 4.250 .766 & 12,50 & 441.232 & 7,24 & $-5,27$ & 10,38 \\
\hline Rondônia & 468.143 & 1,38 & 55.499 & 0,91 & $-0,47$ & 11,86 \\
\hline Acre & 168.322 & 0,50 & 22.113 & 0,36 & $-0,13$ & 13,14 \\
\hline Amazonas & 623.113 & 1,83 & 70.864 & 1,16 & $-0,67$ & 11,37 \\
\hline Roraima & 72.854 & 0,21 & 7.381 & 0,12 & $-0,09$ & 10,13 \\
\hline Pará & 2.561 .832 & 7,54 & 220.587 & 3,62 & $-3,92$ & 8,61 \\
\hline Amapá & 48.869 & 0,14 & 9.976 & 0,16 & 0,02 & 20,41 \\
\hline Tocantins & 307.633 & 0,90 & 54.812 & 0,90 & $-0,01$ & 17,82 \\
\hline Região Nordeste & 15.575 .505 & 45,81 & 2.776 .066 & 45,53 & $-0,28$ & 17,82 \\
\hline Maranhão & 2.511 .008 & 7,39 & 340.649 & 5,59 & $-1,80$ & 13,57 \\
\hline Piauí & 1.117 .061 & 3,29 & 226.406 & 3,71 & 0,43 & 20,27 \\
\hline Ceará & 2.096 .483 & 6,17 & 432.469 & 7,09 & 0,93 & 20,63 \\
\hline Rio Grande do Norte & 715.174 & 2,10 & 180.914 & 2,97 & 0,86 & 25,30 \\
\hline Paraíba & 1.043 .630 & 3,07 & 255.287 & 4,19 & 1,12 & 24,46 \\
\hline Pernambuco & 1.922 .216 & 5,65 & 405.497 & 6,65 & 1,00 & 21,10 \\
\hline Alagoas & 971.425 & 2,86 & 124.184 & 2,04 & $-0,82$ & 12,78 \\
\hline Sergipe & 483.606 & 1,42 & 86.040 & 1,41 & $-0,01$ & 17,79 \\
\hline Bahia & 4.714 .902 & 13,87 & 724.620 & 11,89 & $-1,98$ & 15,37 \\
\hline Região Sudeste & 7.177.111 & 21,11 & 1.370 .825 & 22,49 & 1,37 & 19,10 \\
\hline Minas Gerais & 3.598 .852 & 10,59 & 700.348 & 11,49 & 0,90 & 19,46 \\
\hline Espírito Santo & 626.701 & 1,84 & 118.893 & 1,95 & 0,11 & 18,97 \\
\hline Rio de Janeiro & 599.891 & 1,76 & 95.332 & 1,56 & $-0,20$ & 15,89 \\
\hline São Paulo & 2.351 .667 & 6,92 & 456.252 & 7,48 & 0,57 & 19,40 \\
\hline Região Sul & 5.358 .380 & 15,76 & 1.183.706 & 19,42 & 3,65 & 22,09 \\
\hline Paraná & 1.991 .814 & 5,86 & 472.940 & 7,76 & 1,90 & 23,74 \\
\hline Santa Catarina & 1.310 .114 & 3,85 & 226.295 & 3,71 & $-0,14$ & 17,27 \\
\hline Rio Grande do Sul & 2.056 .452 & 6,05 & 484.471 & 7,95 & 1,90 & 23,56 \\
\hline Região Centro-Oeste & 1.635 .644 & 4,81 & 324.765 & 5,33 & 0,52 & 19,86 \\
\hline Mato Grosso do Sul & 323.516 & 0,95 & 71.685 & 1,18 & 0,22 & 22,16 \\
\hline Mato Grosso & 540.284 & 1,59 & 75.499 & 1,24 & $-0,35$ & 13,97 \\
\hline Goiás & 642.146 & 1,89 & 136.351 & 2,24 & 0,35 & 21,23 \\
\hline Distrito Federal & 129.698 & 0,38 & 41.230 & 0,68 & 0,29 & 31,79 \\
\hline BRASIL & 33.997 .406 & 100,00 & 6.096 .594 & 100,00 & 0,00 & 17,93 \\
\hline
\end{tabular}

Fonte: IB GE (Contagem Populacional 1996) e Boletim Estatístico da Previdência Social (v. 4, $\left.n^{\circ} 3\right)$. 
Gráfico 2 - Brasil: Distribuição dos benefícios rurais mantidos por região, março 1999

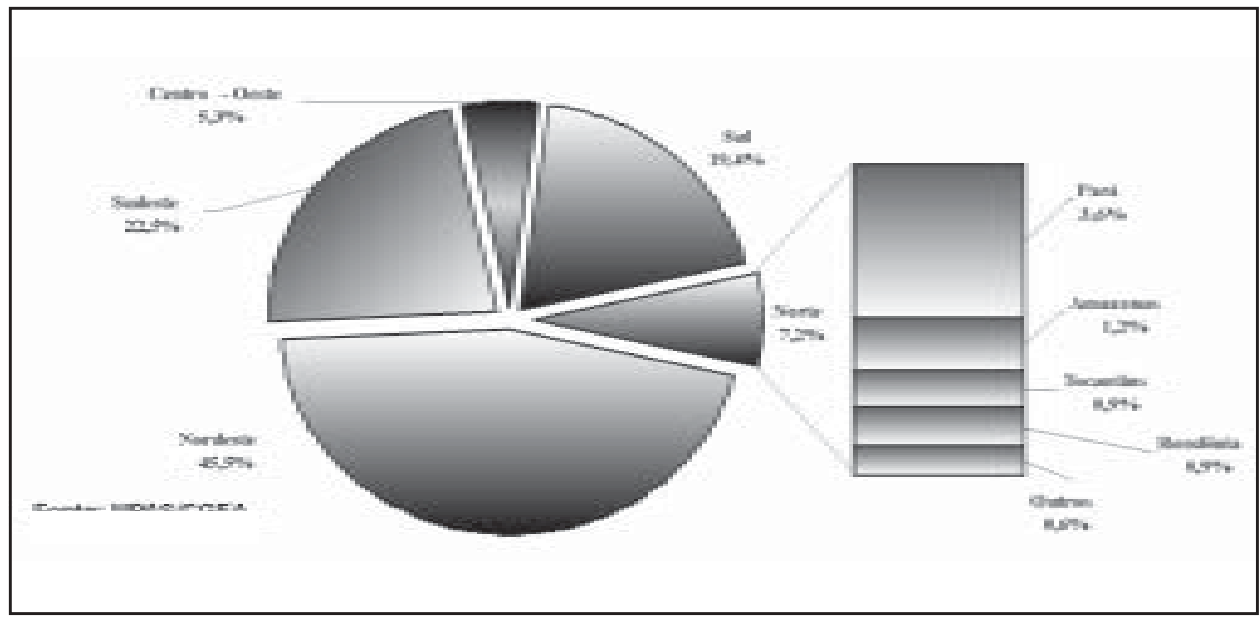

Fonte: MPAS/CGEA.

Conforme a Tabela 4, havia, em 1995, uma elevada concentração de beneficiários rurais na Região Nordeste do Pará, onde se destaca a Microrregião Bragantina, tanto em termos absolutos (37,0\% do total de benefícios rurais emitidos), quanto na relação entre beneficiários e participação da microrregião na população rural do Estado do Pará. Outra mesorregião de relevo é a Metropolitana de Belém, cujo volume elevado de beneficiários rurais (16,8 \% do total de benefícios emitidos) é amplamente explicado pela elevada proporção da população rural paraense ali residente $(28,8 \%$ na Região Metropolitana, dos quais 27,1\% na Microrregião da Capital, concentrados nos municípios de Belém e Ananindeua). O perfil da Microrregião de Castanhal, no entanto, é mais próximo do das demais microrregiões do Nordeste Paraense (com 5,2\% dos benefícios e 1,7\% da população rural).

Duas situações diferentes podem ser constatadas na análise das outras mesorregiões paraenses. Por um lado, o Baixo Amazonas apresenta participação no número de benefícios rurais emitidos levemente acima da sua participação na população total, enquanto, pelo outro, o Sul do Pará, apresentou, em função da sua trajetória de ocupação recente, um crescimento populacional mais intenso, pelo que a proporção de benefícios rurais é ligeiramente inferior à participação das duas mesorregiões Sudeste e Sudoeste Paraense na população total do Estado. 
Tabela 4 - Estado do Pará: Distribuição dos benefícios previdenciários rurais emitidos por meso- e microrregião, 1995 (em \%)

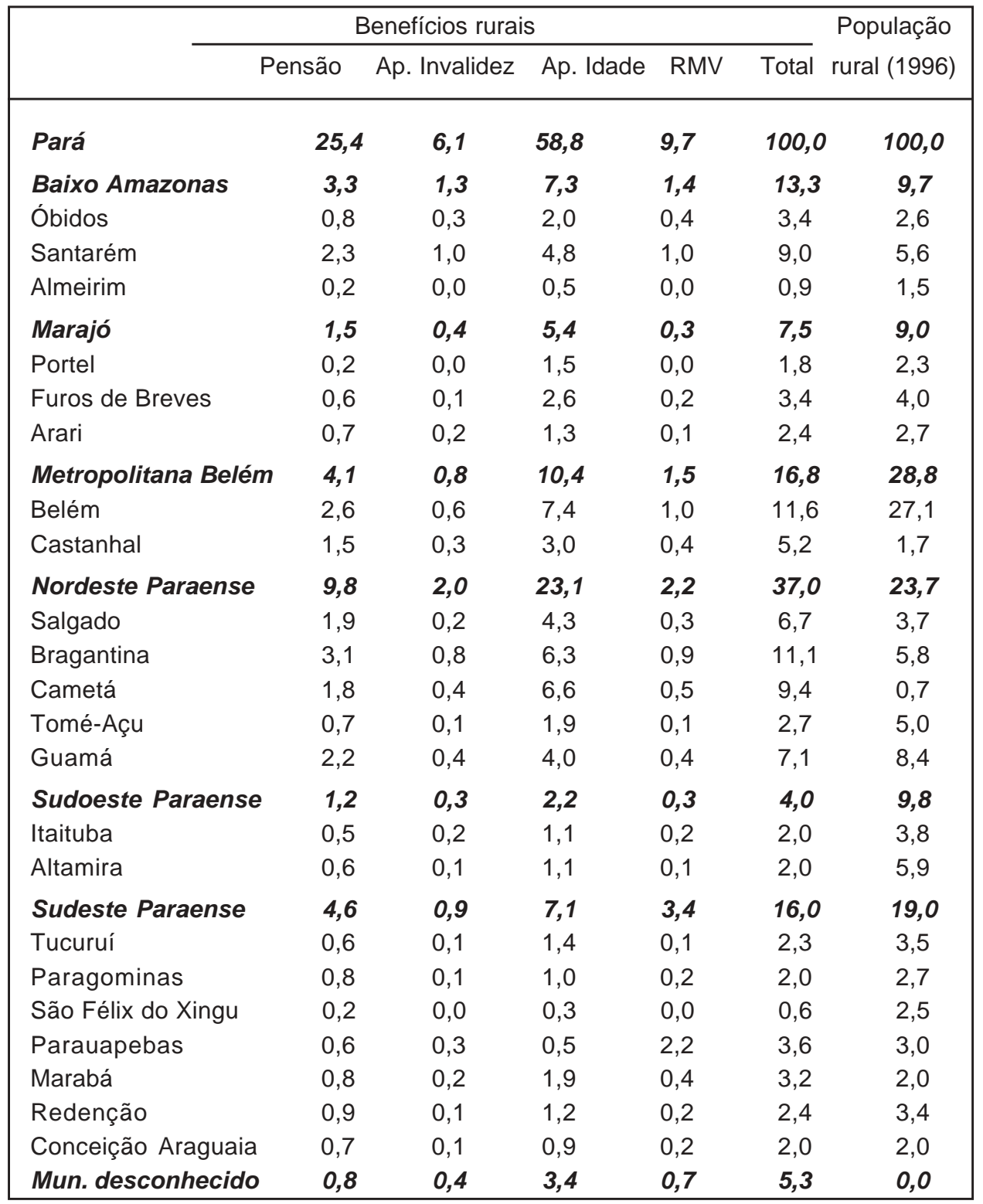

Fonte: DATAPREV/Sintese, IBGE (Contagem 1996). Elaboração própria.

Situação financeira do Subsistema da Previdência Rural e impactos redistributivos

Na Tabela 5, apresenta-se um cálculo do saldo do subsistema previdenciário rural. Note-se, incialmente, que são possíveis duas interpreta- 
ções quanto ao montante arrecadado para o financiamento da Previdência Rural. Além da soma das contribuições arrecadadas no meio rural conforme a legislação atualmente vigente, há a possibilidade de se supor a existência de uma alíquota solidária de 3 pontos percentuais dos 20 pontos contribuídos pelas empresas, o que estava previsto na legislação vigente de 1989 a 1991 (vide Delgado, 1997). No caso de uma interpretação estrita da legislação atual (pós-1991), o subsistema rural apresentou em 1997 um déficit de aproximadamente $\mathrm{R} \$$ 8,0 bilhões correntes ou 89,2\% do valor dos benefícios emitidos naquele ano. Se for considerada a segunda interpretação, o déficit é reduzido à metade, ou seja, R \$ 4,0 bilhões correntes ou 45,6\% do valor dos benefícios rurais emitidos.

Seja qual for a interpretação que venha a ser aplicada pelo observador, fica visível que o subsistema previdenciário rural no Brasil na sua atual configuração é e será dependente de ampla suplementação de recursos, seja por via de uma transferência solidária implícita dos contribuintes urbanos, como é atualmente, seja por meio de recursos do Tesouro Nacional em uma outra alternativa de financiamento. No entanto, por si, o fato de o subsistema ser deficitário não é grave, como poderia parecer inicialmente. Primeiro, viu-se que não há, na experiência internacional, conhecimento de nenhum caso de sistemas de aposentadorias voltado para o setor agropecuário que não seja deficitário. Segundo, projeções apontam uma estabilização e mesmo diminuição do déficit do subsistema no futuro (Delgado 1997), uma vez que o salto quantitativo do número de benefícios foi concluído em 1994 e é de aceitação dupla que há uma tendência à redução da população ocupada na agropecuária nas décadas vindouras. Terceiro, há uma estimativa de evasão de contribuição no setor rural muito elevada: Delgado (1997) estima que a contribuição sobre a produção agropecuária tenha sido de apenas $22 \%$ da arrecadação potencial em 1995, enquanto dos contribuintes individuais obrigatórios, em uma estimativa já mais defasada, apenas 7,6\% efetivamente estavam aportando à Previdência no setor rural em 1989 (Kageyama, Graziano, 1993). Quarto, o subsistema previdenciário rural apresenta uma série de externalidades positivas, que parecem ir muito além da proteção específica aos segurados rurais e beneficiam a sociedade brasileira em geral. A presença de externalidades positivas, na teoria econômica dos bens públicos, é justificativa para a instituição de um subsídio à respectiva atividade/programa, dado que otimiza o bem-estar de toda a coletividade e não apenas o dos beneficiários diretos do objeto de suplementação orçamentária. No transcurso da discussão da reforma previdenciária no Brasil, portanto, estes seriam aspectos a contemplar em uma avaliação mais ponderada do subsistema rural da Previdência Social, a fim de evitar pré-julgamentos baseados em raciocínios meramente fiscais e contábeis. 
Helmut Schwarzer

Tabela 5 - Brasil: Saldo financeiro do subsistema da Previdência Rural, 1997

(Em R\$1.000 correntes)

\begin{tabular}{|c|c|}
\hline Ítens & Valores \\
\hline \multicolumn{2}{|l|}{ Arrecadação rural: } \\
\hline -Contribuição do empregador rural sobre a folha salarial (Cód. FPAS604) & 172.066 \\
\hline -Contribuição de outras entidades da área rural sobre folha salarial (Cód. FPAS 787) & 96.393 \\
\hline -Contribuição de agroindústrias e cooperativas sobre folha salarial (Cód. FPAS 795) & 60.387 \\
\hline -Contribuição sobre valor de comercialização da produção rural (Cód. FPAS 744) & 636.739 \\
\hline Soma1: & 965.585 \\
\hline $\begin{array}{l}\text {-Alíquota virtual de } 3 \text { pontos percentuais do recolhimento das empresas urbanas } \\
\text { (exceto contribuições pelos códigos FPAS } 604,787,795 \text { e } 744)^{*}\end{array}$ & 3.918 .352 \\
\hline Soma2(Soma 1 + alíquota de 3pontos percentuais): & 4.883.937 \\
\hline Valor dos benefícios rurais emitidos em 1997: & 8.970 .103 \\
\hline \multicolumn{2}{|l|}{ Saldo da Previdência Rural em 1997: } \\
\hline Semalíquota de $3 \%$ do recolhimento das empresas urbanas & -8.004 .518 \\
\hline -arrecadação/benefícios emitidos (em\%) & 10,8 \\
\hline - necessidade de suplementação/benefícios emitidos (em \%) & 89,2 \\
\hline Comalíquota de $3 \%$ do recolhimento das empresas urbanas & -4.086 .166 \\
\hline -arrecadação/benefícios emitidos (em\%) & 54,4 \\
\hline -necessidade de suplementação/benefícios emitidos (em \%) & 45,6 \\
\hline
\end{tabular}

Fonte: Elaboração do autor, AEPS. * Supondo-se a continuidade da vinculação de 3 pontos percentuais da alíquota de 20 pontos percentuais da arrecadação urbana ao financiamento da Previdência Rural, conforme legislação vigente em 1989 (Lei 7.787; vide Delgado, 1997)

\section{Impactos redistributivos regionais da Previdência no Brasil}

Diversos estudos (Delgado, 1997; Maia Gomes, McDowell, 1997; Monteiro Neto, McDowell, 1998) demonstram que a Previdência Social possui, em função do desenho do seu plano de benefícios, de sua estrutura de financiamento e da profunda heterogeneidade regional brasileira, importantes efeitos redistributivos inter-regionais de renda. Esses impactos progressivos manifestam-se ao considerar-se tanto a redistribuição interestadual, quanto a redistribuição intermunicipal de renda.

Pelos dados da Tabela 6, por exemplo, é possível visualizar a existência de um viés redistributivo do Sudeste e Centro-Oeste do país para o Norte e principalmente o Nordeste, destacando-se como receptores líquidos de recursos os municípios pequenos e médios. Há que se ter presente a situação especial do Distrito Federal, onde se verifica uma movilidade importante dos aposentados retornando aos seus estados de origem. 
Tabela 6 - Brasil e regiões: Diferença entre benefícios (concedidos + mantidos) e arrecadação per capita do INSS, por classes de municípios agregados segundo a população, 1995

(em R\$/ano)

\begin{tabular}{|lcccccc|}
\hline Tamanho dos municípios & Norte & Nordeste & Sudeste & Sul & Centro-Oeste & Brasil \\
\hline Até 5.000 hab. & 18,7 & 59,8 & 13,1 & $-18,6$ & 18,2 & 15,2 \\
5.000 a 10.000 hab. & 36,3 & 82,2 & 17,6 & 26,1 & 21,9 & 41,5 \\
10.000 a 20.000 hab. & 48,5 & 104,0 & 8,1 & 1,4 & 15,5 & 51,8 \\
20.000 a 50.000 hab. & 53,5 & 130,2 & 27,1 & 83,1 & 72,8 & 82,9 \\
50.000 a 100.000 hab. & 42,4 & 161,0 & 65,7 & 69,0 & 51,0 & 92,9 \\
100.000 a 500.000 hab. & 26,1 & 79,8 & $-16,8$ & 5,1 & $-18,5$ & 6,1 \\
500.000 a 1.000.000 hab. & n.d. & 38,4 & $-97,2$ & n.d. & $-74,2$ & $-48,60$ \\
Mais de 1.000.000 hab. & $-46,7$ & 27,5 & $-229,2$ & $-238,1$ & $-286,8$ & $-172,0$ \\
Total & 23,6 & 97,1 & $-61,9$ & $-1,4$ & $-42,4$ & 0,0 \\
\hline
\end{tabular}

Fonte: Maia Gomes, McDowell (1997); a partir de dados brutos extraídos de: Sintese/Dataprev e IBGE - Contagem da População 1996.

Gráfico 3 - Brasil e Nordeste: Participação do valor dos benefícios rurais e assistenciais no PIB por Estados - 1995-97

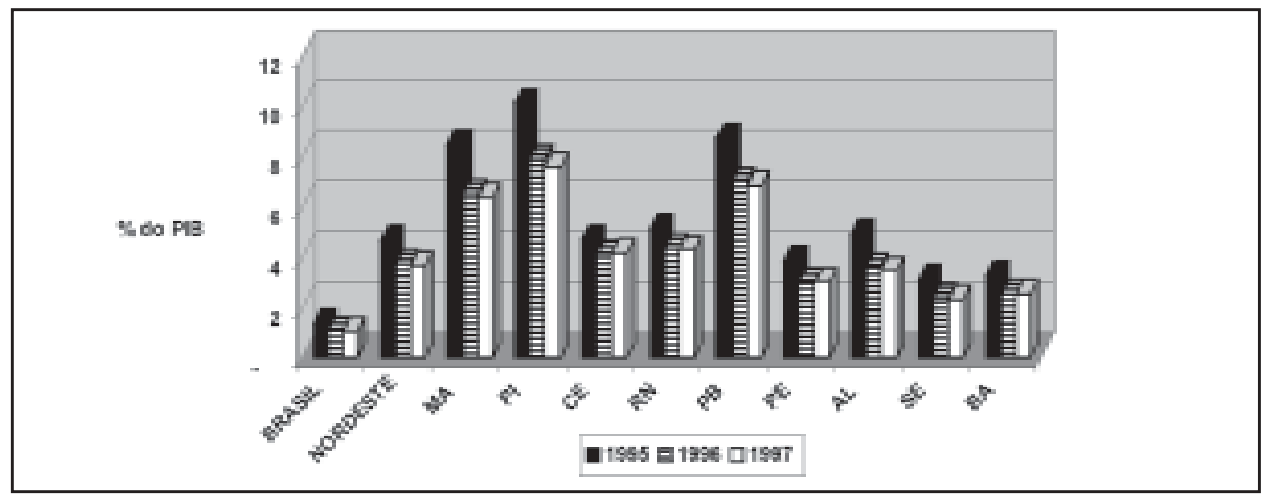

Fonte: MPAS/SPS, IPEA

Já o Gráfico 3 apresenta o significativo impacto interestadual redistributivo de renda para o caso das aposentadorias rurais e dos benefícios assistenciais (RMV e amparo-LOAS) nos Estados do Nordeste, medido pela proporção dos benefícios sobre o PIB regional. A Paraíba e o Piauí - dois Estados com indicadores sociais menos favoráveis - bem como o Maranhão, o Estado com a menor taxa de urbanização do Nordeste, figuram entre os principais beneficiados. Há, sem dúvida, um destaque absoluto da Região Nordeste em termos de repercussões redistributivas de renda do subsistema previdenciário rural. Os Estados de outras regiões do país, entre as quais a Região Norte, não apresentam na média índices de impacto comparáveis aos do Nordeste. Embora a maioria dos estudos sobre a diversidade regional do Brasil utilize os Estados como unidade básica, sabe- 
se que é possível encontrar, quando de uma análise intermunicipal, dentro de muitos dos Estados, um universo por vezes no mínimo tão heterogêneo quanto o interestadual brasileiro.

\section{Impactos redistributivos no Estado do Pará}

A introgeneidade intra-estado parece ser particularmente verdadeiro no caso do Pará, onde se verifica uma história de ocupação territorial e desenvolvimento socioeconômico marcada pela convivência e sobreposição de estruturas regionais geradas desde a fase colonial e imperial (com manifestações urbanas principalmente em Belém, Cametá e Bragança), com regiões que se desenvolveram durante o ciclo da borracha, outras que receberam imigração nordestina, européia e japonesa, calcadas na pequena propriedade rural, outras mais que foram ocupadas recentemente com o avanço da "fronteira agrícola" do Mato Grosso em direção ao norte, as ondas de migração do Nordeste para o Norte (tendo o Maranhão e, depois, o Pará como "porta de entrada"). O Pará, pela sua conformação histórica, apresenta em seu território um alto grau de heterogeneidade socioeconômica intermunicipal, o que também pode estar refletido em um peso diferenciado dos benefícios da previdência rural para alguns municípios em comparação a outros.

Uma forma ainda pouco difundida de abordar o sistema da previdência rural seria vê-lo como um segundo sistema, parafiscal, de redistribuição inter-regional de renda, paralelo aos canais fiscais tradicionais do ponto de vista dos municípios, entre os quais se destaca o Fundo de Participação de Municípios (FPM) e a Cota-Parte do ICMS. Tanto o FPM, quanto a Cota-Parte dividem entre os municípios parte da receita tributária da União ou dos Estados, respectivamente. Apresentou-se a oportunidade de fazer, para o Estado do Pará, uma comparação entre as transferências pelos canais fiscais (FPM e Cota-Parte do ICMS) e as transferências pelo sistema de aposentadorias rurais, identificando-se eventuais grupos de municípios que se diferenciassem uns dos outros quanto à importância das transferências obtidas por uma ou outra fonte de transferências. Em uma primeira aproximação para o Estado do Pará como um todo, para se dar conta da importância quantitativa das transferências via benefícios rurais basta ressaltar que estas (R\$ 305 milhões) equivaliam em 1995 a aproximadamente 4/5 das transferências brutas via ICMS e FPM (R\$ 388 milhões). Igualmente, as transferências via benefícios rurais, praticamente igualavam a totalidade da arrecadação federal de impostos no território do Pará (R\$ 316 milhões) naquele mesmo ano.

Análises mais detalhadas são feitas a seguir, abrangendo 104 de 143 municípios do Pará: aqueles para os quais foi possível obter os dados tributários e previdenciários consolidados para o ano de 1995. Os resultados estão apresentados na Tabela 7, na qual, trabalha-se com transferências brutas, sem descontar dos valores transferidos a arrecadação de impostos estaduais ou federais. 
Na mencionada Tabela 7, divide-se o Estado do Pará em dois grupos. um primeiro chamado de "Municípios Fiscais": aqueles em que as transferências pelos canais fiscais do FPM e da Cota-Parte do ICMS têm mais peso relativo. Um segundo grupo foi denominado de "Municípios Previdenciários": aqueles municípios, em que as transferências recebidas pelas famílias do município a partir do sistema de previdência rural suplantam as transferências recebidas pelo município pelos mecanismos fiscais acima.

É necessário apontar o fato de que a natureza das transferências em discussão é bastante diferente - as transferências fiscais direcionam-se ao tesouro municipal e percorrem a via do orçamento público, enquanto as transferências previdenciárias chegam diretamente aos segurados e suas respectivas unidades domiciliares/famílias.

A proporção entre as transferências previdenciárias rurais e as fiscais está representada na linha G da Tabela. Em média, os municípios paraenses estudados receberam em 199572 centavos de transferências previdenciárias rurais para cada real de transferências fiscais. A mesma proporção também seria obtida se fosse feita a divisão do valor da linha H (gasto médio em benefícios da previdência rural por habitante-ano) pelo da linha I (transferência média recebida do FPM/ICMS por habitante-ano).

Os municípios "fiscais", correspondem a 3/5 do total de municípios estudados, cobrem 2/3 da população e recebem 3/4 das transferências fiscais. Já o grupo dos municípios "previdenciários" responde por $2 / 5$ dos municípios analisados, os quais correspondem a $1 / 3$ da população, mas a 54,4\% do volume de gastos da Previdência Rural nos municípios mencionados em 1995.

Os Gráficos 4 e 5 apresentam ensaios de agrupamento dos municípios estudados. Sobressai que os municípios previdenciário rurais são aqueles que parecem apresentar um dos dois seguintes perfis: ou são os pólos locais de pequenas regiões ribeirinhas ou ilhas características da Amazônia, onde se concentram serviços urbanos, ou se trata daqueles municípios de regiões interiores, porém de colonização antiga, as "fronteiras velhas" (como a microrregião bragantina da mesorregião do Nordeste Paraense), onde já houve um amadurecimento demográfico da população ocupada na agricultura. 


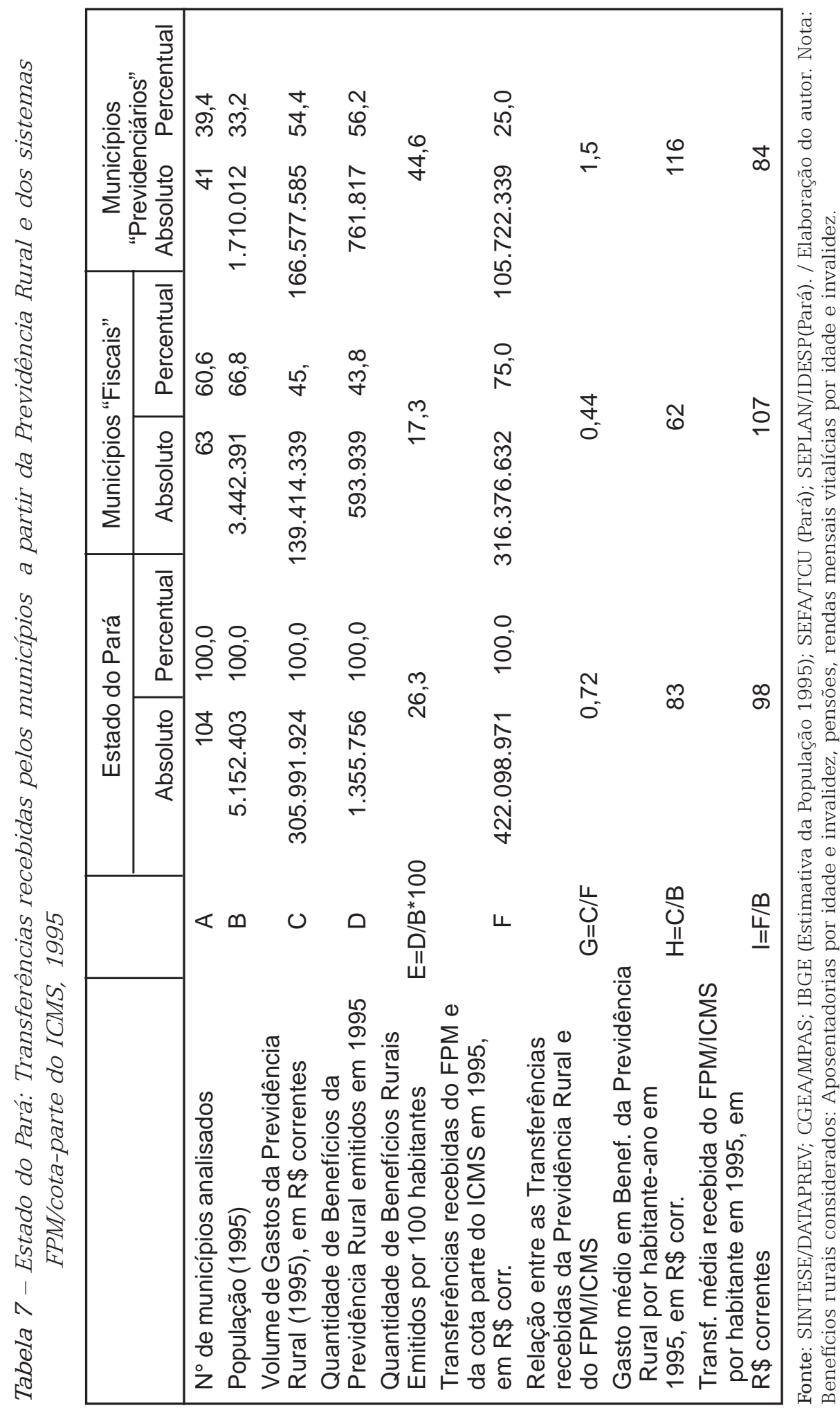


Gráfico 4 - Pará: Um possível agrupamento dos municípios "fiscais"

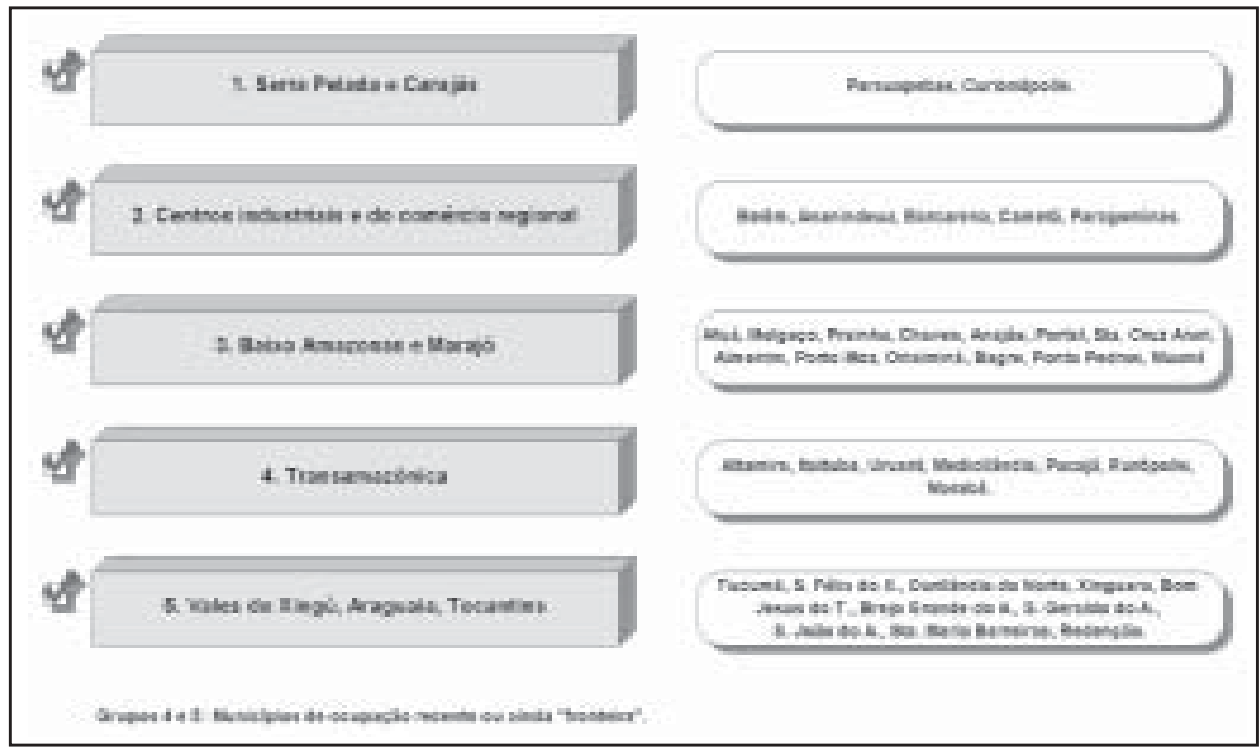

Gráfico 5 - Pará: Um possível agrupamento dos municípios "previdenciários"

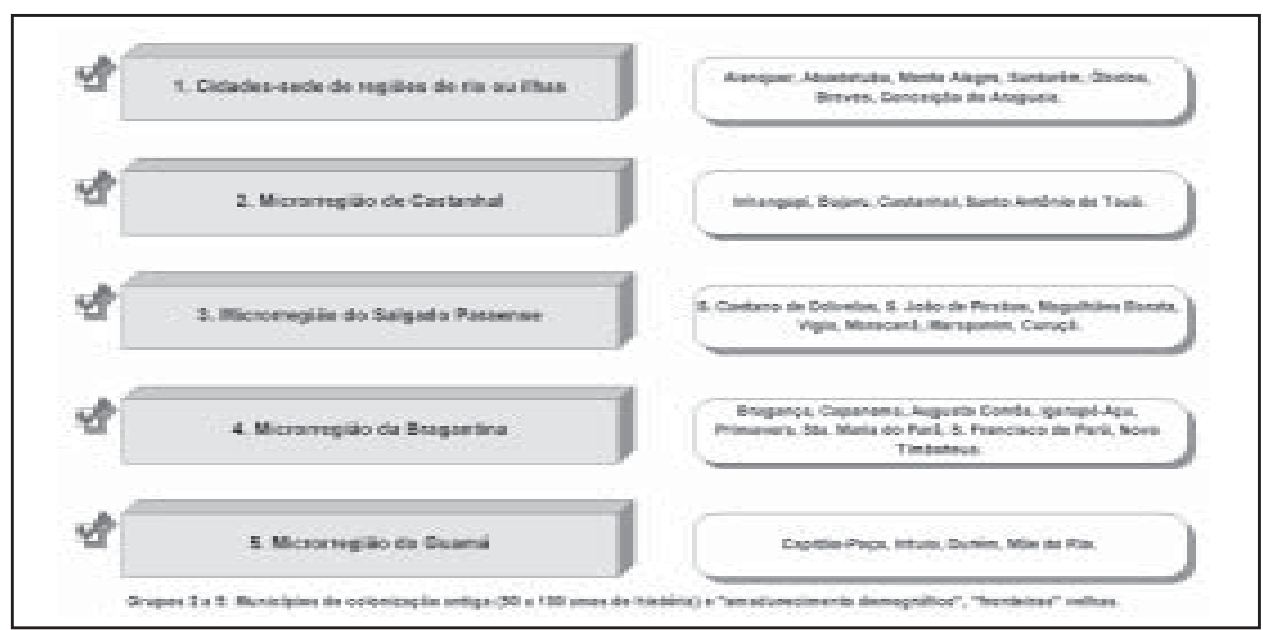

\section{Perspectivas das aposentadorias rurais no Pará}

Um primeiro cenário resulta da hipótese de que os ciclos de migração recentes terão elevada influência sobre o perfil futuro de distribuição de beneficiários rurais, uma vez que em muitas mesorregiões a ocupação no campo ainda não chegou a um amadurecimento demográfico. Dessa forma, o impacto redistributivo interregional dos benefícios rurais ainda pode aumentar ao longo das próximas décadas, à medida que, por exemplo, a população ocupada na agricultura em regiões como o percurso da Transamazônica e o Sul Paraense "envelheça". 
Os Gráficos 6 a 8 mostram que houve uma significativa expansão recente da ocupação na agricultura, do número de estabelecimentos rurais e da área de lavouras em duas mesorregiões onde desenvolvem-se recentemente fronteiras agrícolas, o Sudeste e Sudoeste Paraense, de modo que seria razoável esperar, dentro de possivelmente uma a duas décadas, um volume significativo de benefícios rurais. Ao mesmo tempo, parece claro que no Nordeste Paraense, onde as aposentadorias rurais hoje já possuem um papel relevante (vide Tabela 4 e Gráfico 5), em geral não mais deve ser palco de significativo crescimento do número de beneficiários no futuro ${ }^{9}$. Cumpre salientar, entretanto, o interessante fato de que há, mesmo dentro da Mesorregião Nordeste Paraense, algumas áreas de ocupação mais recentes, em especial na Microrregião do Guamá. Essas regiões recentes poderiam constituir exceções a uma possível tendência de estagnação da concessão de benefícios rurais no Nordeste Paraense.

Gráfico 6 - Pará: Número de estabelecimentos rurais por mesorregiões, 1970-1995/96

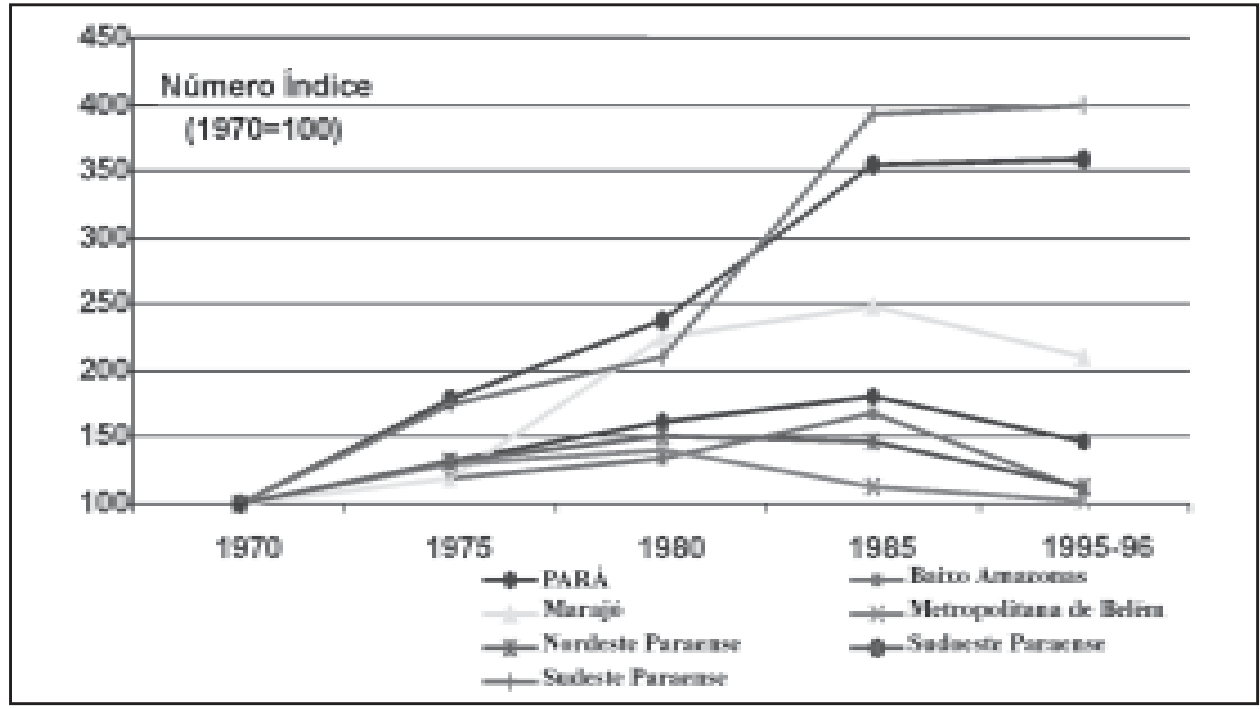

Fonte: IBGE (Centros Agropecuários)

\footnotetext{
Os dados constantes dos Gráficos 6 a 8 foram levantados por municípios a partir dos Censos Agropecuários de 1970 a $1995 /$ 96. Como de 1970 em diante houve significativas modificações na malha municipal do Estado do Pará, a reconstituição da série histórica por municípios, micro e mesorregiões efetuou-se somando valores para municípios constantes dos Censos de 1975 em diante de sorte a retornar-se à malha municipal de 1970. Houve que se criar regras arbitrárias de divisão e soma de valores quando de municípios, cuja área foi desmembrada de mais de um município originário. Por isso, é possível que o leitor tenha a impressão de uma imprecisão dos valores citados - no entanto, a divisão de municípios entre micro e mesorregiões no Pará aqui utilizada corresponde à de 1970 e não à de 1999. A relação dos passos de soma e divisão consta do Anexo deste trabalho.
} 
Gráfico 7 - Pará: Pessoal ocupado na agricultura por mesorregiões, 19701995/96

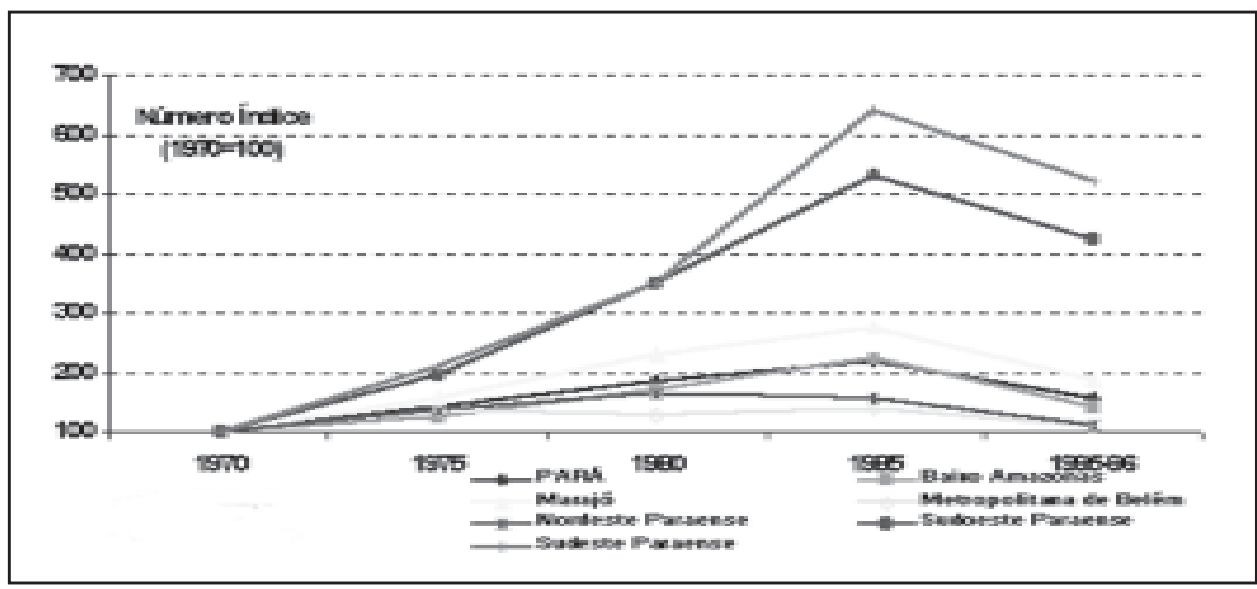

Fonte: IBGE (Censos Agropecuários)

Gráfico 8 - Pará: Área de lavoura por mesorregiões, 1970-1995/96

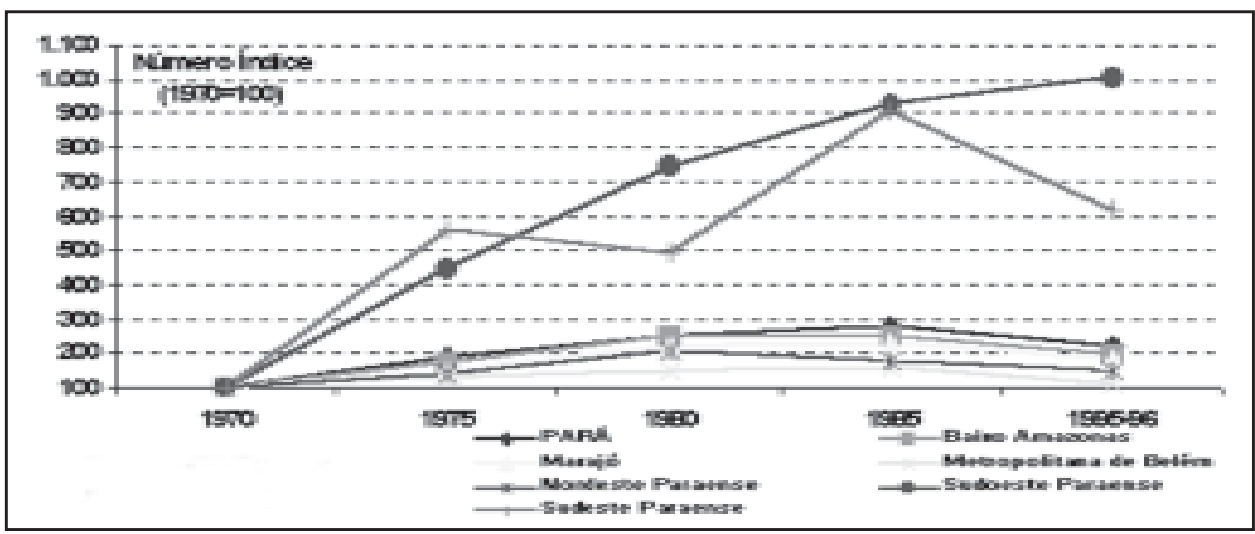

Fonte: IBGE (Censos Agropecuários)

\section{Impactos socioeconômicos das aposentadorias rurais em Iga- rapé-Açu, Bragantina: um estudo de caso no Pará}

Entre os meses de março e maio de 1998, realizamos 36 entrevistas com beneficiários rurais e beneficiários do amparo assistencial (Benefício de Prestação Continuada - BPC - da Lei Orgânica de Assistência Social) no município de Igarapé-Açu (PA). O objetivo das entrevistas foi detectar o impacto socioeconômico desses benefícios sobre as unidades familiares, isto é, os domicílios dos beneficiários. Optou-se por fazer entrevistas, pois os dados socioeconômicos disponíveis a partir de fontes secundárias não permitem um nível de desagregação que diferencie beneficiários urbanos de rurais. É que a Pesquisa Nacional por Amostra de Domicílios - PNAD - do IBGE, que trabalha com essa desagregação, não é feita para a região rural da Amazônia. 
O município de Igarapé-Açu escolhido para a pesquisa é representativo da Microrregião Bragantina, no Nordeste do Estado do Pará. Ademais, lá desenvolvem-se diversos estudos socioeconômicos por uma parceria entre o Núcleo de Altos Estudos Amazônicos, NAEA, da UFPA, e a Universidade Livre de Berlim.

A Microrregião Bragantina está localizada na Região Nordeste do Estado do Pará, próximo à costa atlântica, entre os municípios de Castanhal a oeste e o limite do Pará com o Estado do Maranhão a leste. Ao norte, ficam os municípios costeiros do Pará, que, na sua maioria, fazem parte da Microrregião do Salgado. Ao sul, a delimitação é com a Microrregião da Guajarina (Guamá).

A Bragantina é formada atualmente por 13 municípios $^{10}$, entre os quais os de maior número de habitantes são Bragança e Capanema. Possuía em 1996, conforme a Contagem da População do IBGE, 301.558 habitantes. A densidade populacional local é maior que a média do Estado do Pará (vide tabela e figura no anexo). Sua economia é basicamente agrícola, apesar da existência de algumas empresas do setor industrial - em especial agroindustrial - nas suas maiores cidades.

A ocupação da Microrregião Bragantina deu-se inicialmente por migrantes de curta distância, em especial deslocamentos de habitantes da região litorânea, que usavam para tal os igarapés que cortam a Bragantina. A colonização mais recente da região inicia ao final do século XIX e princípio do século XX, tendo como impulso fundamental a construção da ferrovia Bragança-Belém (1883-1908). Além de colonos de origem espanhola, foram em especial as ondas de migração do Nordeste para a Amazônia, principalmente conforme as grandes secas naquela macrorregião, que marcaram o perfil do contingente que migrou para a Bragantina. Mais recentemente, um novo grupo populacional - os descendentes de imigrantes japoneses - veio para Igarapé-Açu, deslocando-se desde ToméAçu devido a uma crise na agricultura daquele município. Outro ponto de inflexão na história regional recente, igualmente marcado pela modificação estrutural da modalidade de transporte disponível na região, é dado pelo ano de 1965, ano em que, ao mesmo tempo, foi desativada a ferrovia e concluída a construção da rodovia Belém-Brasília. A abertura das Rodovias Belém-Maranhão e Belém-Brasília na década de 60 (esta última asfaltada em 1973) aprofundou um processo de despolarização da economia paraense oriental em relação a Belém. A Bragantina, que já possuía uma significativa conexão comercial com os atacadistas do Sul-Sudeste e Nordeste do País, via Castanhal, passa a estar definitivamente vinculada ao mercado nacional sem a necessidade de intermediação de Belém.

${ }^{10}$ Os municípios são: Augusto Corrêa, Bonito, Bragança, Capanema, Igarapé-Açu, Nova Timboteua, Peixe-Boi, Primavera, Santa Maria do Pará, Santarém Novo, São Francisco do Pará, Quatipuru e Tracuateua. 


\section{O Município de Igarapé-Açu - aspectos econômicos}

O município de Igarapé-Açu foi fundado em 1906 em função da ferrovia Bragança-Belém ${ }^{12}$. Ele possui, como municípios vizinhos, ao norte Marapanim e Maracanã (da Microrregião do Salgado), a leste Santa Maria do Pará e Nova Timboteua (Bragantina), a oeste São Francisco do Pará (Bragantina) e ao sul Castanhal (Microrregião de Castanhal). Possui uma área de 756 quilômetros quadrados e está situado a $1^{\circ} 07^{\prime} 41^{\prime \prime}$ latitude sul e 47 47'15" longitude oeste. Pelo seu território passam quatro rios principais (JambuAçu, Igarapé-Açu, Caripi e Maracanã), que fluem no sentido sul-norte em direção ao Oceano Atlântico. No município, por ocasião de sua colonização no século XX, foram abertas travessas paralelas e perpendiculares, formando quadrados de 2 quilômetros de lado. Essa estrutura existe em grande parte ainda hoje. Os lotes-padrão oferecidos aos colonos tinham 400 metros de frente por $1 \mathrm{~km}$ de profundidade. Razão por que, hoje, apesar de algum processo de concentração fundiária, há uma presença significativa da micro e da pequena propriedade: 94\% dos agricultores do município dispõem de propriedades de até 100 hectares de extensão (Arapiraca da Silva et. al., 1999). Em comparação com outras regiões do Pará, o município tem uma situação fundiária relativamente estável e tranqüila.

Na distinção realizada acima Igarapé-Açu, que apresenta uma incipiente arrecadação própria de tributos municipais, ficou classificado como sendo do segundo grupo, como município "previdenciário", dada a clara preponderância da Previdência Rural sobre as transferências brutas recebidas pelo município a partir do FPM e da Cota-Parte do ICMS (1,75:1,00), bem como sobre as transferências líquidas $(2,51: 1,00)$ (vide anexo).

Na economia agrícola local, o produto mais freqüentemente cultivado é a mandioca, cuja produção é vendida sob a forma de farinha a intermediários de Belém. Estes passam aproximadamente de forma quinzenal, comprando a produção para a venda. Vale registrar uma controvérsia sobre a característica da pequena produção - aquela basicamente realizada com mão-de-obra familiar - na Bragantina e em outras regiões do Nordeste Paraense, onde na literatura conflita a idéia de uma produção basicamente de subsistência com a interpretação de que se trata de produtores fortemente integrados ao mercado, apesar de uma parcela não desprezível de autoconsumo (Sawyer, 1979; Costa, 1989; Santana, 1990; Hurtienne, 1999). Além do algodão, a pimenta-do-reino e o maracujá constituem dois outros produtos de agricultores mais capitalizados, pois exigem investimento em infra-estrutura (estaqueamento) e financiamento da compra de mudas.

No Gráfico 9, estão representados respectivamente para a Bragantina e Igarapé-Açu a evolução do número de estabelecimentos rurais, o pessoal ocupado na agricultura e a área de lavoura em culturas perenes e temporárias. 
Há um claro descolamento na evolução das três curvas. Em primeiro lugar, chama a atenção o salto na área de lavouras na primeira metade dos anos 70, que não foi acompanhado de evolução proporcional do pessoal ocupado e do número de estabelecimentos. Posteriormente, a área de lavoura começa a decair continuamente. A explicação para essa evolução poderia ser o fato de, entre 1975 e 1990, ter havido um crescimento pronunciado da área de lavouras perenes (principalmente pimenta). Embora esse crescimento estivesse tendencialmente acompanhado de um leve declínio da área de lavouras temporárias, é preciso salientar também que houve uma expansão bastante forte da produção de mandioca, dada uma evolução bastante favorável do seu preço naquele período. O valor da produção das lavouras de Igarapé-Açu, de acordo com dados da Produção Agrícola Municipal, teria crescido entre 1979 e 1989 em aproximadamente $400 \%$. Mais recentemente, no entanto, na década de 90, o preço da mandioca apresentou queda profunda $(1991=100,1997=19)$, ao passo que a pimenta e o maracujá apresentam preços mais favoráveis que em 1991 (respectivamente $1997=303$ e 227).

Gráfico 9 - Igarapé-Açu: Número de estabelecimentos rurais, pessoal ocupado na agricultura e área de lavoura, 1970-1995/96

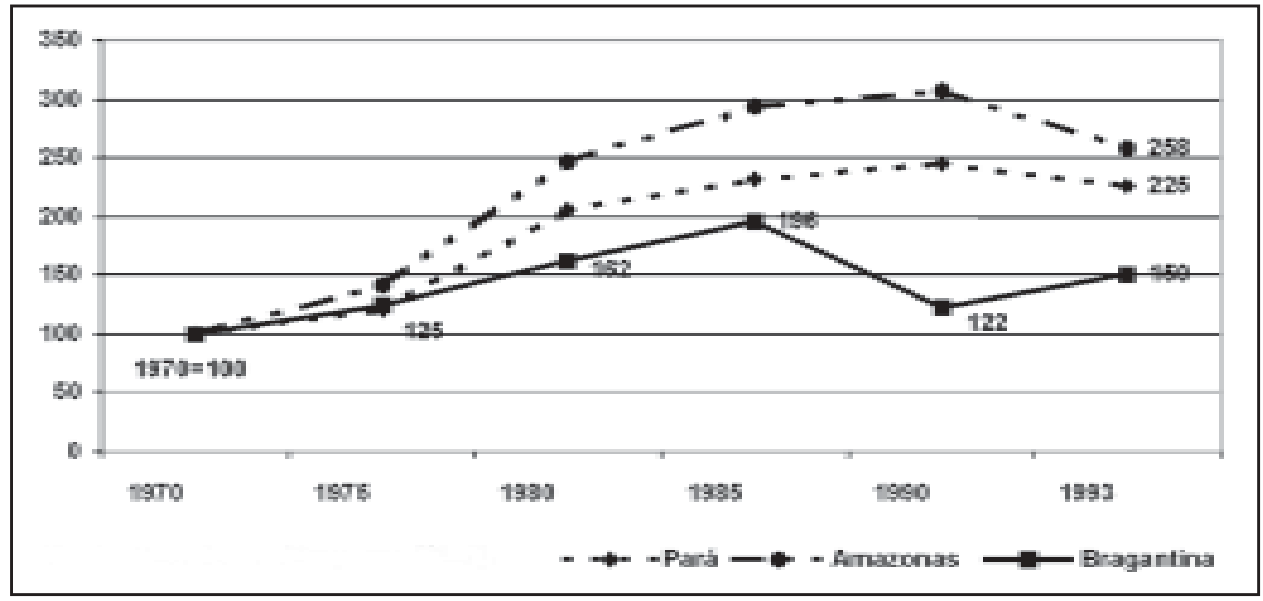

Fonte: Maia Gonçalves/Vergolino (1997)

No Gráfico 9 verifica-se, também, a queda acentuada do número de estabelecimentos agrícolas em Igarapé-Açu, o que sugere a possibilidade de um processo de concentração fundiária, já que a área plantada permanece razoavelmente elevada. A terceira característica da evolução agrícola de Igarapé-Açu é que, em pleno movimento de queda da área plantada e do número de estabelecimentos, atinge-se o ápice do número de pessoas ocupadas na agricultura em 1985. 
O Município de Igarapé-Açu - aspectos sociais, demográficos e de mercado de trabalho

Pelo Índice de Desenvolvimento Humano Municipal (IDH-M) ${ }^{11}$, a Bragantina e Igarapé-Açu estão entre as regiões comparativamente mais pobres do Brasil e, mesmo, do Estado do Pará (vide Gráfico 10). Em comparação com todos os municípios do Brasil, o município de Igarapé-Açu localiza-se aproximadamente no topo do terço inferior em termos de IDHMunicipal (vide Gráfico 11).

Gráfico 10 - Igarapé-Açu: Índice de Desenvolvimento Humano Municipal, 1991

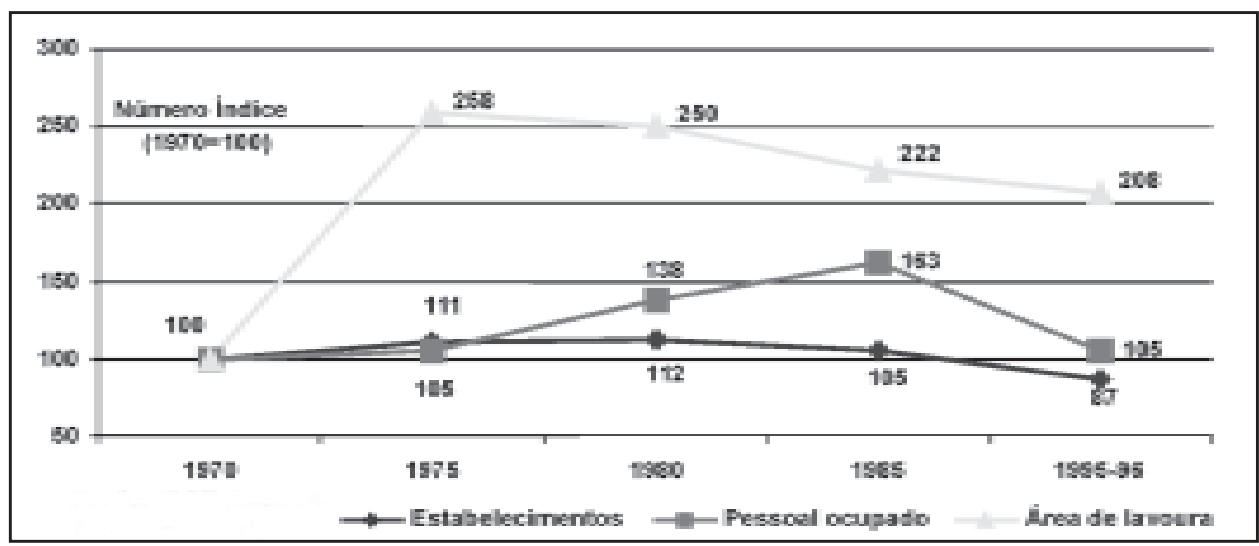

Fonte: IBGE (Censos Agropecuários)

Gráfico 11 - Igarapé-Açu: Índice de Desenvolvimento Humano Municipal, 1991

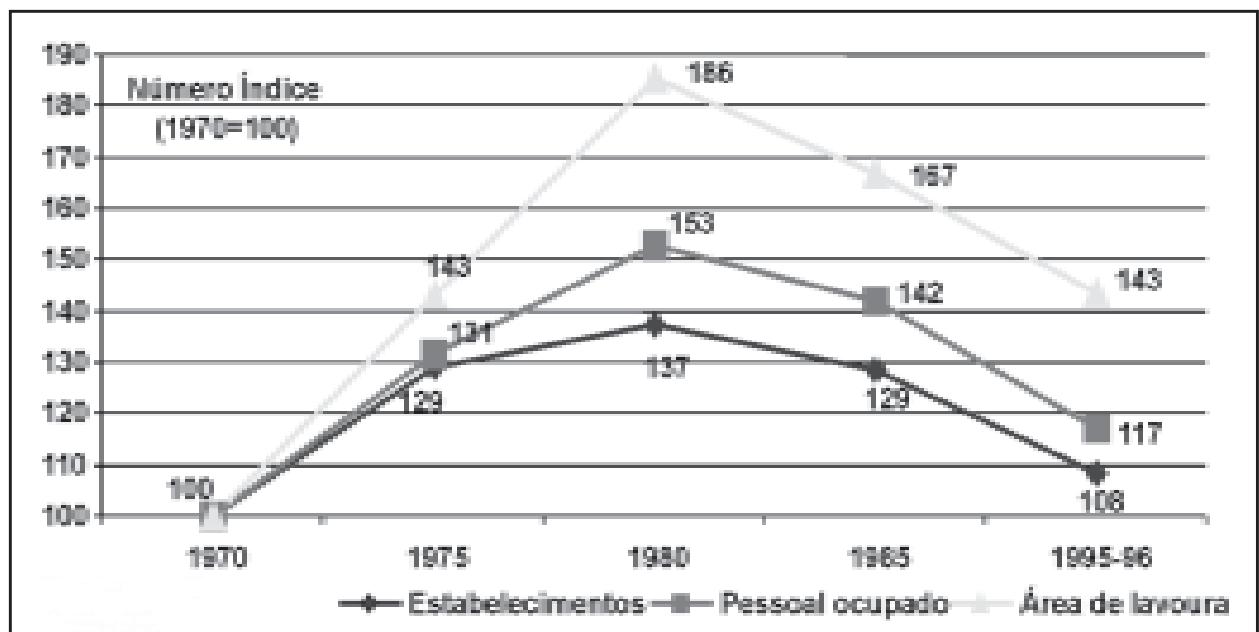

Fonte: IBGE (Censos Agropecuários)

${ }_{11}$ Trata-se de um indicador social composto, desenvolvido por IBGE, IPEA e Fundação João Pinheiro a partir da metodologia adaptada do Índice de Desenvolvimento Humano (IDH) do Programa das Nações Unidas para o Desenvolvimento (PNUD). Ele varia de 0 (mínimo) a 1 (máximo). 
Helmut Schwarzer

Tabela 8 - Brasil, Região Norte, Pará, Bragantina e Igarapé-Açu: Indicadores sociais selecionados, componentes do IDH-M, 1991

\begin{tabular}{|c|c|c|c|c|c|}
\hline & Brasil & Região Norte & Pará & Bragantina & Igarapé-Açu \\
\hline \multicolumn{6}{|l|}{ a) Longevidade: } \\
\hline 1) Expectativa de vida ao nascer & 63,3 & 61,8 & 61,1 & 57,6 & 57,8 \\
\hline 2) Taxa de mortalidade infantil & 49,5 & 51,0 & 52,6 & 70,9 & 69,8 \\
\hline \multicolumn{6}{|l|}{ b) Educação: } \\
\hline \multicolumn{6}{|l|}{ 3) População 25+ anos (\%) com } \\
\hline - menos de 4 anos de estudo & 42,3 & 53,3 & 54,0 & 67,8 & 67,3 \\
\hline - menos de 8 anos de estudo & 72,1 & 77,8 & 78,2 & 88,9 & 87,8 \\
\hline - acima de 11 anos de estudo & 7,5 & 3,6 & 3,7 & 0,9 & 0,7 \\
\hline 4) Taxa de analfabetismo (população de 15+) & 19,4 & 24,1 & 23,6 & 32,2 & 31,2 \\
\hline $\begin{array}{l}\text { 5) Número médio de anos de estudo } \\
\text { (da população de } 25+\text { ) }\end{array}$ & 4,9 & 4,0 & 4,0 & 2,8 & 2,8 \\
\hline \multicolumn{6}{|l|}{ c) Infância: } \\
\hline 6) Crianças (7-14) fora da escola (em \%) & 22,7 & 30,8 & 30,0 & 31,8 & 26,3 \\
\hline 7) Crianças (10-14) trabalhadoras (em \%) & 8,6 & 6,7 & 6,6 & 9,0 & 6,9 \\
\hline \multicolumn{6}{|l|}{ d) Renda: } \\
\hline \multicolumn{6}{|l|}{ 8) Renda familiar per capita média } \\
\hline 9) Grau de desigualdade (Theil-L) & 0,78 & 0,72 & 0,70 & 0,55 & 0,54 \\
\hline 10) Pessoas c/renda insuficiente (P0) (em \%) & 45,5 & 58,6 & 61,9 & 76,3 & 74,8 \\
\hline 11) Insuficiência média de renda (P1) & 0,24 & 0,31 & 0,33 & 0,43 & 0,42 \\
\hline $\begin{array}{l}\text { 12) Grau de desig na população } \\
\text { c/renda insuficiente (P2) }\end{array}$ & 0,16 & 0,21 & 0,21 & 0,29 & 0,27 \\
\hline \multicolumn{6}{|l|}{ e) Habitação: } \\
\hline $\begin{array}{l}\text { 13) Pop c/domicílio de material de } \\
\text { construção durável (em \%) }\end{array}$ & 91,6 & 76,7 & 73,2 & 45,4 & 44,3 \\
\hline 14) Pop c/domicílio c/abastecim de água & & & & & \\
\hline $\begin{array}{l}\text { água adequado (em \%) } \\
\text { 15) Pop c/domicílio c/instalação adequada }\end{array}$ & 83,9 & 59,2 & 56,4 & 45,8 & 59,5 \\
\hline de esgoto (em \%) & 58,9 & 32,6 & 37,3 & 31,6 & 34,0 \\
\hline
\end{tabular}

Fonte: PNUD/IPEA/IBGE/FJP (1998a). Notas: Theil-L: Indicador de desigualdade da distribuição de renda, cujo valor é zero para distribuição igualitária e crescente para maior desigualdade. Exclui do seu cálculo, por questões técnicas, aqueles indivíduos com renda igual a zero. P0, P1, P2: Indicadores de pobreza construídos conforme a metodologia de Foster, Greer G Thorbecke (1984). PO: Proporção de pessoas com renda familiar per capita inferior a 0,50 salários mínimos (de set. 1991). P1: Indicador de distância da renda dos indivíduos com renda insuficiente em relação a 0,50 salários mínimos "média dos hiatos relativos de renda, medidos como fração da linha de insuficiência". P2: Indicador de variações na incidência de indivíduos com renda insuficiente, bem como da defasagem e distribuição de renda entre esses indivíduos "média dos quadrados dos hiatos de renda". 
Na Tabela 8 estão alguns dos indicadores componentes do IDH-M, que caracterizam a situação social de Igarapé-Açu e da Bragantina. Em praticamente todos os indicadores, o município de Igarapé-Açu está ligeiramente acima da média dos municípios da Microrregião da Bragantina, mas ambos estão em situação social precária, quando comparados às médias do Estado do Pará, da Região Norte e do Brasil. Como exceção dessa tendência, constatam-se no município de Igarapé-Açu indicadores relativamente favoráveis no grupo Infância (Grupo C, indicadores 6 e 7) e na proporção de domicílios com abastecimento de água considerado adequado pelos critérios do IBGE (indicador 14).

Um dos grupos de indicadores, que deixa essa precariedade mais visível, é o relativo à Renda ${ }^{12}$ (Grupo D, Tabela 9). Tanto a Bragantina, quanto Igarapé-Açu estavam em 1991 mais da metade abaixo da média brasileira no tocante à renda familiar per capita média, perto mesmo da linha de pobreza (0,50 salário mínimo) utilizada como linha de corte no estudo do IDHM. O grau de desigualdade, medido pelo índice Theil-L, é mais baixo que as médias do Estado do Pará, da Região Norte e do Brasil, pois a homogeneidade maior na distribuição de renda deve-se ao fato de a extensão de pobreza, definida em termos de disponibilidade de renda monetária, ser muito mais ampla: a aparente "vantagem" da região, quando comparada ao restante do país, pode ser ilusória. O conjunto de indicadores P0, P1 e P2, conforme a metodologia de Foster et. al., demonstra esse fato. Por meio do indicador P0 verifica-se um elevado percentual de pessoas (quase 3/4 da população no caso de Igarapé-Açu), abaixo da linha de pobreza adotada no estudo. O indicador P1 mostra, para Igarapé-Açu e a Bragantina, uma distância média maior das pessoas consideradas pobres em relação à linha de pobreza do que no restante do Brasil. Por fim, o indicador P2 relata que o grau de heterogeneidade entre aqueles que estão abaixo da linha de pobreza, no município de Igarapé-Açu e na Bragantina, é maior do que as médias para outros lugares, ou seja: na região há pobreza com graus mais elevados de intensidade.

${ }^{12}$ Um argumento contra o uso de indicadores baseados unicamente na renda, ainda mais no caso da agricultura familiar, é o fato de indicadores de renda captarem tão somente a dimensão monetária e não o eventualmente elevado autoconsumo. 


\section{Demografia e emprego}

Para uma caracterização pormenorizada da estrutura demográfica da Bragantina e do município de Igarapé-Açu, utilizam-se aqui os dados do Censo Demográfico do IBGE de 1991, para o qual os microdados estavam disponíveis. Nesse ano residiam em Igarapé-Açu 27.307 pessoas, divididas entre 13.963 homens (51\%) e 13.344 mulheres (49\%). Em 1991 encontravam-se nas faixas etárias aptas a solicitar aposentadoria rural por idade (a partir de 1992: 60+/55+ para H/M) 1.045 homens e 1.221 mulheres. Conforme a Contagem Populacional de 1996, nesse ano Igarapé-Açu registrava 30.651 habitantes, repartidos em 15.681 homens e 14.970 mulheres.

Na Tabela 9 estão dispostos alguns indicadores da estrutura demográfica do município de Igarapé-Açu e da Bragantina, comparados às médias do Estado do Pará, do Brasil e das áreas urbanas da Região Sul do país. É possível verificar que tanto Igarapé-Açu, quanto a Bragantina estão em estágios relativamente iniciais do processo que os demógrafos chamam de "transição demográfica", ao longo do qual a população em estudo modifica seus perfis epidemiológicos e a distribuição da população por faixas etárias.

Tabela 9 - Igarapé-Açu, Bragantina, Pará, Brasil e Sul Urbano: Indicadores da estrutura populacional, 1991

\begin{tabular}{|lc|c|c|r|r|}
\hline & Igarapé-Açu & Bragantina & Pará & Brasil & Sul Urbano \\
\hline Porcentagem de população em cada faixa etária: & & & & \\
- 0-14 (Jovens) & 44,5 & 45,0 & 42,5 & 34,7 & 31,5 \\
-15-64 (População ativa) & 50,7 & 50,6 & 54,3 & 60,5 & 63,6 \\
-65+(Idosos) & 4,8 & 4,4 & 3,2 & 4,8 & 4,9 \\
Taxas de dependência demográficas: & & & & & \\
Jovens/População ativa & 0,88 & 0,89 & 0,78 & 0,57 & 0,49 \\
Idosos/População ativa & 0,09 & 0,09 & 0,06 & 0,08 & 0,08 \\
Jovens+ldosos/Popul. ativa & 0,97 & 0,98 & 0,84 & 0,65 & 0,57 \\
\hline
\end{tabular}

Fonte: IBGE (Censo Demográfico 1991).

Em Igarapé-Açu e na Bragantina, em geral a participação da população jovem (definida conforme critérios internacionais como sendo a população de até 14 anos de idade completos) é alta, quando comparada com as médias das demais regiões e do Brasil, mostradas na tabela. Curioso é o fato de a participação da população idosa ser maior nesta fase da transição demográfica do que a média do Estado do Pará, o qual possui uma estrutura populacional intermediária entre a Bragantina e a média brasileira. Isso deve-se ao fato de que, com a queda da fecundidade (número médio de filhos por mulher em idade fértil), que acompanha a transição demográfica, a parcela da população que cresce mais significativamente é a população em idade ativa, diminuindo a participação percentual dos idosos na pirâmide populacional. Esta somente volta a crescer em um mo- 
mento posterior da transição, quando a população em estudo "amadurece", como demonstrado pela estrutura do Sul Urbano. Esse processo também pode ser acompanhado pelas taxas de dependência demográfica, que indicam a proporção representada pelas faixas de idade inativas em relação à população em idade ativa (PIA). Aqui se verifica que a queda na participação dos jovens, com o passar do tempo, mais do que compensa o aumento da população idosa e, na somatória, há uma redução da taxa de dependência total (jovens mais idosos em relação à PIA), o que permitiria, caso outras condições fossem satisfeitas, um salto de qualidade nas políticas sociais de populações nesta fase de transição demográfica (abre-se uma "janela de oportunidade demográfica").

As pirâmides demográficas de 1991 das diversas populações mencionadas na Tabela 9 demonstram o que foi afirmado (vide Gráfico 12). Nota-se que as pirâmides da Bragantina e de Igarapé-Açu possuem uma base muito larga, denotando o grande contingente de jovens na sua estrutura populacional, o que certamente está relacionado com a lógica da pequena produção familiar, conforme relatado acima, em que a mão-de-obra dos filhos é insumo relevante na estratégia das pequenas unidades produtivas. Já as pirâmides relativas ao Estado do Pará e à média brasileira denotam etapas posteriores do processo de transição demográfica, o qual, no Brasil, encontra-se em estágio mais avançado no Sul Urbano, cuja pirâmide gradativamente toma o formato de um cilindro. Essa estrutura, que o Sul Urbano apresentava em 1991, vai ser atingida aproximadamente pelo Estado do Pará cerca de 30 anos depois, em 2020, conforme projeção da Diretoria de Política Social do IPEA (incorporando os dados e as tendências recentemente reveladas na Contagem Populacional de 1996).

O mercado de trabalho formal de Igarapé-Açu, conforme os dados da Relação Anual de Informações Sociais (RAIS) do Ministério do Trabalho, é bastante restrito, com apenas 376 vínculos empregatícios declarados no mês de dezembro de 1995 (Tabela 11). Ao longo de todo o ano de 1995, foram registrados 574 vínculos empregatícios formais, do que é possível inferir uma taxa de rotatividade alta, ou seja, um tempo médio de permanência no emprego provavelmente baixo. O maior empregador é a Administração Pública (Prefeitura Municipal), destacando-se o sistema educacional. A Prefeitura Municipal também parece ser um empregador com grande constância dos seus vínculos empregatícios, a julgar pelo fato de que ao longo de 1995 apresentou o mesmo total de 206 empregados de dezembro. Uma flutuação de emprego extremamente acentuada ocorreu no setor "Outros/Ignorado", que registrou 232 vínculos empregatícios ao longo do ano e apenas 59 em dezembro. 
Helmut Schwarzer

Gráfico 12 - Igarapé-Açu, Bragantina, Estado do Pará, Brasil e Sul Urbano: Estrutura populacional por faixas etárias, 1991 e projeção (Pará), 2020

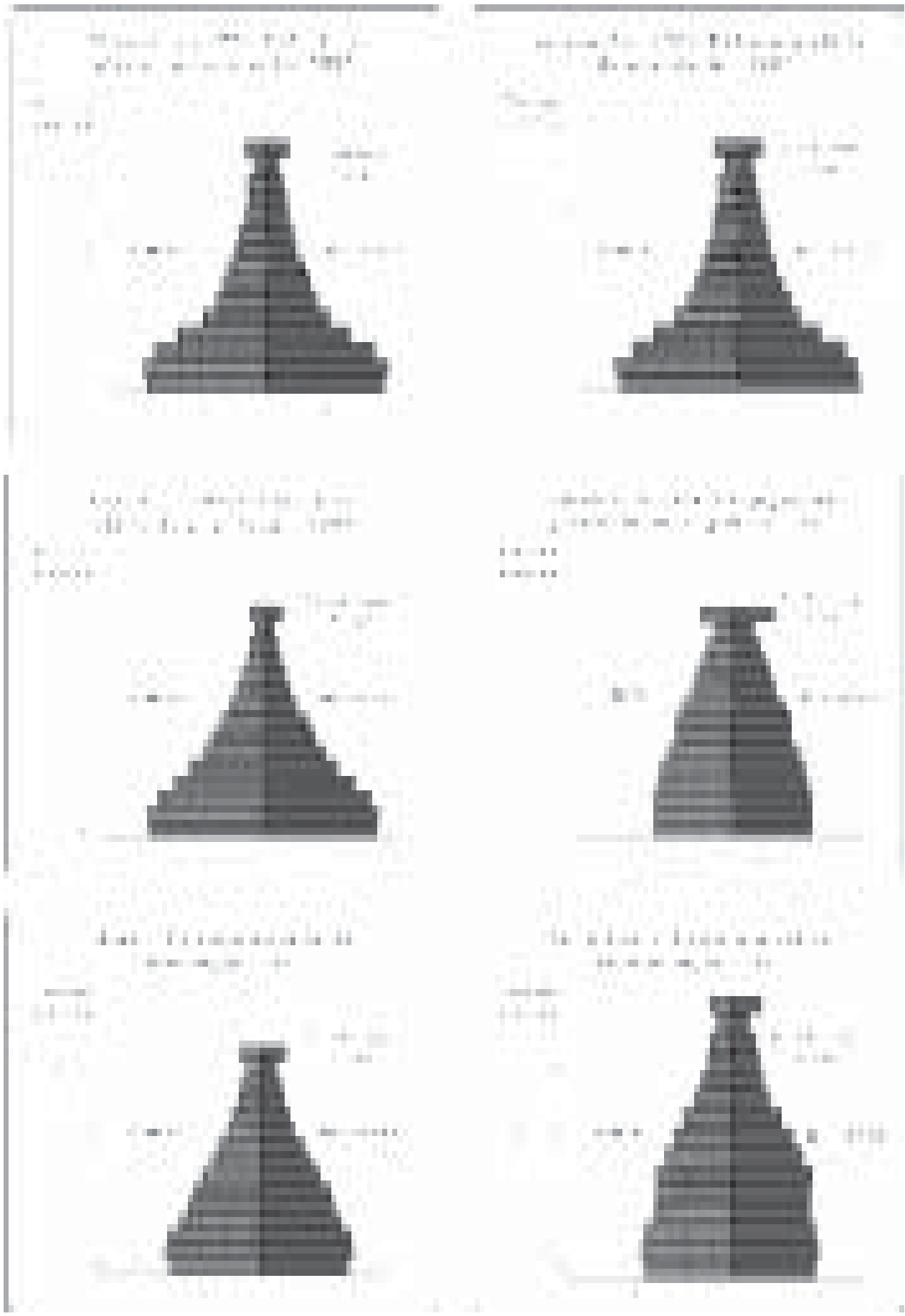

Fonte: IBGE (Censos Demográficos, 1991) 
Tabela 10 - Igarapé-Açu: Número de estabelecimentos declarantes da RAIS e número de empregados formais por setor de atividade e tamanho do sstabelecimento, em 31.12.1995

\begin{tabular}{|lccccccc|}
\hline & Estabelecimentos & \multicolumn{7}{c|}{ Número de empregados portamanho do estabelecimento } \\
\hline Setores de atividade & declarantes daRAIS & $1 \mathrm{a} 4$ & $5 \mathrm{a} 9$ & $10 \mathrm{a} 19$ & $20 \mathrm{a} 99$ & $100+$ & Total \\
\hline Administração Pública & $1-$ & - & - & - & 206 & 206 & \\
Agricultura & 9 & 11 & 7 & 15 & - & - & 33 \\
Alimentosebebidas & 1 & 1 & - & - & - & - & 1 \\
Comércio varejista & 9 & 10 & 7 & 13 & - & - & 30 \\
Institutus financeiros & 2 & - & 14 & - & - & - & 14 \\
Madeira emobilírio & 1 & 4 & - & - & - & - & 4 \\
Medicina, Odontol., Veterin. & 2 & 4 & - & - & - & - & 4 \\
Serviços de Utilidade Pública & 2 & 4 & - & 17 & - & - & 21 \\
Transportese comunicações & 2 & 4 & - & - & - & - & 4 \\
Outros/lgnorados & 9 & 11 & 15 & - & 33 & - & 59 \\
Total & 38 & 49 & 43 & 45 & 33 & 206 & 376 \\
\hline
\end{tabular}

Fonte: Ministério do Trabalho (Relação Anual de Informações Sociais - RAIS, 1995).

A massa salarial paga no mercado de trabalho formal de Igarapé-Açu, pela Prefeitura Municipal não é a maior do município (vide Tabela 12). Contudo, somando-se as remunerações pagas pela Prefeitura e pelos Institutos Financeiros, chega-se a mais da metade da massa salarial formal do município em dezembro de 1995 (Conf. Tabela 11).

Embora os dados da RAIS não representem o mercado de trabalho total do município e também não possam ser tomados como plenamente acurados, eles fornecem um forte argumento a favor da hipótese da grande importância do sistema de benefícios rurais para a dinamização da economia municipal de Igarapé-Açu ao se comparar a massa salarial formal mensal de 815,5 salários mínimos em dezembro de 1995 com o número de benefícios rurais pagos pelo INSS. Estes atingiram em 1995, de acordo com dados da DATAPREV/Síntese, a média de 2.660 benefícios mensais emitidos em Igarapé-Açu, no valor de um salário mínimo cada.

Ou seja, de acordo com os dados disponíveis, a Previdência Rural foi responsável em 1995 pela injeção na economia municipal de uma soma equivalente a mais de três vezes o valor da folha salarial formal de Igarapé-Açu. Uma outra comparação possível seria entre a massa de transferências efetuadas pela Previdência Rural e o valor de produção das lavouras segundo o IBGE. Em 1997 este correspondeu a R\$ 19,3 milhões, o que resulta em uma média de 13.407,6 salários mínimos mensais. Contando que os benefícios rurais são pagos 13 vezes ao ano, o valor transferido pelos benefícios rurais a Igarapé- 
Açu corresponde a grosso modo, a pouco mais de um quinto $(21,5 \%)$ do valor da produção de lavouras do município. Esses dados corroboram a importância econômica do sistema de aposentadorias rurais no município e sublinham que, se a percepção de benefícios rurais estivesse estreitamente ligada à contribuição de cada segurado, tal qual planejado para o subsistema urbano, a taxa de cobertura do sistema previdenciário cairia dramaticamente.

Tabela 11 - Igarapé-Açu: Massa salarial e remuneração média em salários mínimos dos empregados de empresas declarantes da RAIS, por setor de atividade em 31.12.1995

\begin{tabular}{|lrrr|}
\hline Setores de atividade & $\begin{array}{c}\text { Massa salarial } \\
\text { em dezembro }\end{array}$ & $\begin{array}{c}\text { Número de } \\
\text { empregados }\end{array}$ & $\begin{array}{c}\text { Remuneração } \\
\text { média }\end{array}$ \\
\hline Administração Pública & 215,34 & 206 & 1,05 \\
Agricultura & 42,95 & 33 & 1,30 \\
Alimentos e bebidas & 1,33 & 1 & 1,33 \\
Comércio varejista & 43,93 & 30 & 1,46 \\
Institutos financeiros & 220,49 & 14 & 15,75 \\
Madeira e mobiliário & 4,00 & 4 & 1,00 \\
Medicina, Odontologia, Veterinária & 5,50 & 4 & 1,38 \\
Serviços de Utilidade Pública & 133,82 & 21 & 6,37 \\
Transportes e comunicações & 38,41 & 4 & 9,60 \\
Outros/lgnorados & 109,73 & 59 & 1,86 \\
Total & 815,50 & 376 & 2,17 \\
\hline
\end{tabular}

Fonte: Ministério do Trabalho (RAIS 1995).

Impacto das aposentadorias rurais sobre os domicílios

Fez-se um levantamento dos benefícios mantidos em Igarapé-Açu com base nos dados administrativos do Posto de Benefícios de Castanhal. Esse mapeamento consistiu na montagem de uma amostra com dados caracterizadores do benefício e do beneficiário no caso de 10 por cento dos cartões individuais dos 3.401 benefícios mantidos.

Com base nessa amostra construiu-se a Tabela 12, onde está a estrutura relativa do estoque de todos os benefícios continuados mantidos pelo INSS em Igarapé-Açu em maio de 1998, incluindo os benefícios urbanos. Ressalta que mais de 4/5 dos benefícios mantidos correspondem ao subsistema rural, com destaque para a aposentadoria por idade. Já entre os benefícios urbanos, são proporcionalmente mais freqüentes as pensões e as aposentadorias por tempo de serviço. A distribuição dos benefícios por gênero também difere entre os dois subsistemas: enquanto no urbano são muito mais freqüentes os beneficiários masculinos (o que se explica pela inserção predominantemente masculina no mercado de trabalho formal), o subsistema rural mantém muito mais prestações a mulheres do que a esse último fato, além de se explicar em parte porque as mulheres podem aposentar-se 5 anos mais cedo e terem expectativa de sobrevida maior, demonstra que o 
acesso feminino aos benefícios pelos critérios de atividade laboral definidos para a aposentadoria rural por idade é mais igualitário e universalizado. Surpreende o baixo número de auxílios-doença (para ambos os gêneros) e de aposentadorias por invalidez (para mulheres).

Por fim, cabe sublinhar na Tabela 12 ainda o volume expressivo de benefícios de caráter assistencial (rendas mensais vitalícias e amparos assistenciais-LOAS). Principalmente os amparos assistenciais para pessoas portadoras de deficiência têm-se expandido fortemente desde a sua implantação em 1996, o que pode dar pistas da dimensão da nova clientela de deficientes sem capacidade de contribuição até recentemente "oculta" às estatísticas oficiais na área rural do Brasil.

Evidencia-se na Tabela 13 que a maioria do estoque de benefícios rurais, rendas mensais vitalícias e amparos assistenciais pagos em Igarapé-Açu em maio de 1998 foi concedida antes da legislação de 1992 entrar em vigor. Isso deixa inferir que, mesmo antes da expansão da cobertura e do aprofundamento qualitativo do sistema previdenciário rural na década de 90 as aposentadorias rurais já possuíam um papel de destaque na conformação da estrutura socioeconômica municipal. Fica também visível o salto numérico dado pelo estoque de benefícios por ocasião da implementação do novo plano de benefícios da Previdência Social no período de 1992 a 1994, bem como a diminuição rápida do número de concessões de novos benefícios a partir de 1995, quando se concluiu a ampliação da cobertura e o INSS aumentou gradativamente o rigor no exame dos processos de concessão. É interessante observar, também, que a partir de 1992 não houve mais concessões de rendas mensais vitalícias, embora essa modalidade de prestação continuasse mencionada no plano de benefícios até o final de 1995, quando passou a ser substituída, no início de 1996, pelo amparo assistencial.

A idade média dos benefícios rurais do estoque mantido em maio de 1998, ou seja, o tempo médio decorrido desde a concessão dos benefícios é de 9,0 anos para benefícios femininos e de 11,2 anos para benefícios masculinos. Esses valores ainda estão influenciados pela extensão bastante recente do acesso aos benefícios para as mulheres, cujo tempo médio desde a concessão deve tender a crescer e a superar o tempo médio relativo aos benefícios percebidos por homens. No tocante à idade média dos beneficiários rurais, os valores já se apresentam mais de acordo com a realidade demográfica: as beneficiárias femininas têm, em média, 68,8 anos de idade e os beneficiários masculinos, 68,1 anos. Provavelmente a idade média feminina não é mais distanciada da masculina pelo fato de as mulheres terem acesso à aposentadoria a partir dos 55 anos de idade. 
Tabela 12 - Igarapé-Açu: Benefícios de prestação continuada mantidos pelo INSS, por espécie, gênero e setor de atividade do segurado gerador do benefício, maio 1998 - (em \% do total geral)

\begin{tabular}{|c|c|c|c|c|}
\hline Espécie & Setor de ativid. & Feminino & Masculino & Total \\
\hline Aposentadoria por idade & $\begin{array}{l}\text { Comércio } \\
\text { Ferrovia } \\
\text { Serviço Público } \\
\text { Rural } \\
\text { Total }\end{array}$ & $\begin{array}{r}- \\
- \\
- \\
34,4 \\
34,4\end{array}$ & $\begin{array}{r}0,6 \\
0,6 \\
0,3 \\
26,5 \\
27,9\end{array}$ & $\begin{array}{r}0,6 \\
0,6 \\
0,3 \\
60,9 \\
62,4\end{array}$ \\
\hline $\begin{array}{l}\text { Aposentadoria por tempo } \\
\text { de Serviço }\end{array}$ & $\begin{array}{l}\text { Comércio } \\
\text { Indústria } \\
\text { Ferrovia } \\
\text { Total }\end{array}$ & $\begin{array}{r}0,6 \\
- \\
- \\
0,6\end{array}$ & $\begin{array}{l}0,6 \\
0,3 \\
0,6 \\
1,5\end{array}$ & $\begin{array}{l}1,2 \\
0,3 \\
0,6 \\
2,1\end{array}$ \\
\hline Aposentadoria por Invalidez & $\begin{array}{l}\text { Comércio } \\
\text { Indústria } \\
\text { Ferrovia } \\
\text { Serviço Público } \\
\text { Rural } \\
\text { Total }\end{array}$ & $\begin{array}{r}- \\
- \\
- \\
- \\
0,3 \\
0,3\end{array}$ & $\begin{array}{l}0,6 \\
0,3 \\
0,6 \\
0,3 \\
4,7 \\
6,5\end{array}$ & $\begin{array}{l}0,6 \\
0,3 \\
0,6 \\
0,3 \\
5,0 \\
6,8\end{array}$ \\
\hline Pensão para Sobreviventes & $\begin{array}{l}\text { Comércio } \\
\text { Indústria } \\
\text { Ferrovia } \\
\text { Serviço Público } \\
\text { Rural } \\
\text { Total }\end{array}$ & $\begin{array}{r}1,2 \\
- \\
- \\
0,6 \\
13,5 \\
15,3\end{array}$ & $\begin{array}{l}0,9 \\
0,3 \\
0,6 \\
0,6 \\
1,2 \\
3,5\end{array}$ & $\begin{array}{r}2,1 \\
0,3 \\
0,6 \\
1,2 \\
14,7 \\
18,8\end{array}$ \\
\hline Auxílio-Doença & Rural & 0,3 & - & 0,3 \\
\hline Auxílio-Acidente & Indústria & - & 0,3 & 0,3 \\
\hline Renda Mensal Vit. Idade & n.a. & 0,3 & 0,3 & 0,6 \\
\hline Renda Mensal Vit. Invalidez & n.a. & 2,4 & 0,9 & 3,2 \\
\hline Amparo p/ Port. Deficiência & n.a. & 1,8 & 1,2 & 5,3 \\
\hline Benefícios Urbanos & & 2,4 & 7,4 & 9,7 \\
\hline Benefícios Rurais & & 48,5 & 32,4 & 80,9 \\
\hline RMVs e Amparos & & 4,4 & 4,7 & 9,1 \\
\hline Gênero desconhecido & & - & - & 0,3 \\
\hline Total & & 55,3 & 44,4 & 100,0 \\
\hline
\end{tabular}

Fonte: Amostra construída com base nos registros administrativos do INSS (Posto de Benefícios de Castanhal). Eventuais diferenças na somatória de linhas e colunas deve-se a arredondamentos. 
Tabela 13 - Igarapé-Açu: Estrutura do estoque de benefícios rurais, rendas mensais vitalícias e amparos assistenciais (LOAS) por época de concessão, maio de 1998 (em \%)

\begin{tabular}{|lccccc|}
\hline & Benef. rurais & RMVs & Amparos & Total \\
\hline $1972-1991$ & 46,6 & 3,8 & 0,0 & 50,3 \\
$1992-1994$ & 39,7 & 0,0 & 0,0 & 39,7 \\
$1995-1998$ & 4,4 & 0,0 & 5,6 & 10,0 \\
Total & 90,6 & 3,8 & 5,6 & 100,0 \\
\hline
\end{tabular}

Fonte: INSS (Registros administrativos de Castanhal).

Tabela 14 - Igarapé-Açu: Distribuição do estoque de benefícios rurais em manutenção por endereço declarado do beneficiário e gênero - Maio 1998

(em \%)

\begin{tabular}{|lccc|c|}
\hline \multicolumn{4}{c}{ Localização do endereço declarado } & \multicolumn{1}{c|}{ Total } \\
\hline & Sede municipal & Agrovilas & Área rural & \\
\hline Por gênero: & & & \\
Feminino & 58,3 & 54,2 & 51,1 & 55,0 \\
Masculino & 41,7 & 45,8 & 48,9 & 45,0 \\
Total & 100,0 & 100,0 & 100,0 & 100,0 \\
Total por localização & 41,6 & 22,3 & 36,1 & 100,0 \\
\hline
\end{tabular}

Fonte: INSS (Registros administrativos em Castanhal).

Por fim, a Tabela 14 apresenta dados sobre a distribuição espacial dos endereços dos beneficiários rurais no município fornecidos ao INSS. Foram considerados apenas aqueles beneficiários cujos endereços estavam identificáveis nas fichas de registro. Embora seja possível que o endereço declarado não corresponda, em alguns casos, ao local de residência efetivo do beneficiário, na tabela torna-se visível uma certa tendência de os homens beneficiários residirem proporcionalmente mais na área rural do município, enquanto as mulheres residem proporcionalmente mais na sede municipal. 
Helmut Schwarzer

Mapa 1 - Igarapé-Açu: Distribuição espacial dos beneficiários rurais e de benefícios assistenciais, por espécie do benefício e segundo endereço declarado ao INSS, maio 1998

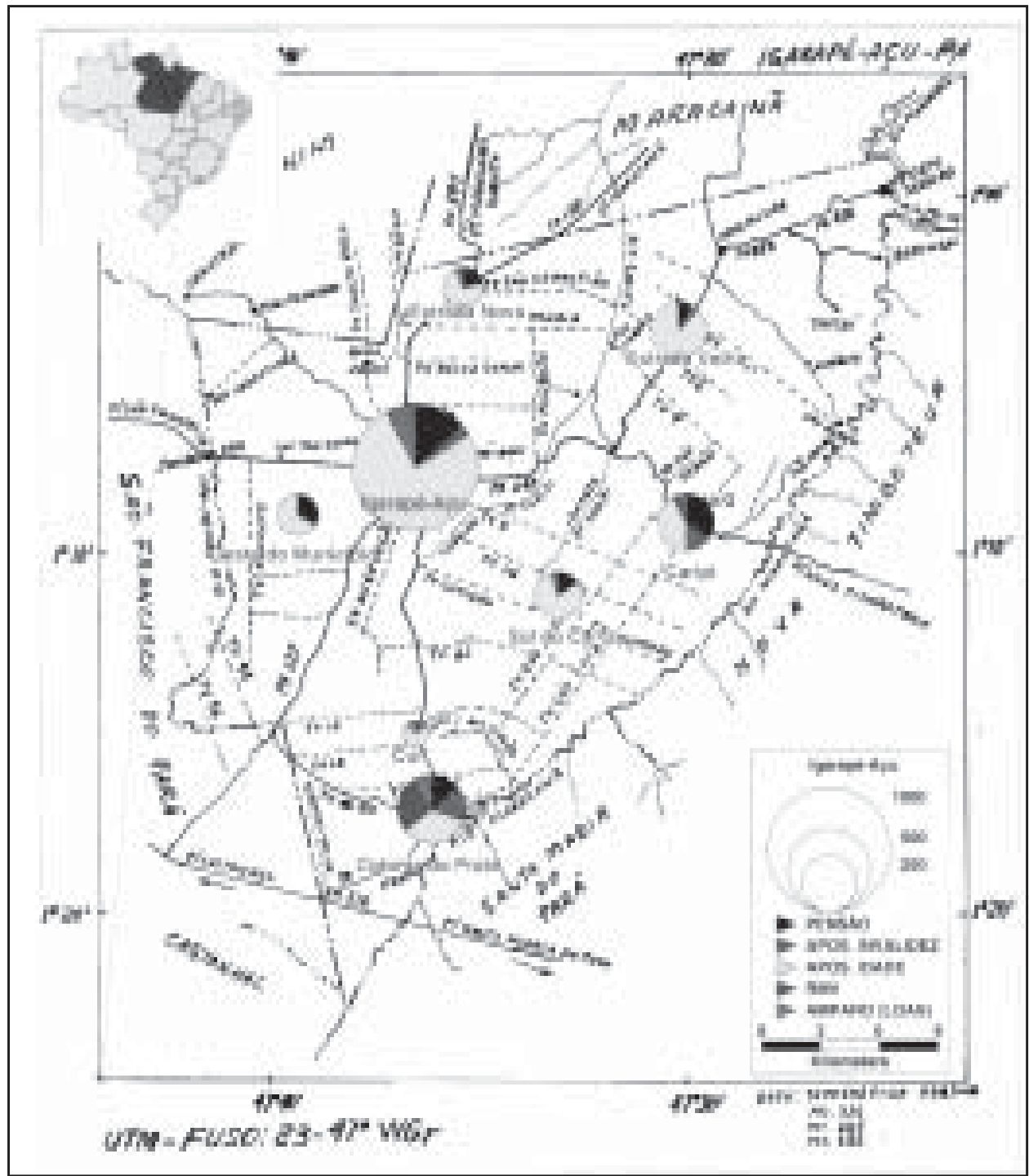

Fonte dos dados brutos: INSS (Posto de Benefícios de Castanhal-PA). Mapa: Francisco Romualdo Souza Filho (NAEA-UFPA). Composição gráfica e georeferenciamento: José Eduardo Sá Malta (IPEA/CGMGI). Apoio técnico: Ney Marshul P. Paes (NAEA-UFPA).

No Mapa 1 mostra-se a distribuição espacial dos beneficiários rurais e assistenciais da amostra levantada para o município de Igarapé-Açu, conforme a declaração de endereço constante nos registros administrativos do Posto de Benefícios do INSS de Castanhal. Essa distribuição espacial pode vir a ser importante como insumo de outros trabalhos que procurem expli- 
car a inter-relação entre o recebimento de transferências monetárias e a adoção de determinado padrão técnico pelos agricultores familiares da área referida (como, por exemplo, Arapiraca et. al., 1999).

Para manter visualizável a distribuição espacial dos beneficiários, eles foram reunidos em oito grupos diferentes, cobrindo várias áreas geográficas do município. Essas áreas foram definidas basicamente de acordo com as áreas de influência desenhadas pelas principais estradas partindo da sede municipal. Na área denominada Oeste do Município estão incluídos os beneficiários das áreas de influência das estradas para Montenegro, Jambu-Açu e da Rodovia Igarapé-Açu-BR 316, bem como da Travessa da Angulação. A área definida como "Sul do Caripi" abrange as longas travessas existentes entre a Estrada para Nova Timboteua (Caripi) e o Ramal do Prata, nas quais não é possível determinar com clareza em qual área de influência os beneficiários residem.

Notam-se dois pólos de concentração de beneficiários - a própria sede municipal e o conjunto Colônia do Prata/Vila Curi. Os grupos da Estrada Velha de Maracanã e da Vila Caripi (São Luiz) também são significativos. Todos possuem uma composição diferenciada por espécie de benefício. Ressalte-se que na Colônia do Prata há um papel muito grande para as Rendas Mensais Vitalícias, os amparos (LOAS) e as aposentadorias por invalidez. Isso decorre do fato de a Colônia do Prata abrigar um centro de tratamento de doentes de hanseníase. Na sede municipal, os amparos (LOAS) têm tido destaque provavelmente pela proximidade do serviço de Assistência Social da Prefeitura, enquanto a área das Estradas Nova e Velha para Maracanã, o Oeste do Município e o Sul do Caripi, ou seja, regiões rurais, possuem uma parcela pronunciadamente alta de benefícios rurais por idade.

\section{Resultados das entrevistas de campo}

As pesquisas socioeconômicas regulares de abrangência nacional, efetuadas pelo IBGE (Censos, Contagem da População, Pesquisas Nacionais por Amostra de Domicílios), não permitem a identificação precisa de beneficiários rurais do INSS, pois os conceitos de "rural" censitário (relacionado ao local do domicílio) e previdenciário (relacionado ao histórico laboral) não coincidem e não há como cruzar os microdados do IBGE com os do INSS. Além disso, as PNADs não abrangem a área rural da Região Norte do Brasil, na qual está localizado o município de Igarapé-Açu.

Os dados específicos dos impactos socioeconômicos das aposentadorias rurais sobre os domicílios dos beneficiários em Igarapé-Açu, foram obtidos por entrevistas baseadas em um questionário padronizado com um grupo de beneficiários. A amostra, escolhida aleatoriamente a partir dos registros administrativos do INSS em Castanhal (Posto de Benefícios que administra os beneficiários do município de Igarapé-Açu), foi um pouco superior a $1 \%$ do total de benefícios creditados pelo INSS em agências bancárias do município de Igarapé-Açu. De uma lista com 50 nomes de benefi- 
ciários, entrevistaram-se 36 pessoas ao longo dos meses de março a maio de 1998. Os benefícios abrangidos na amostra foram aposentadorias rurais por idade, por invalidez, pensões rurais, rendas mensais vitalícias e amparos assistenciais.

O questionário apoiou-se no modelo desenvolvido pelo IPEA, Fundação Joaquim Nabuco e IPARDES para a realização da pesquisa "Avaliação da Previdência Rural", efetuada nas Regiões Sul e Nordeste do Brasil de julho a novembro de 1998. Dessa forma, mantendo-se um conjunto de perguntas de teor semelhante (com algumas adaptações para os propósitos específicos do estudo em Igarapé-Açu), mesmo que se considerem as dimensões muito diferentes de ambas pesquisas, procurou-se conservar a possibilidade de os resultados poderem vir a ser comparados futuramente.

O roteiro de entrevista consistiu em um conjunto inicial de questões, que visavam localizar o entrevistado geográfica e familiarmente. Ao longo da fase de campo, a estas foram acrescentadas três perguntas sobre a origem migratória do entrevistado, seus pais e sobre se é responsável pela criação de netos, uma vez que essas questões mostraram-se relevantes a partir das histórias orais, contadas espontaneamente pelos entrevistados. Um segundo conjunto de perguntas procurou caracterizar o benefício recebido, mapear a história de acesso ao benefício e fatores intervenientes na relação seguradoINSS. O terceiro grupo de indagações teve por objetivo identificar impactos sobre a situação socioeconômica e o comportamento dos beneficiários, relacionado à percepção de um benefício. Quanto aos valores monetários, optouse por solicitar aos entrevistados avaliações aproximadas, checadas por perguntas sobre as demais atividades produtivas e remuneradas eventualmente exercidas por membros da unidade domiciliar do entrevistado. Desta forma evitou-se constrangimentos e contornaram-se os problemas oriundos da dificuldade de manutenção de documentos, que a maioria dos beneficiários, com baixa taxa de alfabetização e condições de moradia pouco favoráveis à conservação de papéis, apresentava.

A distribuição dos beneficiários de aposentadoria rural por idade, aposentadoria rural por invalidez, pensão rural para sobreviventes e rendas mensais vitalícias/amparos assistenciais foi feita conforme a Tabela 15. Destacase que, no universo de entrevistados, há uma preponderância feminina entre os beneficiários de aposentadoria por idade, o que pode facilmente ser explicado, dado que as mulheres podem aceder à aposentadoria em uma idade cinco anos inferior à dos homens e, ao mesmo tempo, possuem uma expectativa de vida mais elevada que a masculina. Também as pensões constituem benefício com supremacia feminina, pela maior expectativa de sobrevida; ademais, a única pensão masculina, parte da amostra, é a de um órfão de 16 anos de idade. Surpreendeu, no entanto, o fato de os benefícios assistenciais captados pela amostra serem exclusivamente masculinos, para o que não se conseguiu explicação lógica, uma vez que os registros administrativos do INSS no Posto de Benefícios de Castanhal apontam uma proporção de beneficiários femininos entre os perceptores de amparos assistenciais de 1/3 e entre os beneficiários da renda mensal vitalícia de 2/3. 
Tabela 15 - Igarapé-Açu: Entrevistados por espécie de benefício e gênero

\begin{tabular}{|lccc|}
\hline & Total & Homens & Mulheres \\
\hline Aposentado por idade & 27 & 11 & 16 \\
Aposentado por invalidez & 1 & 1 & 0 \\
Pensão & 4 & 1 & 3 \\
RMV/Amparo & 4 & 4 & 0 \\
Total & $\mathbf{3 6}$ & $\mathbf{1 7}$ & $\mathbf{1 9}$ \\
\hline
\end{tabular}

Fonte: Pesquisa de campo

A idade média dos beneficiários entrevistados foi de 61,4 anos. Embora ela seja cerca de sete anos menor que a média dos registros administrativos do INSS, é possível que estes últimos sofram de uma sobredeclaração de idade, enquanto na entrevista pessoal os beneficiários declararam sua idade verdadeira. Entre os beneficiários adultos (excluindo-se também os portadores de deficiência), o número médio de filhos e filhas vivos/as declarado foi de 7,2. O número médio de netos e netas vivos/as declarado foi de 12,3. Ambos os valores confirmam o fato, já suspeitado a partir do exame da pirâmide etária de Igarapé-Açu, de que entre as famílias, principalmente rurais, havia até recentemente um papel relevante para um elevado número de filhos nas estratégias de reprodução econômica das famílias. Embora o número de filhos por família tenha diminuído nos últimos anos, essa diminuição ainda está longe de alcançar valores próximos dos do restante do Brasil. Os valores por nós encontrados permitem manter a hipótese de que, para os atuais aposentados, a família extensa ainda desempenha um papel relevante na estratégia familiar.

A escolaridade média declarada pelos entrevistados, de 1,8 série escolar completa, indica terem sido eles submetidos, por sua vez, a estratégias produtivas familiares, tal qual descrito, quando jovens. Em 13 casos (mais de $1 / 3)$, os entrevistados não possuíam nenhum ano de freqüência escolar. A escolaridade máxima encontrada entre os componentes da amostra foi, em somente um caso, de oito séries escolares completas. Percebeu-se, no entanto, que há uma modificação significativa em andamento quanto à reversão desse ciclo causador da baixa escolaridade e à valorização de um maior número de anos de estudo por parte dos netos dos entrevistados. Em parte, os entrevistados justificavam espontaneamente sua baixa escolaridade com a deficiência de infra-estrutura escolar existente "no seu tempo", o que teria mudado comparativamente para melhor, conforme os depoimentos.

O número médio de pessoas moradoras no domicílio do entrevistado, incluindo o próprio, é de 4,8 pessoas, abrangendo filhos, netos e, em alguns casos, outros parentes. Chamou a atenção o número de idosos responsáveis pela criação de netos: 19 disseram ser responsáveis em tempo integral pela criação de ao menos um neto, ao passo que 11 (17 entrevistados menos 2 pensionistas menores de idade e 4 receptores de amparo assistencial) não o são. Certamente este fato é conseqüência da circunstância de que os ido- 
sos, ao receberem um benefício previdenciário, possuem um patamar de renda por vezes superior ao dos filhos, assumindo tarefas destes, para permitir aos filhos a procura e o exercício de trabalho remunerado com maior facilidade, inclusive aqueles que exijam deslocamentos geográficos crescentes.

Embora os entrevistados tivessem declarado, na média, como dependentes exclusivos da renda monetária proporcionada pelo benefício 3,9 pessoas entre aquelas moradoras do domicílio, pode-se argumentar que todos os moradores do domicílio são beneficiados direta ou indiretamente pelo benefício previdenciário. A diferença de 0,9 representa o número médio de pessoas moradoras do domicílio do entrevistado que possuem outra fonte de renda regular (pelo trabalho próprio), a qual, compõe o orçamento doméstico junto com o benefício recebido. Pode-se inferir, portanto, que, no município de Igarapé-Açu, cada aposentadoria rural em média beneficia indiretamente 3,8 pessoas, além do próprio beneficiário direto.

Tabela 16 - Igarapé-Açu: Entrevistados por local de residência e gênero

\begin{tabular}{|lc|c|c|c|}
\hline & Total & Homens & Homens (sem BPC) & Mulheres \\
\hline Sede municipal & 12 & 5 & 3 & 7 \\
Sedes distritais & 11 & 5 & 4 & 6 \\
Área rural & 13 & 7 & 6 & 6 \\
\hline
\end{tabular}

Fonte: Pesquisa de campo.

A distribuição geográfica dos beneficiários entrevistados dentro do município, classificados em três grupos conforme residam na sede municipal, nas sedes distritais ou na área rural (vide Tabela 16), acabou sendo mais homogênea que a colhida nos arquivos administrativos do INSS em Castanhal (vide Tabela 14). No entanto, a tendência de uma menor proporção de pessoas beneficiárias residindo nas sedes distritais está correta. Houve uma sobre-representação de entrevistados moradores na área rural, possivelmente pelo fato de ter sido mais fácil encontrá-los para a realização da entrevista (menor anonimato dos moradores em comunidades rurais) e por deficiências no sistema de endereçamento urbano no município (nomes das ruas confusos). Independentemente desses desvios em relação aos registros administrativos, é possível constatar inequivocamente que há uma proporção maior de mulheres aposentadas residentes nas sedes municipais e distritais do que na área rural, na qual os homens aposentados têm uma participação maior do que sua participação na amostra total.

Na Tabela 17 estão mapeadas as respostas dos entrevistados quanto à sua origem migratória, bem como quanto à origem dos seus pais. 
Tabela 17 - Igarapé-Açu: Entrevistados por condição de migrantes de primeira ou segunda geração

\begin{tabular}{|lcclcc|}
\hline \multicolumn{3}{c}{ Entrevistados } & \multicolumn{3}{c|}{ Pais dos entrevistados } \\
\hline \multicolumn{1}{c}{ Condição } & Absol. & $\%$ & \multicolumn{1}{c|}{ Condição } & Absol. & $\%$ \\
a. Foi migrante & 21 & 58,3 & d. Foram migrantes & 8 & 22,2 \\
& & & e. Não foram migrantes & 9 & 25,0 \\
& & & f. Não respondeu/não soube 4 & 11,1 \\
b. Não foi migrante & 14 & 38,9 & g. Foram migrantes & 9 & 25,0 \\
C. Não respondeu & 1 & 2,8 & h. Não foram migrantes & 5 & 13,9 \\
& & & i. Não respondeu/não soube 1 & 2,8 \\
Total & 36 & 100,0 & & 36 & 100,0 \\
\hline
\end{tabular}

Fonte: Pesquisa de campo

Ressalta que apenas 1/6 dos entrevistados (condições h e i) não possuem uma origem migratória de primeira ou segunda geração. Um detalhamento das perguntas, no entanto, mostra algumas nuances importantes entre os migrantes de primeira e os de segunda geração. Enquanto as migrações dos pais dos entrevistados em geral referem-se a migrações de longa distância, interestaduais - com destaque para os Estados do Piauí, Ceará e Rio Grande do Norte como pontos de origem -, as migrações dos entrevistados propriamente restringiram-se a movimentações dentro do Estado do Pará e, em especial, às áreas de fronteira antiga, com poucos casos em que a origem migratória aponta para municípios distantes mais do que cerca de 150 a 200 quilômetros de Igarapé-Açu. Pode-se identificar, a partir desses indicativos, uma tendência a um perfil demográfico dos beneficiários rurais cada vez menos marcado por migrantes de longa distância, uma vez que a ocupação da terra está plenamente consolidada em Igarapé-Açu.

Tabela 18 - Igarapé-Açu: Entrevistados conforme mudaram de casa após passar a receber o benefício

\begin{tabular}{|lcl|}
\hline & Quantidade & \multicolumn{1}{c|}{ Observação } \\
\hline Mudou & 9 & $\begin{array}{l}\text { Motivos principais: acompanhar filhos e procurar } \\
\text { melhorar a própria infra-estrutura pessoal. }\end{array}$ \\
Não mudou & 27 & $\begin{array}{l}\text { Muitos construíram uma casa de material durável no } \\
\text { mesmo local em que residiam. }\end{array}$ \\
\hline
\end{tabular}

Fonte: Pesquisa de campo

Na Tabela 18, são destacados os movimentos migratórios após a concessão da aposentadoria. Apenas uma das entrevistadas mudou-se para Igarapé-Açu após a aposentadoria, vinda de um município da região do Salgado. Os demais entrevistados já residiam no município antes de solicitarem o be- 
nefício. Percebe-se, em geral, entre os entrevistados uma tendência a permanecer no seu lote rural ou no seu local de residência anterior à aposentadoria, ao menos enquanto as condições de saúde dos entrevistados permitirem. Essa hipótese é corroborada pelo fato de que, conforme depoimento de exvizinhos ou parentes, dos nomes constituintes da relação original obtida no INSS (50 nomes), a maioria das pessoas não mais encontradas em Igarapé-Açu mudou-se para municípios maiores (Castanhal, Ananindeua e Belém) quase exclusivamente por motivo de saúde, à procura de tratamento médico mais específico. Pode-se supor que, se os serviços de saúde do Município de Igarapé-Açu fossem mais completos (no momento restritos a quatro postos de saúde rurais e um hospital para casos de emergência e de maternidade), possivelmente uma parte das pessoas que deixaram o município ali teria permanecido. Um outro movimento, não solidificado devido ao pequeno número de depoimentos verificados (apenas 2), mas curioso e digno de ser citado, é o de idosos aposentados que, tendo mudado para a "rua" (a sede municipal), retornam ao seu lote no campo após algum tempo, devido ao custo de vida mais elevado na área urbana. Esse diferencial de custo de vida foi explicado pelos dois entrevistados com a existência de contas de água e luz, aluguel e eventualmente IPTU a serem pagos na sede municipal - o que tinha impacto significativo sobre o orçamento doméstico dos beneficiários.

É também interessante relatar que os beneficiários procurados para a entrevista na localidade eram dominantemente os proprietários das casas feitas de material de construção durável, em meio a residências de palha, barro ou taipa. Esse fenômeno é atribuível à circunstância de que é o benefício da Previdência que proporciona aos aposentados rurais os recursos monetários necessários para a aquisição dos materiais duráveis (telhas, tijolos, cimento), antes fora do alcance do orçamento doméstico dos agricultores, sob a permanente restrição de fluxos monetários irregulares. Reforça o argumento acima o fato de que muitos dos entrevistados respondiam, quando perguntados se a aposentadoria viabilizou alguma aquisição antes não financiável, que a percepção do benefício permitiu-lhes construir uma casa nova. Dessa forma, as aposentadorias rurais proporcionam aos seus beneficiários um salto qualitativo nas suas condições de habitação, ao menos na área rural de Igarapé-Açu.

Tabela 19 - Igarapé-Açu: Entrevistados por condição de prestação de ajuda financeira a outras pessoas

\begin{tabular}{|lcccc|}
\hline Auxílio a: & & Motivo principal & \multicolumn{2}{c|}{ Sexo do benef. } \\
\hline & & & masc. & fem. \\
\hline Filhos/netos & 16 & Desemprego & 8 & 8 \\
Parentes de $2^{\circ}$ grau & 2 & Desemprego & 1 & 1 \\
Empregados & 1 & Empréstimo & 1 & - \\
Vizinhos & 1 & Empréstimo & - & 1 \\
Não ajuda & 16 & - & 7 & 9 \\
\hline
\end{tabular}

Fonte: Pesquisa de campo 
A Tabela 19 originou-se da hipótese de que os aposentados rurais pudessem ser uma fonte de crédito informal nas suas comunidades. Essa hipótese parece poder ser plenamente descartada, uma vez que os dois únicos casos de empréstimo são o de um agricultor relativamente capitalizado, que faz empréstimos aos seus funcionários (adiantamentos de salário), e o de uma aposentada, que ajuda com pequeníssimas quantias sua vizinhança a "fechar a conta" da "taverna" (compra de alimentos). Em ambos casos não se constatou cobrança de juros ou equivalente. O que surpreendeu, no entanto, foi o elevado quociente de entrevistados que afirmou ajudar filhos, netos e outros parentes com dinheiro em caso de desemprego.

Como já mencionado há, no Brasil, pouco conhecimento sobre a evolução e a dinâmica do desemprego na área rural, já que as principais pesquisas estão restritas aos grandes centros metropolitanos. Possivelmente este seja um motivo para o fato de o sistema de seguro-desemprego, existente nos centros urbanos, nunca ter se tornado um objeto de reivindicação política das representações de trabalhadores rurais. Em Igarapé-Açu, conforme o depoimento dos entrevistados, o desemprego tem aumentado nas atividades agrícolas. É comum que os pequenos produtores em regime familiar dediquem parte do seu tempo de trabalho à plantação própria, com a geração de produto comercializável (ou, no caso de muitos idosos, de subsistência), e, eventualmente, complementando a renda monetária familiar com trabalho assalariado temporário nas plantações de pimenta, maracujá e outros produtos com característica de commodities exportáveis (para o exterior ou para outras unidades da federação), conforme os ciclos de cultivo respectivos. Uma explicação possível é que poderia ter havido uma restrição à contratação de novos trabalhadores assalariados nas plantações, por motivo aqui desconhecido (um dos entrevistados relatou que está em expansão a prática da subcontratação de mão-deobra pelos fazendeiros junto a "gatos" de outras cidades, pressionando o nível de remuneração de Igarapé-Açu, que se encontrava na época das entrevistas em aproximadamente $\mathrm{R} \$ 4,00 /$ dia de trabalho em atividades agrícolas manuais). Pode estar havendo também uma pressão de oferta de mão-de-obra, medida que a volumosa população jovem, identificada no Censo de 1991, ingressa na força de trabalho. Essas circunstâncias fazem os desempregados recorrerem, na ausência de alguma forma específica de seguro-desemprego rural, à renda monetária proporcionada pela aposentadoria rural aos idosos existentes na sua família. Com isso pode-se explicar o número elevado de entrevistados (18 pessoas ou 50\%), que responderam na Tabela 19 que auxiliavam filhos ou parentes em caso de desemprego, uma situação que permitiria supor que a transferência monetária representada pelos benefícios previdenciários rurais acaba assumindo parcialmente a função de um seguro-desemprego familiar, ao menos no município de Igarapé-Açu.

Na Tabela 20 mostra-se o número de benefícios percebidos por domicílio. É importante ter em mente que não apenas é possível que, além do entrevistado, o seu cônjuge ou outro morador possa estar recebendo benefício, mas também é permitido, por exemplo, que uma aposentadoria por 
idade ou invalidez seja acumulada com uma pensão por uma mesma pessoa. Conforme os dados da amostra, em mais da metade das entrevistas (55,6\%), havia a percepção de dois benefícios no domicílio de residência do entrevistado, sendo a ampla maioria dos casos constituída por mais uma aposentadoria por idade do respectivo cônjuge ou, na minoria, por aposentadas por idade percebendo pensão devido ao falecimento do marido. Em uma entrevista, apresentaram-se três benefícios no mesmo domicílio, onde duas aposentadorias por idade apareciam numa família com filho portador de deficiência (percebendo um amparo assistencial). Nos outros 15 casos (41,7\%), o/a entrevistado/a era o único beneficiário residente no domicílio.

Tabela 20 - Igarapé-Açu: Entrevistados por número de benefícios recebidos por moradores no domicílio do entrevistado

\begin{tabular}{|c|c|}
\hline Número de benefícios no domicílio & Número de domicílios \\
\hline 1 & 15 \\
2 & 20 \\
3 & 1 \\
\hline
\end{tabular}

Fonte: Pesquisa de campo

Tabela 21 - Igarapé-Açu: Entrevistados conforme a proporção entre o valor do(s) benefício(s) recebido(s) e as outras fontes de renda monetária familiar

\begin{tabular}{|l|c|c|c|}
\hline $\begin{array}{l}\text { Percentual da renda familiar equivalente } \\
\text { ao(s) benefício(s) recebido(s) }\end{array}$ & Absoluto & Percentual & Acumulado \\
\hline Igual a 100\% & 14 & 38,9 & 38,9 \\
Entre 66,6 e 99,9\% & 11 & 30,6 & 69,5 \\
Entre 50,0 e 66,5\% & 4 & 11,1 & 80,6 \\
Aproximadamente 50\% & 3 & 8,3 & 88,9 \\
Entre 33,3 e 49,9\% & 3 & 8,3 & 97,2 \\
Entre 0 e 33,2\% & 1 & 2,8 & 100,0 \\
\hline
\end{tabular}

Fonte: Pesquisa de campo

A Tabela 21 é fundamental para avaliar-se o impacto do sistema de benefícios rurais da Previdência Social (bem como dos amparos assistenciais) sobre a renda monetária das famílias. A hipótese original deste trabalho - a saber: de que os benefícios monetários possuem um peso significativo na disponibilidade de renda das famílias receptoras na área rural de Igarapé-Açu - pôde ser plenamente constatada. Para 38,9\% dos domicílios dos entrevistados, o valor do(s) benefício(s) recebido(s) constitui a única fonte de renda monetária dos moradores e, no acumulado, para 88,9\% dos domicílios, o sistema de aposentadorias rurais perfaz cerca de 50\% ou mais da renda monetária familiar. O caso do único entrevistado que declarou que a aposentadoria representa uma parcela muito reduzida da sua renda monetária familiar é aquele do agricultor capitalizado, cliente assí- 
duo da carteira de empréstimos da agência local do Banco do Brasil e que possui plantios de maracujá e pimenta, financiados por recursos do Fundo Constitucional do Norte (FNO-Especial). Esse agricultor somente não conseguiu aposentar-se por tempo de serviço urbano devido a um descuido na realização das suas contribuições previdenciárias na categoria de autônomo. Os outros três entrevistados, que responderam ser a aposentadoria uma parcela inferior a 50\% da sua renda monetária, residem em grandes famílias, e os seus filhos, tendo freqüentado a escola por períodos mais longos que a média local, estavam empregados no mercado de trabalho urbano de Igarapé-Açu ou Castanhal.

No entanto, é importante lembrar que esses três últimos casos embora configurem domicílios que, localmente, usufruem de uma situação socioeconômica comparativamente sólida, certamente não representam aposentados "privilegiados", quando colocados lado a lado com os aposentados urbanos mais bem situados. Os empregos, que os seus filhos exercem, estão no patamar de empregos urbanos pouco qualificados (em um dos casos, por exemplo, uma das filhas é empregada doméstica e transfere parte da sua remuneração aos pais e irmãos menores; em outros casos, os filhos eram serventes, trabalhadores braçais ou empregados no comércio). Essa ressalva parece importante para evitar julgamentos precipitados quanto a uma eventual "falta de precisão" da "focalização" do sistema de aposentadorias rurais "nos mais pobres". Quando colocado em um contexto mais amplo, o resultado obtido nesta amostra corrobora a hipótese de que o sistema de aposentadorias rurais no Brasil parece atingir, com poucas exceções, parcelas populacionais que se encontram entre as destituídas, e há motivos para acreditar que ele está entre os mais eficientes programas de redistribuição ao menos da América Latina.

Quanto à estrutura de gastos dos domicílios dos entrevistados, a grande maioria das despesas, conforme declarações dos beneficiários, dirige-se à aquisição de alimentos na "taverna". Em termos de gastos especiais, verifica-se que, além das recorrentes despesas com algumas melhorias marginais na qualidade da habitação ou da compra de material de construção durável, sobressai o gasto privado com a saúde. Quase dois terços dos entrevistados (21 casos) afirmaram que medicamentos, alimentos especiais e tratamentos médicos específicos, não acessíveis na (modesta) rede local de saúde, consomem parcelas significativas do seu orçamento doméstico. Embora seja de se esperar que a clientela específica dos benefícios analisados - idosos, e portadores de deficiência - apresentem uma demanda acima da média por produtos e serviços relacionados à sua saúde, o resultado acima demonstra, também, que de certa forma o sistema de aposentadorias rurais substitui parcialmente as carências do sistema público de saúde (falta de tratamentos específicos, falta de medicamentos), auxiliando a manter, mesmo que em alguns casos de forma apenas precária, um mínimo de qualidade de vida dos beneficiários, e fazendo acessíveis os medicamentos e serviços de saúde comerciais. 
Tabela 22 - Igarapé-Açu: Entrevistados conforme experimentaram dificuldade de acesso ao benefício e necessitaram de ajuda para a sua obtenção

\begin{tabular}{|lrllll|}
\hline & $\begin{array}{c}\text { Quan- } \\
\text { tidade }\end{array}$ & $\begin{array}{l}\text { Motivo da } \\
\text { dificuldade }\end{array}$ & \multicolumn{2}{l|}{$\begin{array}{l}\text { Necessidade de ajuda } \\
\text { para a obtenção do benefício }\end{array}$} \\
\hline Teve Dificuldade & 18 & $\begin{array}{l}\text { Documentação } \\
\text { incompleta (9), } \\
\text { comprovar invalidez } \\
\text { (2) outros (7) }\end{array}$ & Fonte da ajuda & Não \\
STR (6), Vereador (1) & & Prefeitura (1), Outros (8) & 2 \\
Não teve dificuldade & 18 & - & STR (6), Vereador (2) & \\
\hline
\end{tabular}

Fonte: Pesquisa de campo ${ }^{*}$ Um entrevistado não respondeu se precisou de ajuda para obtenção do benefício

A Tabela 22 cruza informações de dois conjuntos de questões dirigidas aos entrevistados. Por um lado, a metade dos entrevistados afirmou que não teve dificuldade para conseguir o acesso ao benefício na época do requerimento. Por outro lado, no entanto, entre esses dezoito entrevistados, quatorze disseram que necessitaram de ajuda para poder aposentar-se. É possível afirmarse que a dificuldade de obtenção do benefício refere-se a eventuais obstáculos representados pelos procedimentos administrativos no INSS. Assim, o grupo que respondeu que não enfrentou dificuldade esperou em média 4,7 meses desde o requerimento até a concessão do benefício, enquanto o grupo que enfrentou obstáculos afirmou que o benefício demorou 7,1 meses para ser concedido. Além disso, as pessoas que dizem ter enfrentado obstáculos são, com apenas uma exceção, beneficiários que, para a obtenção do benefício, tiveram que realizar várias viagens à "rua", a Castanhal (ao Posto de Benefícios do INSS, para entrevistas e perícias médicas) e a Belém (para a obtenção de documentos ou a realização de perícias muito especializadas), o que representou considerável esforço financeiro, dado que o preço das passagens de ônibus (mais a alimentação na cidade) é bastante elevado, quando comparado com a renda familiar monetária disponível. Afora isso, o tempo de trabalho despendido para realizar essas viagens (sempre acompanhado de cônjuge e/ou filho/a) implica sensível perda de tempo de trabalho na lavoura, além do desgaste físico para os idosos e portadores de deficiência.

Entre os principais motivos causadores da dificuldade, foram citados, em primeiro lugar, a falta de documentos (documento de identidade, CPF, documentação do terreno) - o esforço de obtenção desses documentos, em um dos casos, chegou a demorar quase um ano -, dificuldades em comprovar a invalidez na perícia realizada no INSS e outras, havendo um caso de alegada demora do trâmite no INSS e outro de falta de conhecimento da beneficiária do seu direito ao benefício. 
Entre os entrevistados que responderam não terem enfrentado dificuldades de obtenção do benefício, há a concentração de muitos beneficiários que obtiveram a concessão do seu benefício nos anos 1992 a 1994, quando a nova legislação para as aposentadorias rurais foi implementada. Já o grupo que diz ter sofrido maiores obstáculos possui várias pessoas que se aposentaram em períodos de concessão mais distantes, no início dos anos 80, e bem recentes, quando o INSS passou a atuar com mais rigor na concessão de benefícios, em especial quanto ao exame da documentação requerida (passando a exigir a documentação do terreno, cuja expedição custa R\$ 8,50 no cartório local e que, conforme a proprietária do cartório, "pouquíssimas pessoas possuem").

Mesmo entre os beneficiários com pouca ou nenhuma dificuldade de obtenção da prestação, no entanto, 14 dizem ter sido necessária a ajuda de alguém para poder vencer os diversos passos do procedimento necessário, incluindo a obtenção de informações, a compilação da documentação requerida e o preenchimento dos formulários respectivos. A entidade/pessoa mais citada entre todos os entrevistados como fonte de auxílio foi o Sindicato dos Trabalhadores Rurais (12 casos), seguido da Prefeitura Municipal via Serviço de Assistência Social (3 casos), um determinado vereador (3 casos) e outros (11 casos), incluindo um juiz, o agente de correio, familiares, vizinhos, conhecidos ou professores/as das escolas locais.

Os benefícios têm sido pagos todos os meses de forma extremamente pontual nos dias previamente marcados, conforme todos os entrevistados. O saque ocorre nas duas agências bancárias existentes na sede municipal com o uso de cartões magnéticos por todos os beneficiários. Essa conta com cartão magnético, específica para movimentações relativas a benefícios do INSS, é criada automaticamente no momento da concessão do benefício. Em um dos dias da escala de pagamentos, organizada conforme o número final do benefício, o beneficiário ou seu representante dirige-se à agência bancária respectiva, onde o horário de atendimento das 8:00 às 10:00 horas (antes, portanto, do horário comercial normal do banco) é destinado exclusivamente ao atendimento de beneficiários do INSS. Os beneficiários, em função dos horários de ônibus que os trazem das agrovilas e da área rural, chegam à praça central da cidade a partir das 5:30-6:30 horas da manhã, retornando, após a realização do saque e feita a "feira" (compra de mantimentos nos mercados da "rua") a partir das 11:00 horas aproximadamente, quando é o horário de retorno dos ônibus. As empresas de ônibus têm orientado os seus motoristas a permitir o embarque de aposentados com grandes volumes de bagagens, em especial nos dias do saque do benefício (por exemplo, botijões de gás). O saque do benefício é feito no caixa eletrônico, havendo para tanto a necessidade da presença de um funcionário do banco para auxiliar os idosos a operar corretamente o equipamento.

A distância do domicílio até o local de pagamento - as duas agências bancárias existentes na sede municipal - é, na média, de 17 quilômetros para aqueles que residem na área rural ou nas agrovilas. O tempo de deslocamento médio para essas pessoas, para poderem a sacar o benefício, foi de 
5,7 horas. O caso mais extremo verificado foi o de um aposentado que, residindo a 24 quilômetros da sede municipal, precisava gastar cerca de 11 horas para realizar o saque do benefício.

Não foi constatado, ao longo das entrevistas, que fosse característico, por ocasião da concessão do benefício, fazer-se a transferência da responsabilidade pela gestão da unidade produtiva rural aos filhos dos aposentados. Apenas 6 de 30 entrevistados (exceto pensões e amparos) disseram que os filhos assumiram a propriedade da família. Na realidade, essa transferência de responsabilidade formal pela continuidade das atividades da unidade de produção rural, que é o motivo clássico a justificar a instituição de um sistema de aposentadorias rurais na Europa, nunca esteve presente como condicionante para a concessão do benefício dentro do programa brasileiro.

Entre os entrevistados, ao contrário do que seria de se esperar devido à maior experiência de vida e liderança dos idosos em seus respectivos meios sociais, houve um nível bastante baixo de participação comunitária por intermédio de associações e demais organizações sociais. Apenas quatro entrevistados responderam que participavam ativamente dos eventos e mesmo por meio de cargos de responsabilidade nas suas respectivas entidades comunitárias e em cooperativas. Duas pessoas disseram participar ativamente da sua Igreja (aliás, verifica-se um processo acelerado de expansão de seitas pentecostais em Igarapé-Açu, com a construção de novos templos, além dos vários já existentes). Quanto ao Sindicato de Trabalhadores Rurais, embora o número de respostas tenha sido elevado (quinze declarações espontâneas), a grande maioria dos entrevistados referia-se ao fato de pagar a contribuição solidária ao Sindicato Rural, sem que efetivamente houvesse uma participação regular em assembléias e demais atividades do sindicato.

Na Tabela 23 analisa-se mais detalhadamente o perfil dos entrevistados conforme sua resposta à pergunta se o beneficiário continua trabalhando. Percebe-se, inicialmente, que, após feita a subtração dos dois menores de idade beneficiários de pensão por morte e dos quatro perceptores de benefício assistencial em virtude de deficiência, há um equilíbrio entre as respostas positiva e negativa à questão. Procurou-se verificar se os dois grupos de respondentes diferenciavam-se pela sua idade média, mas não parece que a resposta seja devida a uma idade média significativamente mais avançada do grupo que não prossegue trabalhando. Tampouco parece haver diferenciação relevante quanto ao número de dependentes do benefício, o que poderia ter imposto uma maior pressão sobre o beneficiário para que continuasse trabalhando. Também não há praticamente nenhuma diferença entre ambos os grupos quanto à proporção que a(s) aposentadoria(s) perfaz(em) da renda monetária da unidade doméstica em questão, o que poderia ser o contrateste da afirmação anterior. 
Tabela 23 - Igarapé-Açu: Entrevistados segundo continuação da atividade de trabalho e outras condiçôes

\begin{tabular}{|c|c|c|}
\hline Prossegue trabalhando: & Sim & Não \\
\hline & 15 & $15^{\star}$ \\
\hline Idade média do beneficiário & 69,5 & 70,4 \\
\hline $\mathrm{N}^{\circ}$ de dependentes do benefício & 3,8 & 4,4 \\
\hline Proporção aposentadoria/renda monetária familiar** & 2,3 & 2,5 \\
\hline Ajuda financeiramente filhos/netos & 9 & 7 \\
\hline Ajuda financeiramente outras pessoas & 3 & 0 \\
\hline Não ajuda financeiramente outras pessoas & 3 & 8 \\
\hline Homens & 10 & 2 \\
\hline Mulheres & 5 & 13 \\
\hline
\end{tabular}

Fonte: Pesquisa de campo. * 21 entrevistados responderam que não trabalham. Destes foram subtraídos dois menores beneficiários de pensões e 4 beneficiários de amparo assistencial (BPC) para pessoas portadoras de deficiência. ${ }^{* *}$ Numa escala de $1=100 \%$ para $6=0$ a $33 \%$, conforme os segmentos de impacto dos benefícios sobre a renda monetária domiciliar da Tabela 22 .

Quanto à prática de conceder ajuda financeira para fora do domicílio, apenas entre os que não auxiliam ninguém houve uma diferença significativa. Por fim, a diferenciação mais precisa foi obtida ao cruzar-se as respostas com o sexo dos entrevistados: houve uma clara maioria de homens entre os que afirmam continuarem a trabalhar, enquanto as mulheres disseram na sua grande maioria não mais trabalhar. No entanto, a partir da observação dos hábitos cotidianos das unidades domésticas em análise, permanece a suspeita de que essas respostas por gênero possuem um viés cultural, conforme a definição do papel produtivo que cada sexo faz de si mesmo. Eventualmente as mulheres, embora tenham respondido que não prosseguem trabalhando, continuam cumprindo jornadas de trabalho tão pesadas quanto os homens, executando tarefas auxiliares na produção da unidade agrícola, no trabalho reprodutivo da família e na criação de netos.

A Tabela 24, cruza respostas de duas perguntas que visavam esclarecer se, após a concessão do benefício, os entrevistados obtiveram maior acesso a crédito junto ao comércio local do que antes. Essa hipótese baseava-se no fato de que, conforme declarações de comerciantes do município, os aposentados e as pessoas com emprego regular possuem melhores condições de crédito. Por exemplo, gozavam de um prazo de pagamento de um mês, ao passo que aqueles que não possuíssem renda monetária regular tinham que liquidar suas posições de crédito semanalmente. A tabela não oferece, no entanto, elementos para a afirmação de que os beneficiários utilizam mais intensivamente o crédito após a concessão do benefício, do que na situação anterior. Na realidade, evidencia-se, independentemente da condição de beneficiário do INSS ou não, a compra fiado é um hábito muito difundido entre os agricultores da região. Apenas um sexto dos entrevistados passou a com- 
prar fiado em função da condição de beneficiário, compensado por um grupo de quase igual número de pessoas, que deixou de adotar essa prática, talvez devido ao melhor planejamento dos gastos maior regularidade dos fluxos monetários proporcionada. Um dos entrevistados, residente em área urbanizada, afirmou que concede aval de aluguel aos seus filhos a partir da percepção do benefício.

Tabela 24 - Igarapé-Açu: Entrevistados conforme hábito de fazer compras fiado antes e depois de passar a receber o benefício

\begin{tabular}{|lccc|}
\hline & \multicolumn{3}{c|}{$\begin{array}{c}\text { Comprava fiado antes de passar a } \\
\text { receber o benefício }\end{array}$} \\
\hline & & Sim & Não \\
Compra fiado depois de passar & Sim & 16 & 6 \\
a receber o benefício & Não & 7 & 7 \\
\hline
\end{tabular}

Fonte: Pesquisa de campo.

Uma pergunta final solicitou aos entrevistados uma avaliação subjetiva quanto aos efeitos do benefício sobre a sua vida em geral. Das 34 pessoas que responderam à questão, cinco foram enfáticas em dizer que a sua vida "melhorou muito", a absoluta maioria (28) afirmou que a vida "melhorou um pouco" e apenas um disse que "ficou igual". Nenhum dos entrevistados declarou ter sentido uma piora nas suas condições de vida. Do grupo que disse que a vida "melhorou um pouco" percebe-se, pelos comentários espontâneos dos entrevistados, justificando a gradação dada à resposta, que são as condições extrabenefício, principalmente a deterioração das condições de saúde pessoais, que fazem com que a "vida atual" seja considerada apenas "um pouco melhor". Muitos entrevistados afirmaram, explicitamente, que julgavam que o fator de melhoria em relação a antes devia-se ao fato de o benefício do INSS ser regular e mensal, ao contrário do resultado da produção agrícola. Dessa forma, a aposentadoria parece cumprir com sua função de oferecer a esses beneficiários uma maior "segurança" social, tornando-os menos dependentes do ciclo agrícola e dos seus filhos na velhice.

Entre as declarações livres e explicações, que se seguem quase forçosamente a uma pergunta dessa natureza, destacam-se algumas de cunho religioso. "Deus abençoe a quem criou estas aposentadorias!" Mas também outras, narrando como era o destino dos idosos antes da criação do sistema de aposentadorias rurais. Aqui, as declarações mais típicas eram três: "os idosos trabalhavam até morrer", "os idosos viviam dependendo dos filhos" e "os idosos pediam esmola, quando não tinham filhos a quem recorrer".

\section{Conclusões da pesquisa de campo}

O município de Igarapé-Açu, na Microrregião Bragantina no Nordeste Paraense, é um dos casos no Estado do Pará e na Região Norte, em que os 
significativos impactos do sistema de previdência rural parecem ser mais claramente identificáveis. Essas repercussões, de que já se podia suspeitar apenas pela análise da distribuição espacial dos beneficiários rurais no Estado do Pará, foram corroboradas pela análise de dados de outras fontes secundárias e, principalmente, pelo resultado de um conjunto de entrevistas com cerca de 1\% dos beneficiários do INSS no município.

Verificou-se que, em 1995, o sistema de previdência rural injetou na economia municipal um volume de recursos aproximadamente três vezes superior ao valor da folha de todos os empregadores formais de Igarapé-Açu. Em entrevistas com comerciantes locais, constatou-se que as compras realizadas pelos beneficiários da Previdência Social representavam uma parte pronunciada do faturamento dos respectivos estabelecimentos. Além disso, com base em dados sobre a situação social de Igarapé-Açu, situada no terço inferior do ranking do Índice de Desenvolvimento Humano Municipal (IDHM), é possível dizer que o proporcionalmente vultoso pagamento de benefícios previdenciários no município constitui um elemento de redistribuição inter-regional progressiva da renda.

A proporção que os benefícios previdenciários rurais participam da renda monetária das famílias dos entrevistados também é extremamente significativa. No caso de quase 9/10 (88,9\%) dos entrevistados, o(s) benefício(s) recebido(s) representava(m) cerca de 50\% da renda monetária familiar ou mais. Esse dado também demonstra que, apesar de se tratar de uma política social de acesso universal, o programa de benefícios previdenciários rurais no Brasil possui uma precisão de focalização em pessoas pobres e muito pobres bastante alta, a qual dificilmente é igualada em casos de outros programas sociais em outras partes do mundo de porte comparável à Previdência Rural. Cabe salientar que, no caso de Igarapé-Açu, no domicílio dos beneficiários rurais residem em média mais outras 3,8 pessoas, que se beneficiam indiretamente da transferência monetária.

Descobriu-se, também, que no município de Igarapé-Açu o sistema de benefícios rurais funciona como um substituto parcial para o sistema de seguro-desemprego, o qual, por sua vez, não existe na área rural brasileira. Entre os beneficiários da Previdência Rural entrevistados, 18 (50\%) afirmaram ajudar com dinheiro parentes ou filhos/as em caso de desemprego. Outro efeito positivo sobre a qualidade de vida local é que o acesso à renda monetária permite que os beneficiários adquiram serviços médicos e medicamentos não disponíveis na rede pública de saúde. A percepção de benefícios da Previdência Rural, por fim, parece efetivamente fixar os idosos nos municípios rurais, ao menos até que algum problema de saúde surja ou ocorra a mudança dos filhos, dos quais os idosos dependem para cuidados ou devido ao seu papel social (no caso da mulher), para o meio urbano.

\section{Elementos para uma economia política das aposentadorias rurais}

Uma outra forma de contemplar o sistema de Previdência Rural brasileiro é a partir das teias de interesse formadas ao redor do programa, utili- 
zando-se o prisma da "Nova Economia Política". Essa linha teórica parte do pressuposto de que os atores participantes, modelados como indivíduos egoístas, procuram maximizar individualmente o retorno auferido, o qual não apenas é de caráter financeiro, mas também pode ser a consolidação do poder ou a reeleição de um político, a promoção da carreira de um burocrata e outras (Nitsh, 1980, 1984, 1997). Uma determinada institucionalidade gera incentivos ao comportamento individual maximizador de resultados (ou minimizador de esforços), o que, eventualmente, pode reinstruir o processo de conformação da estrutura de incentivos. O objetivo desta parte do trabalho é apresentar elementos que permitam uma primeira aproximação das estratégias dos principais atores e o levantamento de hipóteses para seu esclarecimento.

Ao redor do sistema de previdência rural gerou-se uma intensa teia de interesses e estruturas sociopolíticas relevantes, dada a dimensão das transferências monetárias envolvidas. O Gráfico 15 nomina os principais atores individuais e institucionais na arena do Sistema de Previdência Rural. Cada um desses atores possui uma estratégia individual, de acordo com o conjunto de objetivos que procura atingir em contato com o sistema de previdência rural. A capacidade de cada ator lograr alcançar seus objetivos depende de sua representatividade política ou da capacidade de conseguir aliar interesses comuns com outros agentes participantes do sistema.

A principal característica do sistema, que influencia fundamentalmente os interesses individuais e arcos de alianças ao redor do sistema, é a sua incapacidade de auto-sustentação financeira e a necessidade de haver um volumoso subsídio para o financiamento dos benefícios rurais. Dessa forma, com um fraco vínculo contributivo individual, configura-se potencialmente um caso de the third party pays, ou seja, o concedente e o beneficiário são diferentes do financiador (contribuinte urbano e Tesouro Nacional). Os financiadores também são os atores que mais interesse poderiam ter em restringir o sistema, tanto na sua profundidade, quanto na sua cobertura ainda mais em um período de forte restrição fiscal e de pressão sobre a área econômica do Governo Federal na busca de alternativas de cortes orçamentários. Já os técnicos do Ministério da Previdência e Assistência Social e do INSS não constituem opositores do sistema de Previdência Rural; entretanto, está fortemente arraigada a idéia de que a percepção de um benefício da "Previdência" exige uma contribuição equivalente na vida ativa e que, na ausência desse vínculo bismarckiano, tratar-se-ia de um "benefício assistencial", cuja administração não deveria caber ao MPAS/INSS. A tentativa de introduzir esse vínculo com algum rigor atuarial, inviabilizaria em grande medida a dinâmica do sistema de Previdência Rural no Brasil. 
Gráfico 15 - Elementos para uma economia política do sistema de previdência rural no brasil

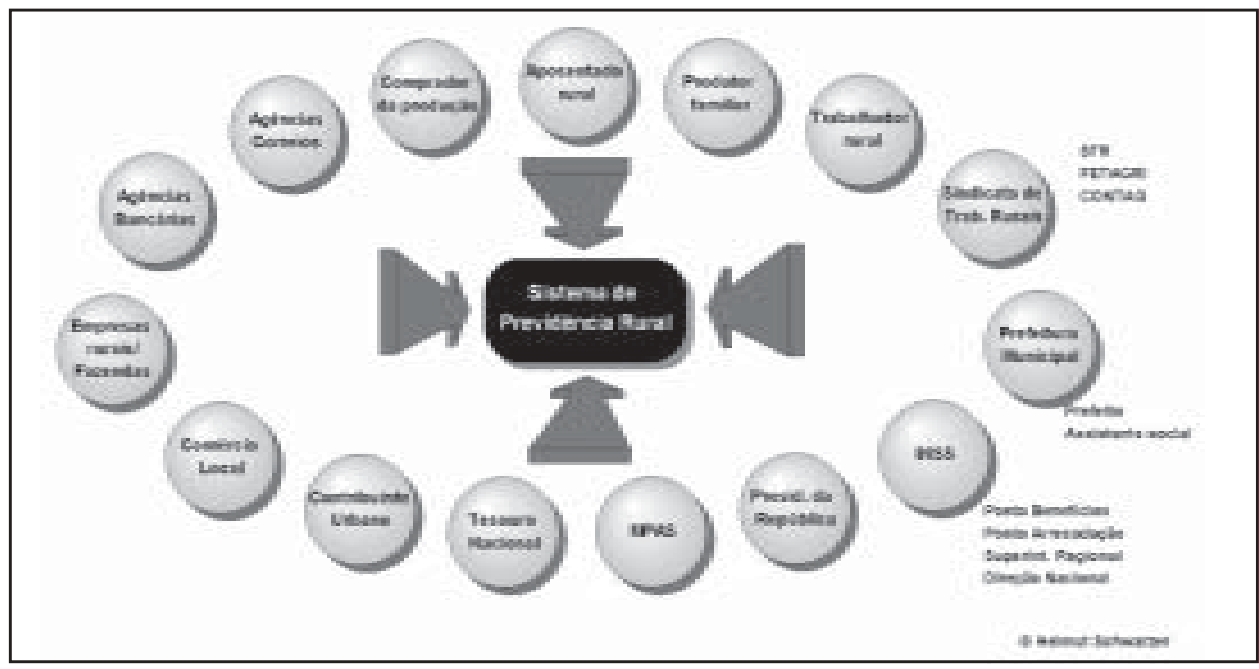

Fonte: Desenvolvimento do autor

Do lado do Governo Federal, por fim, há ainda interesse da Presidência da República, que, ao longo dos anos 1998 e 1999 descobriu o programa previdenciário rural como um amplo programa de redistribuição de renda, em rebater as críticas de que o governo teria priorizado apenas a estabilização econômico-monetária em detrimento do desenvolvimento social. Além disso, seria possível que, à medida que o programa fosse descoberto internacionalmente como sendo um eficiente mecanismo de combate à pobreza, o país e seus dirigentes ganhassem prestígio internacional, sem mencionar um eventual interesse que ainda possa existir em relação a um dos objetivos iniciais do programa nos anos 70, a saber: evitar a migração rural-urbana.

Em uma estrutura de third party pays, há um forte interesse pela expansão do sistema de benefícios não apenas da parte dos próprios segurados especiais e dos seus representantes (Sindicatos de Trabalhadores Rurais), mas também por parte das Prefeituras Municipais ${ }^{13}$ e do comércio local, que obtém proveito com a significativa dinamização da atividade econômica advinda do poder de compra injetado por meio dos aposentados rurais no município.

Foram colhidos, ao longo das entrevistas realizadas no Pará, declarações que sublinham o papel dinâmico das aposentadorias rurais em muitas economias municipais. Indicativo disso é a tentativa de prefeitos de cidades do interior do Pará de concentrar nas agências bancárias de sua cidade o pagamento de benefícios da região, o que tem como efeito um imediato aquecimento de vendas no comércio do município. O contrário

\footnotetext{
${ }^{13}$ Exatamente por isso não seria uma boa recomendação ao Governo Federal que ele permitisse que todas as perícias e comprovações necessárias à autorização de benefícios novos estivessem a cargo de entidades públicas sob controle administrativo e político local.
} 
ocorre com aqueles municípios e distritos municipais, nos quais não há pagamento de benefícios ou em que o pagamento de benefícios foi transferido para outra localidade. Isso se dá pois os aposentados normalmente realizam, junto com o saque mensal da aposentadoria, a sua compra mensal de mantimentos e equipamentos, evitando novos deslocamentos para a cidade. Reportou-se, em uma das entrevistas, o exemplo de uma cidade do sul do Pará, em que as agências bancárias fecharam devido ao excesso de assaltos, a agência dos Correios não podia garantir a segurança do pagamento mensal de aposentadorias e, em conseqüência, os trâmites bancários foram transferidos para outro município. Imediatamente o comércio local sofreu um severo impacto no seu faturamento, o que fez a associação de lojistas local realizar um esforço conjunto para garantir o retorno do pagamento de benefícios previdenciários ao município. Da mesma forma, foi relatado o caso de um distrito do município de Cametá, onde o encerramento de atividades da agência bancária causou profundos prejuízos ao comércio local. Reclamações similares ouviram-se no município de Salinópolis, na região do Salgado Paraense, no qual a única agência bancária havia fechado recentemente no início de 1998.

Um papel bastante peculiar está reservado ao Sindicato dos Trabalhadores Rurais. Por um lado, há evidentemente o interesse na manutenção do sistema previdenciário rural enquanto representante dos trabalhadores rurais, bem como dos produtores familiares rurais ${ }^{14}$. No entanto, além deste acrescenta-se outro motivo: a estrutura sindical rural também se financia por meio de uma contribuição solidária de $2 \%$ paga pelos aposentados rurais - o que faz sentido, uma vez que os ativos não possuem uma renda monetária regular suficiente para garantir uma periodicidade de contribuição, diferentemente dos inativos. Os STRs prestam serviços aos aposentados e, em especial, no momento da solicitação do benefício, quando em geral o produtor familiar recorre à declaração do Sindicato Rural para comprovar seu tempo de atividade rural - motivo que leva o STR a justificar a "cobrança" da contribuição solidária. No entanto, notou-se que a intermediação do sindicato passa aos aposentados e trabalhadores ativos a impressão de que é o STR que possui um papel relevante na concessão do benefício (e na sua possível cassação), o que confere à diretoria do sindicato um grande poder de pressão sobre sua base, quando, na realidade, é o INSS a instituição com competência legal para conceder e cassar benefícios.

A contribuição solidária vem descontada do benefício previdenciário "aposentadoria descontada" desde a origem do crédito, devido a um acordo entre o Ministério da Previdência e Assistência Social de 1993, que prevê, para aqueles aposentados rurais que consentirem explicitamente o desconto, o recebimento pela Confederação Nacional dos Trabalhadores na Agri-

${ }_{14}$ Acumular a representação de trabalhadores rurais e de produtores familiares cria um potencial de conflitos e contradições internas nos STRs, uma vez que esses grupos de segurados, bem como outros, possuem constelações diferenciadas de interesses, as quais, nem sempre, podem ser atendidas sem conflito por uma única instituição de representação formal. 
cultura (CONTAG) da parcela do benefício correspondente à contribuição de sócio ${ }^{15}$. O valor arrecadado é dividido entre a CONTAG, a Federação Estadual de Trabalhadores na Agricultura e o Sindicato dos Trabalhadores Rurais de filiação do beneficiário na proporção 10\%-30\%-60\% respectivamente.

No caso do município de Igarapé-Açu e de mais alguns da Bragantina, assim como da Microrregião do Salgado Paraense, as lideranças antigas dos STRs, oriundas do período do regime autoritário e da época de implementação do FUNRURAL nos anos setenta, não foram derrotadas e substituídas nos anos 80 e 90 por chapas sindicais ligadas ao sindicalismo da CUT, como aconteceu no resto do Estado (vide Rogge 1996). Curiosamente, é nesses municípios que o volume de arrecadação da contribuição solidária dos beneficiários rurais ao sindicato é extremamente elevada, se comparado com o restante do Estado do Pará, e ele representa a principal fonte de financiamento das atividades do STR. No caso do STR de Igarapé-Açu, por exemplo, conforme declaração da direção do sindicato, a contribuição solidária perfaz cerca de 90\% das receitas. Como o município de Igarapé-Açu sozinho representava cerca de 1/5 do volume de recursos oriundos da arrecadação da contribuição solidária sobre os benefícios rurais no Estado do Pará em maio de 1998, se trata de uma situação excepcional e não representativa da média dos STRs do Pará. Há a possibilidade de que, em alguns municípios do interior do país, os agricultores assinem, no momento em que recebem a declaração comprobatória de tempo de serviço rural, a autorização de desconto da contribuição solidária sem sabê-lo. Ou então, que os STRs utilizem-se de seu poder de pressão sobre os aposentados para fazê-los assinar a autorização de desconto. Esta não é, no entanto, uma prática difundida em todos os municípios brasileiros e, conforme declarações colhidas junto a representantes da FETAGRI/Pará e da CONTAG, não seria a interpretação recomendada e seguida pela maioria das Federações de Trabalhadores na Agricultura e de STRs. Ilegalidades eventuais à parte, o que importa sublinhar mais uma vez é a importância que as aposentadorias rurais assumiram como fonte de financiamento alternativo da estrutura sindical rural no Brasil, onde os segmentos de agricultores familiares ativos não possuem renda monetária constante e regular, com a qual pudesse ser financiada a contribuição, ao contrário dos inativos rurais.

Por fim, dois atores que ainda vale ressaltar são os Correios e os bancos comerciais. As agências dos Correios podem funcionar, devido a um convênio entre o Ministério e a Empresa Brasileira de Correios e Telégrafos, como instância receptora e encaminhadora de pedidos de aposentadoria naqueles municípios em que não há posto de benefícios do INSS. Em 1997, cerca de 4.200 agências dos Correios atuavam nesses serviços em todo Brasil, entre as quais a de Igarapé-Açu. As agências dos bancos comerciais

\footnotetext{
${ }^{15}$ Na Lei 8213/1991 e na regulamentação, está prevista a possibilidade de, mediante autorização do beneficiário e acordo com a respectiva organização, o INSS proceder a desconto de mensalidade ou contribuição do beneficiário para a organização do valor do próprio benefício
} 
funcionam como entidades pagadoras dos benefícios, e a Federação dos Bancos do Brasil (FEBRABAN) conseguiu estabelecer a regra de que naqueles municípios em que houver uma agência bancária, esta possui a prioridade para ser intermediária dos pagamentos previdenciários. Somente se não houver agência bancária é que outras instituições, como por exemplo os Correios, podem assumir essa tarefa, pela qual o INSS paga uma remuneração. Quando existe mais de um banco comercial no município, é no mínimo curiosa a forma de definir-se em que agência bancária um aposentado, que não possua uma conta em algum banco específico (o que é o caso de praticamente todos os aposentados rurais), manterá sua conta. Aparentemente a FEBRABAN teria desenvolvido um método de distribuir de modo regular os aposentados nessa situação entre as agências dos vários bancos no município - o que, por um lado, pode permitir um melhor atendimento individual dos aposentados ao não sobrecarregar determinado banco específico enquanto existem capacidades de atendimento ociosas em outro, mas, por outro lado, distribui a massa de remuneração paga pelo INSS entre os vários bancos e diminui a pressão de competição entre os diversos bancos por clientes aposentados. É possível que, na área rural brasileira, várias agências bancárias somente consigam atingir a rentabilidade necessária para serem mantidas em funcionamento com um mix de produtos oferecidos, entre os quais o pagamento de aposentadorias rurais parece ser um dos mais importantes em termos de retorno financeiro para o banco. Uma cidade do Nordeste Paraense, em que a agência bancária local somente estaria funcionando devido à remuneração oriunda do pagamento de aposentadorias, é o município de Curuçá. A manutenção do funcionamento de uma agência bancária na cidade é de crucial importância para a economia local e de primeiríssimo interesse do Prefeito local, uma vez que, na ausência de agência bancária, o acesso a linhas de crédito subsidiadas para a agricultura, a geração de emprego e o desenvolvimento regional (FNO, FNO-Especial, PROGER, PRONAF, etc.), bem como a própria intermediação financeira entre as empresas locais e a economia nacional, ficam severamente dificultadas, se não comprometidas.

\section{Conclusões e comentários quanto às aposentadorias rurais diante da reforma previdenciária}

A Previdência Rural brasileira custa ao contribuinte previdenciário e fiscal aproximadamente 1,8\% do PIB ao ano, beneficiando direta e indiretamente algo como $18 \%$ da população brasileira com as aposentadorias, pensões e prestações assistenciais e complementares providas no meio rural. A ampla maioria dessas pessoas beneficiadas parece estar entre as mais coerentes do país, seja qual for o padrão de referência adotado. Nesse sentido, uma primeira conclusão a ser traçada a partir dos dados levantados neste texto é que o programa é, para as dimensões que atinge, a cobertura de riscos sociais que promove e a eficiência de "focalização" no combate à 
pobreza, um programa que pode ser considerado muito barato e eficiente, como talvez poucos outros consigam ser no mundo.

Indicou-se, no segmento 2 deste texto, que, entre os casos de sistemas de aposentadorias ou outros benefícios concedidos à população rural de outros países, não há um sequer que tenha logrado a auto-suficiência financeira, porque simplesmente o modelo bismarckiano não é capaz de adaptar-se às características elementares da atividade econômica rural. Por isso, também não há como se esperar que um sistema de previdência rural venha a ser autofinanciável no Brasil, onde é certo que o programa prosseguirá exigindo transferências de recursos, seja de contribuintes previdenciários urbanos, seja do Tesouro Nacional. Aqui, a última fonte pareceria tecnicamente a mais adequada, uma vez que subsidiar o segurado especial rural com recursos de contribuição urbana fará com que os benefícios urbanos percam em qualidade atuarial e tornem-se crescentemente desinteressantes aos segurados normais, minando a sustentabilidade política de longo prazo do sistema previdenciário como um todo. É preciso salientar, ainda, os argumentos que foram levantados ao longo do texto que apontam uma redução gradativa dos gastos com a previdência rural, devido também à tendência iniciada há poucas décadas de redução progressiva da população rural.

Os segmentos 3 e 4 do texto demonstraram as dimensões atingidas pela Previdência Rural, cujo ritmo de expansão, entretanto, tem-se desacelerado a partir de 1994, quando foi completado o ciclo de extensão da nova legislação aprovada por ocasião da Constituição de 1988 e das Leis 8212 e 8213 de 1991. Não há que temer, salvo novas alterações na legislação, novos saltos no número de beneficiários rurais. O que pode ocorrer é que regiões agrícolas recém-ocupadas ou ocupadas nas últimas duas décadas venham a tornar-se regiões nas quais o sistema de previdência rural assuma um papel de destaque como elemento dinamizador da economia local, em especial se os municípios em questão, depois de ocupados, experimentarem um processo de estagnação econômica.

O caso do município de Igarapé-Açu foi objeto de análise do segmento 5 do artigo, no qual fica evidenciado o impacto socioeconômico pronunciado das transferências monetárias efetuadas pelo sistema de Previdência Rural e de benefícios assistenciais no Brasil sobre a renda familiar/domiciliar dos beneficiários, bem como sobre a economia municipal. Constatou-se para Igarapé-Açu que os benefícios atingem principalmente pessoas de poucas posses, em especial os agricultores familiares que, ao longo de sua vida ativa, dificilmente conseguem com a venda de farinha de mandioca aos intermediários de Belém amealhar rendimentos monetários regulares que se equiparem ao valor de um salário mínimo da aposentadoria rural. A percepção de um benefício previdenciário por um ou mais membros da família abre, portanto, novos horizontes socioeconômicos para a unidade produtora familiar rural, em que o valor do benefício serve a diversos propósitos, 
destacando-se, além da garantia da subsistência dos idosos ou inválidos, o de fonte de renda para a família em caso de desemprego de algum dos seus membros ou a de substituto esporádico e precário do modesto sistema de saúde local. Outras funções poderiam ser assumidas pelo benefício rural na família, as quais não foram aqui objeto de investigação ${ }^{16}$.

Na seção 6 apresentou-se o sistema de benefícios previdenciários rurais constituindo uma rede de interesses, a maioria legítimos visando o desenvolvimento municipal (Prefeitura, comércio local) e o fortalecimento da estrutura de representação e de serviços aos trabalhadores rurais ativos e inativos (STRs). É permitido, a partir dos comentários deste segmento e dos dados relatados em partes anteriores deste artigo, concluir que fortes restrições ao sistema no futuro prejudicarão a viabilidade financeira de instituições importantes de apoio aos trabalhadores rurais, em áreas em que determinados serviços públicos são prestados de forma por vezes precária (saúde) ou mesmo são inexistentes (seguro-desemprego). É possível que restringir o sistema de previdência rural diminua a tendência dos aposentados a permanecer no campo ou em um espaço micro-urbano, forçando-os a optar por migrar para centros urbanos maiores, eventualmente acompanhados de familiares em busca de infra-estrutura de apoio. A economia fiscal que uma reforma pouco ponderada do sistema de previdência rural pode gerar muito provavelmente será compensada com a necessidade de adicionais de despesas públicas em outras rubricas, nos centros urbanos de destino das migrações que eventualmente poderiam ser geradas. Por isso, é recomendável ter-se cuidado ao reformar o sistema - que tem certamente prestado ao Brasil mais serviços do que muitas vezes é afirmado.

\section{Agradecimentos}

Agradeço aos colegas dos Projetos Shift ENV 25 e 44, de Belém, Göttingen, Bonn, Berlim e Igarapé-Açu, sem cuja experiência prévia acumulada a pesquisa teria sido muito difícil. Um destaque e agradecimento muito especial deve ser dado aos colaboradores diretos do Projeto Shift ENV 44 em Belém e Berlim - Prof. Manfred Nitsch (coordenador da parte alemã), Prof. Francisco de Assis Costa (coordenador da parte brasileira), Prof. Thomas Hurtienne e os colegas pós-graduandos Albrecht Kasper, Francisco Romualdo Filho, Frederico Caeté e Alcindo Wander. Além disso, agradeço aos pela gentileza e desprendimento aos responsáveis e funcionários dos vários órgãos governamentais inquiridos - abarcando a SPS/CGEA e SPS/CGEPSE do Ministério da Previdência e Assistência Social (Brasília), as Superintendências Regionais de DATAPREV e INSS (em especial a Gerência do Seguro

\footnotetext{
${ }^{16}$ Por exemplo: a declaração de um entrevistado em Igarapé-Açu, dizendo »Minha plantação o rio pode levar, minha aposentadoria não« abre a hipótese de que a Previdência Rural seja um substituto do seguro agrícola, hipótese levantada pelos colegas do projeto IPEA-IPARDES-FUNDAJ.
} 
Social) no Pará, o IDESP, a SEFAZ e a SEPLAN (órgãos do Governo do Estado do Pará, em Belém), os colegas da SUDAM (Belém), bem como a direção do Posto de Benefícios do INSS em Castanhal (PA). Todas essas instituições apoiaram a pesquisa com o fornecimento de dados e muitas sugestões, repartindo conhecimentos que se mostraram essenciais. Além disso, há que mencionar, agradecido, o apoio da FETAGRI (Belém) e CONTAG (Brasília). Em Igarapé-Açu também existem diversas dívidas de gratidão: pedindo antecipadamente perdão por omissões involuntárias, quero salientar no mínimo as diretorias do Sindicato de Trabalhadores Rurais, do de Empregadores Rurais, da Secretaria de Promoção Social da Prefeitura Municipal e os nomes de Lucineide, Plácido e Marcela como pessoas, cujo auxílio foi inestimável. Por fim, agradeço a ajuda de Guilherme Delgado e de sua equipe do IPEA-IPARDES-FUNDAJ (Brasília-Curitiba-Recife), bem como de Christine Viveka (IPEA-Brasília), foi crucial. Os colegas mencionados compartilharam desprendidamente comigo informações, métodos, conteúdos e prognósticos sobre resultados esperados de suas próprias pesquisas em andamento sobre o sistema de previdência rural no Brasil e apoiaram-me, ademais, com fundamentadas críticas e sugestões nas várias fases de elaboração do trabalho e em dois seminários internos. A todos, muito obrigado. Entretanto, os equívocos cometidos e as opiniões emitidas neste trabalho são de responsabilidade exclusiva do autor. 


\section{Referências bibliográficas}

ALMEIDA, Célia Maria. Política Social e Assistência Médica aos Trabalhadores Rurais: Um Estudo sobre o FUNRURAL. Rio de Janeiro: Dissertação de Mestrado submetida ao Instituto de Medicina Social/Universidade Estadual do Rio de Janeiro.

ANSeS - Administración Nacional de la Seguridad Social. Ministerio de Trabajo y Seguridad Social/SPS/ANSeS. Cambiar para Servir a la Gente. Buenos Aires: (s.d.-a).

ANSeS - Administración Nacional de la Seguridad Social. Ministerio de Trabajo y Seguridad Social/SPS/ANSeS. Guía de la Seguridad Social - 1. Jubilaciones. Buenos Aires: (s.d.-b).

ARAGÓN CLÉRIGO, Alicia. Einführung in die Zona Bragantina. In: KASPER, Albrecht et al. (Ed.). Stadt und Land - Entwicklung im Nordosten von Pará. Berichte und Bilder der LAI-Amazonien-Exkursion 1996. Berlin: Freie Universität Berlin/Lateinamerika-Institut, 1996

ARAPIRACA DA SILVA, A. et al. A Historical Dynamics of Reproduction of Agriculture in Igarapé-Açu (Northeast of the State of Pará): A Study Focusing on Agrarian Systems. In: LIEBEREI/BIANCHI/VOB (ORGS.). Proceedings of the Third SHIFT Workshop (Manaus). Geesthacht.

BENIO, Marek; MLYNARCZYK-MISIUDA, Jolanta (1997). Country Report Poland.[The Welfare System in Poland.] In: EMERGO, v. 4, n 2, p. Spring 97.

Bundesministerium für Ernährung, Landwirtschaft und Forsten - BMELF [Ministério Federal da Alimentação, Agricultura e Florestas] (1998). Soziale Sicherheit für die Landwirtschaft. [Segurança Social para a Agricultura.] Bonn: BMELF.

CORADINI, Odaci L. (s.d.). As Políticas de Saúde e Previdência Social Rural. Tempo e Presença, n. 257, ano 13.

COSTA, Francisco de Assis (1989). Amazonien - Bauern, Märkte und Kapitalakkumulation. [Amazônia - Camponeses, Mercados e Acumulação de Capital.] Saarbrücken, Fort Lauderdale: Breitenbach.

DAIN, Sulamis (1988). Crise Fiscal e Dilema Distributivo. Rio de Janeiro: mimeo, Tese de Prof. Titular na UFRJ.

DELGADO, Guilherme (1994). Agricultura e Comércio Exterior: Rumo da Regulação Estatal e suas Implicações para a Segurança Alimentar. Cadernos Temáticos do Fórum Alternativas para a Agricultura Brasileira. Rio de Janeiro: Rede Interamericana Agricultura e Democracia.

(1997). Previdência Rural: Relatório de Avaliação Socioeconômica. Texto de Discussão 477. Brasília: IPEA.

et. al. (1998). Avaliação da Previdência Social Rural. Relatório metodológico. Brasília: IPEA, mimeo. 
Departamento de Estudos Sócio-Econômicos Rurais/DESER (1998). Para Entender a Previdência Social na Área Rural. Curitiba: DESER.

FOSTER, J.; Greer, E.; Thorbecke, E. (1984). A class of decomposable poverty measures. Econometrics, v.52, 1984.

GOLINOWSKA, Stanislawa; Czepulis-Rutkowska, Zofia; Szczur, Maria (1997). The Case of Poland. In: Augustinovics, Mária et. al. (Orgs.) Pension Systems and Reforms - Britain, Hungary, Italy, Poland, Sweden. Phare ACE Research Project P95-2139-R. Final Report. Budapest: PHARE.

HURTIENNE, Thomas (1999). Ecologia tropical e agricultura familiar na Amazônia Oriental. Uma comparação dos resultados da pesquisa socioeconômica sobre fronteiras agrárias sob condições históricas e agroecológicas diversas. Belém: UFPA, mimeo.

Instituto Brasileiro de Geografia e Estatística/IBGE (1991). Censo Demográfico 1991. Resultados do Universo Relativos às Características da População e dos Domicílios. N 7, Pará. Rio de Janeiro: IBGE. (1996). Sindicatos: Indicadores Sociais. Rio de Janeiro: IBGE.

KAGEYAMA, Ângela; Graziano da Silva, José (1993). Previdência Social Rural: Avanços e Recuos. Conjuntura Social, n 4-5. Brasília: Ministério da Previdência Social.

KUMMER, Sirlene (1999). Peasant's Youth Between Tradition and Modernity. Göttingen: Tese de Mestrado junto à Universidade de Göttingen.

MAIA GOMES, GUSTAVO; MCDOWELL, MARIA CRISTINA (1997). Transferências de Renda para as Famílias: Estimativas em Nível de Municípios, 1995. Relatório do Projeto MPAS-FADE-IPEA n 70/96. Brasília: IPEA.

MAIA GOMES, GUSTAVO; VERGOLINO, JOSÉ RAIMUNDO (1997). Trinta $e$ cinco anos de crescimento econômico na Amazônia (1960/1995). Texto de discussão 533. Brasília: IPEA.

MALLOY, James M. (1976). Authoritarianism and the Extension of Social Security Protection to the Rural Sector in Brazil. Pittsburgh: mimeo.

(1979). The Politics of Social Security in Brazil. Pittsburgh: University of Pittsburgh Press/Pitt Latin American Series.

; Parodi, Carlos A. (1993). Politics, Equity and Social Security in Brazil: A Case Study of Statecraft and Citizenship, 1965-1985. Abel, Christopher; Lewis, Colin M. (Orgs.). Welfare, Poverty and Development in Latin America. Basingstoke: McMillan/St. Antony's.

MARIN, Rosa Elizabeth; Guerra, Gutemberg (1995). Trabalhadores Rurais: A Cidadania via Seguridade Social. Anais do XVII Encontro Nacional da Associação PIPSA (Projeto de Intercâmbio de Pesquisa Social em Agricultura), v. 2. Porto Alegre: IFCH/Universidade Federal do Rio Grande do Sul. 
MELO, Marcus André B.C. (1993). Anatomia do Fracasso: Intermediação de Interesses e a Reforma das Políticas Sociais na Nova República. Dados Revista de Ciências Sociais, v. 36, $\mathrm{n}^{\circ} 1$.

MESA-LAGO, Carmelo (1978). Social Security in Latin America: Pressure Groups, Stratification, and Inequality. Pitt Latin American Series. Pittsburgh: University of Pittsburgh Press.

(1993). Instituto Ecuatoriano de Seguridad Social. Evaluación Económica y Opciones para Reforma. Quito: INCAE.

(1994). Changing Social Security in Latin America. Toward Alleviating the Social Costs of Economic Reform. Boulder, Colo.: Lyenne Rienner.

Ministério da Previdência e Assistência Social/MPAS; INSS; DATAPREV (1998). Sistema de Legislação, Jurisprudência e Pareceres da Previdência e Assistência Social - SISLEX (CD-ROM). São Paulo: Microservice Microfilmagens e Reproduções Técnicas. Também na Internet: http:// www.mpas.gov.br.

MONTEIRO NETO, ARISTIDES; MCDOWELL, MARIA CRISTINA (1998). A Ação do Governo Federal como Transferidor de Renda às Famílias no Nordeste, 1995. Revista Econômica do Nordeste, v. 29, número especial. Fortaleza: Banco do Nordeste do Brasil.

NITSCH, Manfred (1980). Social Policy Measures and the Distribution of Wealth and Income - as Exemplified by Brazil. Economics, v. 21. Tübingen: Institute for Scientific Cooperation.

(1984). What Interests Lie Behind Research into Social Security and Social Law in the Developing Countries? Law and State, v. 30. Tübingen: Institute for Scientific Cooperation.

(1997). Dimensionen von Sozialversicherungsreformen. Lateinamerika, Deutschland und darüber hinaus. [Dimensões de Reformas Previdenciárias. América Latina, Alemanha e Além.] Lateinamerika Analysen-Daten-Dokumentation 36. Rentenreformen in Lateinamerika Lehren für Europa [Reformas Previdenciárias na América Latina - Lições para a Europa]. Hamburg: Institut für Iberoamerika-Kunde IIK.

OLIVEIRA, Fabrício A. (1995). Crise, Reforma e Desordem do Sistema Tributário Nacional. Campinas: Editora da UNICAMP.

OLIVEIRA, Francisco Eduardo Barreto; Bevilaqua, Afonso S. (s.d.). Um Diagnóstico da Previdência e Assistência Social Rural. s.l., mimeo.

PNUD/IPEA/IBGE/Fundação João Pinheiro (1998a). Atlas do desenvolvimento humano no Brasil. Projeto »Desenvolvimento Humano no Brasil« (BRA/ 97/007). Brasília, Rio de Janeiro, Belo Horizonte: Versão em CD-ROM. (1998b). Desenvolvimento humano e condições de vida: Indicadores brasileiros. Projeto »Desenvolvimento Humano no Brasil« (BRA/97/007). Brasília: PNUD/IPEA/IBGE/FJP. 
ROGGE, Jan (1996). Die Kleinbauernbewegung im Nordosten Parás (Brasilien): Geschichte, Selbstverständnis und ökologischer Diskurs. Berlim: Dissertação de Mestrado submetida ao Lateinamerika-Institut da FU Berlin. Publicada na Alemanha com mesmo título em 1998 em Mettingen: Brasilienkunde-Verlag (Aspekte der Brasilienkunde Nr. 18). Versão em português disponível como: Rogge, Jan (1996). Ascensão do Sindicalismo Rural no Nordeste Paraense: Movimento Novo, Estruturas Velhas. Belém: UFPA/NAEA.

SANTANA, A. (1990). Diagnóstico sócio-econômico da pequena agricultura de Igarapé-Açu. Belém: Faculdade de Ciências Agrárias do Paraná (FCAP).

(1997). Reestruturação Produtiva e Desenvolvimento na Amazônia. Belém: BASA/FECAP.

SAWYER, Donald (1979). Colonização da Amazônia: Migração de nordestinos para uma frente agrícola no Pará. Revista Econômica do Nordeste, v. $10, \mathrm{~N}^{\circ} 3$, p. 773-812.

SCHWARZ, Manfred (1980). Social Security in Brazil: A Welfare Policy Based on the Payroll. Campinas: Cartograf. Coleção ILDES.

SCHWARZER, Helmut (1997). Los Sistemas de Jubilaciones en América Latina. Orígines, Crisis y Modelos de Reforma. Desarrollo y Cooperación, N 1/1997. Berlin: Deutsche Stiftung für Internationale Entwicklung DSE.

(1997). Alterssicherung in Brasilien: Probleme und Reformperspektiven. [Proteção à Velhice no Brasil. Problemas e Perspectivas de Reforma.] Lateinamerika Analysen-Daten-Dokumentation -36. Rentenreformen in Lateinamerika - Lehren für Europa [Reformas Previdenciárias na América Latina - Lições para a Europa]. Hamburg: Institut für Iberoamerika-Kunde IIK.

Universidade Estadual de Campinas/UNICAMP (1993). Impactos sobre a Economia Rural da Lei 8212. Relatório Final. Projeto de Pesquisa A Previdência Social e o Setor Rural. Campinas: UNICAMP-Secretaria Nacional de Previdência Social.

WANDER, Alcido (1998). Die sozioökonomische Bedeutung des Maracujaanbaus für kleinbäuerliche Gemischtbetriebe im östlichen Amazonasgebiet. [A significância sócio-econômica do cultivo de maracujá para a pequena produção agrícola mista na Amazônia oriental.] Göttingen: Tese de Mestrado junto à Universidade de Göttingen. 


\section{Lista de Siglas}

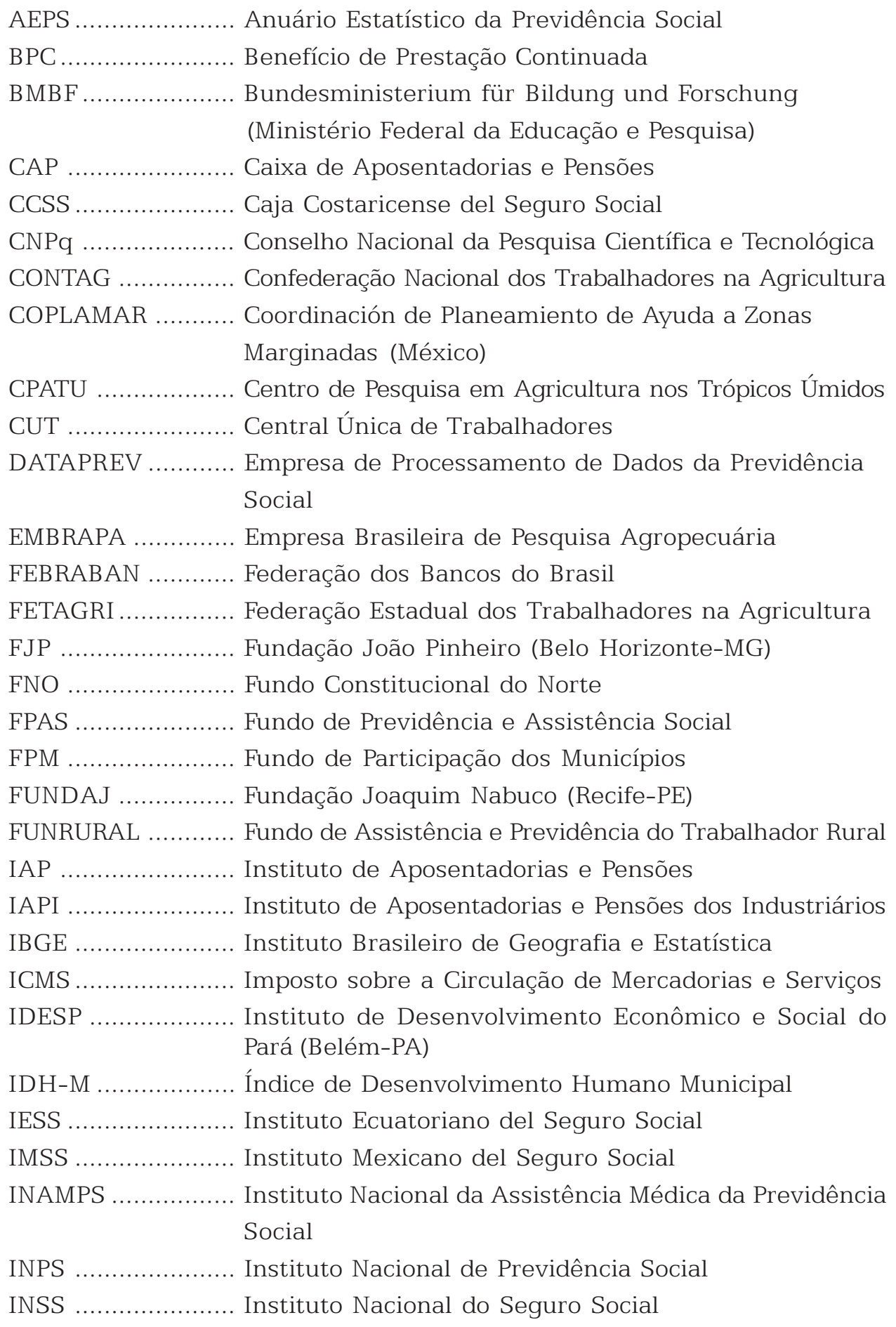


IPARDES Instituto Paranaense de Desenvolvimento Econômico e Social (Curitiba-PR)

IPEA Instituto de Pesquisa Econômica Aplicada (Brasília-DF e Rio de Janeiro-RJ)

IPTU Imposto Predial e Territorial Urbano

KRUS Kasa Rolniczego Ubezpieczenia Spolecznego (Fundo Polonês de Previdência Rural)

LAI/FU Berlin ........ Lateinamerika-Institut/Freie Universität Berlin LOAS Lei Orgânica da Assistência Social

MPAS/SPS/CGEA ... Ministério da Previdência Social/Secretaria de Previdência Social/Coordenação Geral de Estatística e Atuária

MPAS/SPS/CGEPSE . Ministério da Previdência Social/Secretaria de Previdência Social/Coordenação Geral de Estudos Previdenciários e Sócio-Econômicos

NAEA/UFPA ........... Núcleo de Altos Estudos Amazônicos/Universidade Federal do Pará

OIT Organização Internacional do Trabalho

PCV Pesquisa de Condições de Vida

PIB Produto Interno Bruto

PNAD Pesquisa Nacional por Amostra de Domicílios

PNUD Programa das Nações Unidas para o Desenvolvimento PPD Pessoa Portadora de Deficiência

PPV Pesquisa de Padrões de Vida

PROGER Programa de Geração de Emprego e Renda

PRONAF Programa Nacional de Apoio à Agricultura Familiar

PRORURAL Programa de Assistência ao Trabalhador Rural

RAIS Relação Anual de Informações Sociais

RMV Renda Mensal Vitalícia

SEFAZ/PA Secretaria de Estado da Fazenda/Estado do Pará

SEPLAN/PA Secretaria de Estado do Planejamento/Estado do Pará SHIFT Studies of Human Impacto on Forests and Floodplains in the Tropics

SINPAS Sistema Nacional de Previdência e Assistência Social

STR Sindicato de Trabalhadores Rurais

SUDAM Superintendência para o Desenvolvimento da Amazônia ZUS Zaklad Ubezpieczen Spolecznych (Instituto do Seguro Social Polonês) 